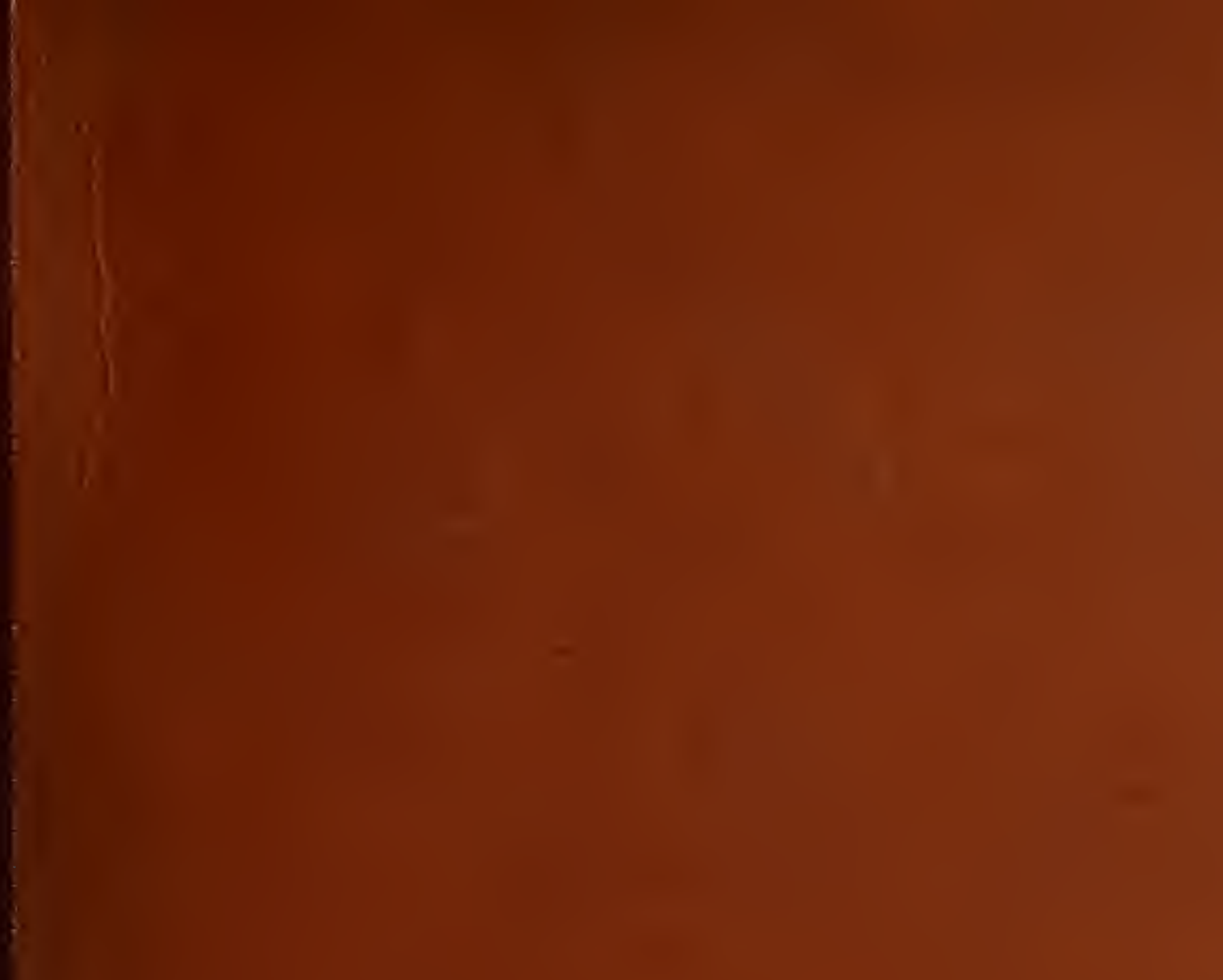

$$
\text { , }
$$




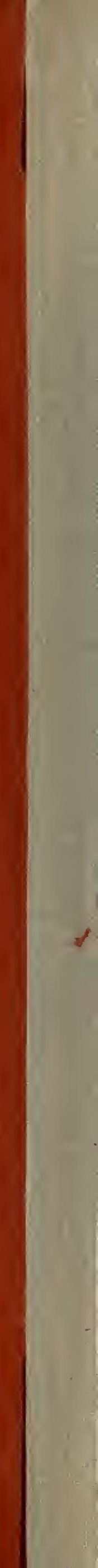





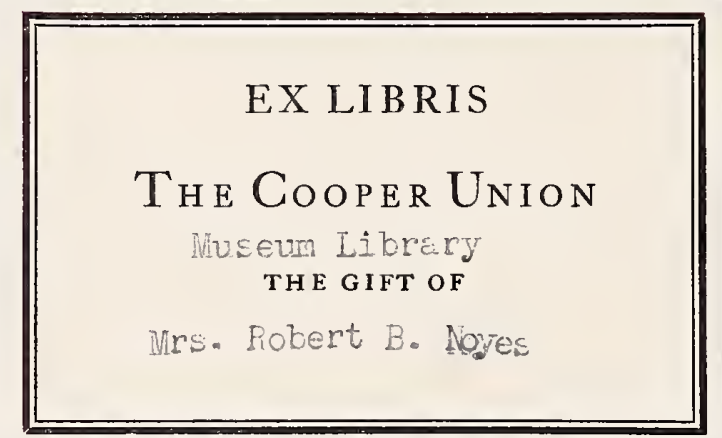




\title{
WEST INDIAN BOOKPLATES
}

\author{
BEING A FIRS'T LIST OF PLATES RELATING \\ TO THOSE ISLANDS.
}

COMPILED BY

VERE LANGFORD OLIVER, M.R.C.S., \&c.

Reprinted from "Caribbeana."

LONDON :

MITCHELL HUGHES AND CLARKE, 140 WARDOUR STREET, W. 1914. 
$Z_{994}$

W4OC

1914

Rosernild

colly 



\section{ฐ)amaícam bookplates.}

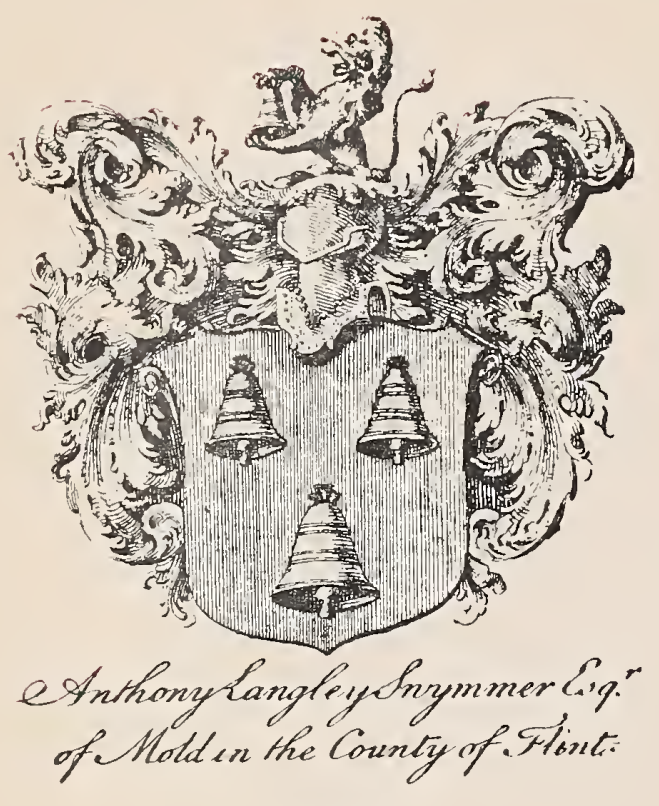

No. 531.

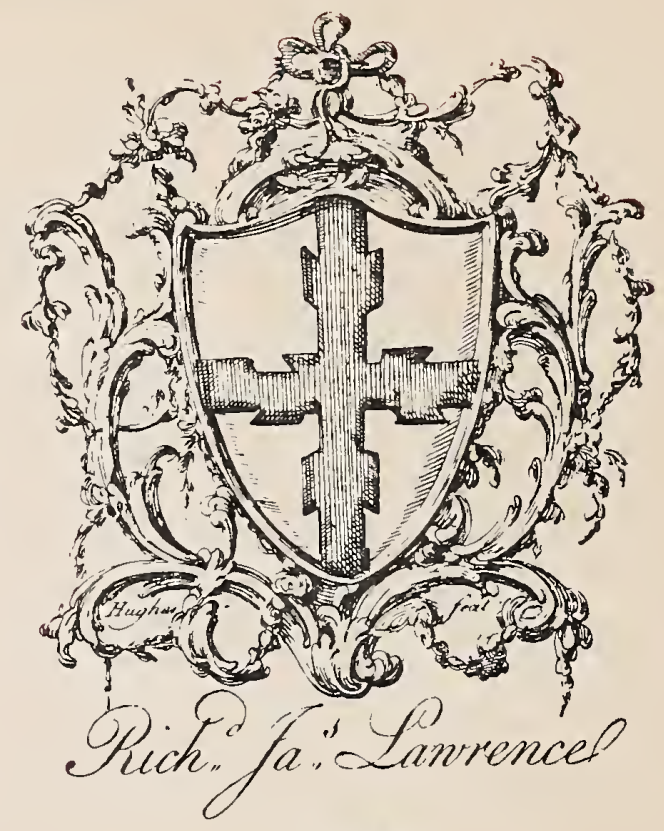

No. 444.

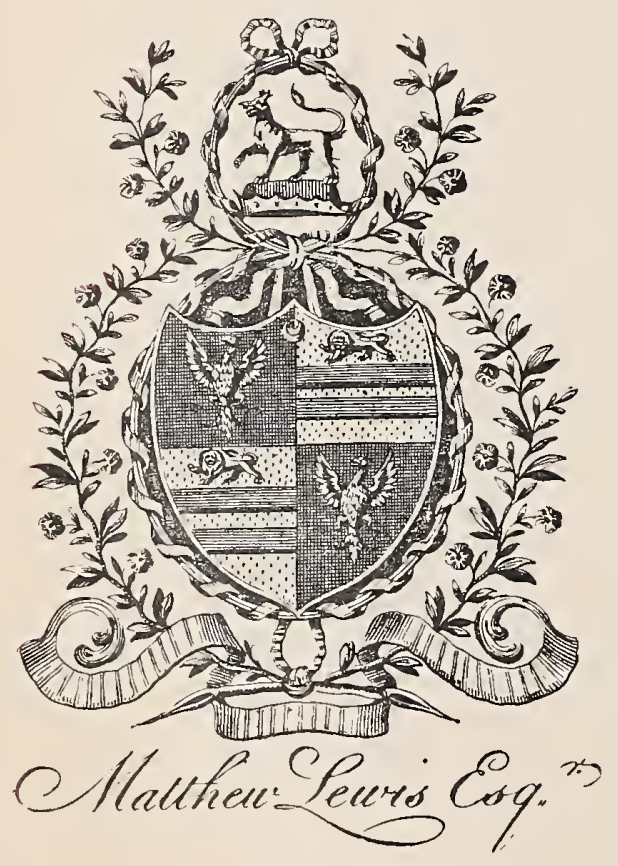

No. 453.

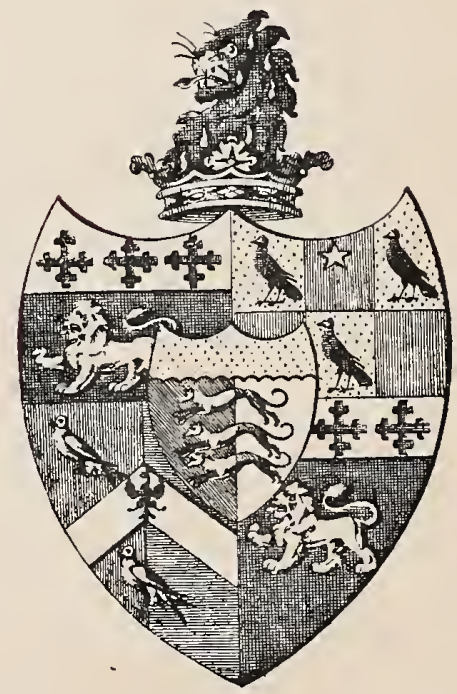

Edwarutiscestonfong

No. 461. 


\section{WEST INDIAN BOOKPLATES.}

On 8 March 1912, Mr. W. E. Baillie of Bridgeport, Conn., U.S.A., wrote that he had for twenty years been interested in West Indian bookplates, that he had just returned from a visit to Jamaica, but had not been able to add to his collection during his tour in the W.I.

He then forwarded a list of his plates, and put me into communication with Mr. F. Cattle of Heanor, Derbyshire, who has a very large collection, more especially of Chippendale examples.

Mr. Cattle then obtained a list from Mr. Frank Marshall of Philadelphia, U.S.A.

I then examined the Franks Collection at the British Museum, and the various printed authorities, and with the assistance of Mr. Cattle, who from time to time supplied notes of many rare plates, the following list has been compiled. It is not, of course, complete, as without good pedigrees it is very difficult to identify anonymous plates, but I hope that additions may be supplied when the subject becomes better known.

The blazon may be occasionally faulty, but it is that of an amateur and not of an expert in heraldry.

The following abbreviations are used:-

$$
\begin{aligned}
& \text { F. = Sir A. Franks' Collection. } \\
& \text { W.E.B.= W. E. Baillie. } \\
& \text { F.C. = Frederic Cattle. } \\
& \text { F.M. = Frank Evans Marshall of Philadelphia. } \\
& \text { J.M. = Julian Marshall sale catalogue. } \\
& \text { E.L.J. = Ex Libris Journal. } \\
& \text { A. = Antigua, or History of Antigua. } \\
& \text { M. of C. = Member of H. M. Council. } \\
& \text { D.N.B. = Dictionary of National Biography. } \\
& \text { Arm. = Armorial. }
\end{aligned}
$$

EDrтoR.

\section{Antígua.}

1. "JAs Makimtrick Adair, D.D." Arm. spade shield on a mantle. (F., 103.) ARMs.-Per bend Argent and Or, three dexter hands couped.

CREST.-A man's head couped and transfixed by a spear. MotTo. -I DARE.

James Makittrick, a native of Inverness, born 1728, settled in Antigua about 1750, where his first wife Agnes died 1753. He was licensed 1754; mar. secondly about 1755 Anne Barter, and left in 1765; M.D. Edin. 1766; assumed the name of Adair 1783 ; wrote medical works and a defence of slave-owners, and is said to have died at Harrogate 24 April 1802 ("D.N.B."), but his will was proved in 1801.

His son, Dr. James Barter Makittrick Adair, died shortly before him. 
2. “J. P. Anderidon 1773." Printed label. (J.M.)

3. "John Proctor Anderdon." Arm. (F., 466.)

ArMs.-Quarterly: 1 and 4, Sable, two shackbolts and a double one; 2, Or, three nails [Рвостов]; 3, Sable, an cstoile of six points between two flaunches Ermine [Новатт]. On an escutcheon of pretence: Ermine, on a chief Sable three lions rampant Argent [OLIVER].

Son of Ferdinando Anderdon by Mary Hobart, and grandsón of Dr. John Anderdon of Bridgewater, co. Somerset, by Mary Proctor; mar. first in 1785 Anne, eldest dau. and coheiress of Tho. Oliver, Lieut.-Governor of Mass., and Bristol, and died 1847, aged 87. F. 464 may be the grandfather's.

4. "John L. Anderdon." Arm. (F., 465.)

Arms of Anderdon quartering Oliver and impaling: Quarterly, Azure and Gules, a cross flory between four trefoits [MaNNang].

Crest. - An arm in armour embowed, couped. Мотto.-Fortitedine.

John Lavicount Anderdon, third son of the preceding, born 1792, of Chislehurst, W.I. merchant, mar. 1816 Anna-Maria, dau. of Wm. Manuing, M.P., of St. Kitts and London, and died 1874.

5. "SAMUEI Athill EsQB." Arm., about 1800.

ARMs.-Argent, on a chevron Sable three crescents Or. On an escutcheon of pretence: Argent, a chevron Gules between three trefoils of the field (L $\mathrm{TNCH}$ ).

Crest.-A crescent Or. Motтo as above. (F.C.)

Dr. Samuel Byam Athill, sometime President, born 1758, mar. 1780 Mary, dau. and heiress of Nich. Lynch, and died 1832.

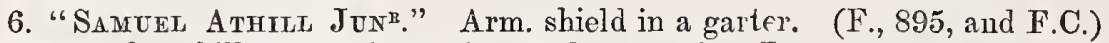

Arms of Athill quartering: Quarterly, 1 and 1, LYNCH; 2 and 3, Gules, a chevron Argent between three spear-heads [? CouIIns]. Mотто as above.

Son of the preceding, born 1786, barrister, and died 1811.

7. "James Athild." Festoon, arm. About 1780.

ARMs.-Argent, on a chevron Sable three crescents of the first.

CREST.-A dexter arm in armour embowed, couped, holding a falchion.

Motto.-Crescam ut prosim. (F.C.)

Physician and Chief Justice, Speaker, M. of C. 1803; born 1759 and died 1822.

8. "Отто BА ̈̈еR." Crest. (F., 1840.)

CREsT. $-A$ demi-lion rampant, couped, the tail incurved, in its dexter paw a pine-apple. The design looks foreign.

9. "Јонn Отто BaxJer EsQR." Chip. Crest. (F., 1839.)

Crest as abore, but the tail not incurved. Motto.-Mand Fortx.

Illustrated ante, II., 289. Two cousins of this name died, the one in 1790 , and the other in 1817 .

10. "Rowland Blackanan of the Mrddee Temple Esq." Jac. arm. (F., 2700. Illustrated in A., iii., 412.)

ARMs.- Ermines, three lions rampant. Crest.-A demi-griffin.

Born 1705, mar. Priscilla, dau. of Rob. Warren, M.D., of Barbados, and died 1780 .

11. "JNo Lucte Btackman." Arm. spade shield, about 1790.

ARMs.- Ermines, three lions rampant Or, within a bordure of the second.

Crest as abore. Motto.- PERSEvere. (F.C.)

Born in Barbados 1735, nephew of the preceding, of London, merchant, mar. Mary Harnage, and died 1797. 
12. "Miss Anva Maria Buackman. (J. Brooke, fecit, Fetter Lane.)"

Chip. pict. arm., lozenge. (F., 2698. Illustrated in E.L.J., vi., 155.)

Engraved about 1770 (Fincham).

ARMs. - Ermine [sic], etc. She was a dau. of Rowland B.

13. "Marguerite Wingfiemd Bonnin." Arms in a garter. On blue paper. Spinster. (F., 3037 and E.L.J., vi., 119.)

ARMs.-Quarterly: 1 and 4, Argent, four crosses; 2 and 3, Azure, a lion rampant.

Crest.-A demi-lion rampant, couped, charged with a cross, in its paws some rushes (?). MotTo.-SPES DABIT AUXILIUM.

Perhaps of the Huguenot family in A., of whom Henry Gousse Bonnin died 1778.

14. "Francisci Bram Ex Insula Antigua." Jac. arm. in sepia. (F., 4715, Allen, 122 ; F.C. has an impression in black.)

AnMrs.- Argent, three dragons' heads erased, each holding in its mouth a dexter hand couped. Motro.-ClarIs Dextera FaCtIS. No crest.

Born 1709, mar. 1738 Jane Warner, and died 1757.

15. "SAML Bтам." Chip. arm. (F., 4720.)

Arms and Crest of Byam.

16. "Samuer Byam." Chip. arm. (Stephens; F., 4721.)

ArMs.-Quarterly: 1 and 4, BraM; 2, Argent, three Catherine wheels Sable, within a bordure engrailed Gules [Scotr]; 3, Or, a bend engrailed between six roses [WARNer]. Crest of Byam.

Born 1712, mar. 1735 Grace, dau. and coheiress of Col. Edw. Warner, by Eliz., dau. and heiress of Richard Scott of Barbados, and died 1738. Their son Sam. born 1737 , and died 1761, was the owner of this plate.

17. "Enward Byam." Chip. arm. (F., 4714.) Copied from No. 4721, and the Motto added.

Born 1712, of Cedar Hill, mar. 1734 Lydia, dau. of Gov. Edw. Byam, and died 1768.

18. "George Bram, EsQR." Chip. arm. (F., 4716.)

Arms, Crest, and Motto of Byam.

Bap. 1734, of Apps Court, co. Surrey, mar. Louisa Bathurst, and died 1779.

19. "Mar'TIN Byam EsQR"." Chip. pict. arm. (F., 4717. Illustrated by F.C. in E.L.J., xviii., 84.)

Arms and Crest of Byam.

Born 1742, M. of C., mar. 1775 Eliz. Blizard, and died 1805. 4722.)

20. "Samuer Bram." Wreath and ribbon, arms in a beaded oval. (F., Arms and Crest of Byam.

21. "Samuel Bram D.D." The last plate with "D.D." added. (F., 4723.)

Bap. 1769, D.D. 1807, Chaplain to Geo. III., mar. 1802 Jane Akers Welsh of St. Kitts, and died 1816.

22. "R Rurgh Bram. Kings Coll. Cam." Arm.

ARus.-Vert, a chevron Or between three dragons' heads erased.

Crest of Byam. (Not in F. My plate.) 
23. "Richo Burgh Bram. Kings Coll. Camis." Arm.

AnMs.-Quarterly: 1 and 6, Argent, three dragons' heads erased vert, ete.; 2, Caradoc Traich-Tras; 3 , Elystan Glodrydd ; 4, Powel, Prince of Caerleon; 5, Elvarch, Lord of Penrose and Brythlyn. (F., 4718.)

Crest and Motto of Byam.

24. "The Revi Richard Burgh Bram." Arm. Engraved by Appleby for Burke's Heraldic Illustrations. (F., 4719.)

Arms, Crest, and Motto as in preceding.

Born 1785, B.A. 1808, M. of C., Vicar of Kew and Petersham, co. Surrey, mar. 1805 Frances Watkins, and died 1867.

25. "Anonymous." Crest. (F., 33,142.)

CREst.-A dragon's head erased holding a bleeding hand in its mouth. This is evidently the Crest of Byam.

26. "Charlton Wollaston." Chip. arm. (F., 32,333.)

Arus.-Argent, three mullets pierced Sable, a crescent for a difference. Sable.

CREST.-Ont of a mural crown a demi-griffin segreant holding a mullet pierced

Born 1733, M.D. Cam. 1758, Physician to Guy's Hospital, F.R.S. (Munk II., 229), mar. 1758 Phillis, only dau. and heiress of Sam. Byain by Grace Warner, and died 1764 .

27. "Charlton Bram Wollaston." Arm. spade shield. (F., 32,334.)

Arms and Crest of W. MotTo.-NE QUTD FALsI. $18 \pm 0$.

Son of the preceding, born 1765, Recorder of Dorchester, Dorset, and died.

28. "Collonel Christopher Codrington / one of the captains in his Maties | First Regiment of Foot Guards." Early arm. (F.,* 393.)

CREST.-Out of a coronet a dragon's head between its two wings.

ARMs.-Argent, on a fess embattled and counter-embattled Sable, a cottise dancetty Or, between three lions passant Gu.

Born 1668 in Barbados, B.A. Oxford 1691, Governor of Leeward Islands 169S1703, Founder of Codrington College, and died 1710. All Souls' College, Oxford, having received 10,000l. from him, used a bookplate impaling his arms. (E.L.J., ix., 21.)

29. "S $\mathrm{S}^{\mathrm{B}}$ Will Codrington Bari ${ }^{\mathrm{T}}$." Chip. arm. (F., 6288.)

Arms.-Quarterly : 1 and 4, Argent, a fess embattled and counter-embattled between three lions passant Sable; 2 and 3, Vert, on a bend Or three roses Gules, in sinister point of chief a dexter hand [CoDRIngton of Wapley]. In centre point of shield the badge of Ulster.

Crest of Codrington as above.

Born 1719, succeeded his father as 2nd Bart. 1738, and died 1792.

30. "EDw Codrington." Chip. arm. (F., 6284.)

Arms and Crest of Codrington as in No. 6288, but the wings of Crest checky Azure and Ermine.

31. "Enw" Codrington." Arm. spade shield in garter. (F., 6285.)

Crest and Arms as in No. 6288, but the fess Gules and a mullet for a difference.

Probably father of Chr. Bethell Codrington, born 1732, mar. 1759 Rebecca Lesturgeon, and died 1775. 
32. "Str C Betuell Codringtox, Bart." Arm. (F., 62S2.)

Arms.-Quarterly: 1 and 4, Codrington, but the fess Gules; 2 and 3, Argent, on a chevron Sable, between three boars' heads couped, an estoile [BETIILL]; quartering Codrington of Wapley, and impaling: Argent, a fess engrailed between three cinquefoils, all within a bordure Sable [FOLET].

Crests.-1, Codringtox; 2, Between its troo wings an eagle's head couped, charged with an estoile Or. MOTTO.-IMMERSIBILIS EST VERA VIRTUS.

Chr. B. Codrington, born 1764, assumed the name of Bethell 1797, mar. 1796 Lady Caroline Foley, claimed the baronetcy 1816, and died 18t3. His grandmother was Eliz. Bethell. The Editor of the "Franks" catalogue has mistaken Codrington of Wapley for Bates.

33. "Sir C. Bethell-Codringroy Bart." Arm. The last plate with a hyphen added. (F., 6283.)

34. "Admirat Sir Euward Codrington." Arm. Supporters. (F., 6286.)

Arms of Codrington the fess Gules, with various augmentations as given in Burke"s "Armory."

Born 1770, G.C.B. 1827, mar. 1802 Jane Hall, and died 1851.

35. "H. J. Codrington." Crest.

The augmented Crest of his father the preceding. Henry John, a Capt. R.N., was the third son.

36. "W. J. Connington." Wreath and ribbon arm. (F., 6287.)

Arms of Codrington, the fess Gules and a martlet for a difference, quartering Codrington of Wapley. Crest of Codrington.

37. (Codrington). Anonrmous. Arm. (F., 6289.)

ArMs.-Quarterly: 1 and 4, Argent, a fess Sable between three lions passant Gules, a crescent for a difference; 2 and 3 , Codringron of Wapley.

Crest of Codrington, with wings Chequy Azure and Or.

MotTo.-vera VIRTes iMIMERSABILIs.

Another plate "RichD ChUte Codrington, Roc sc. Camb." has the above coats (F.C.) but it does not appear to belong to the Antiguan branch.

35. "Nathaniel CRUmp." Chip. engraved label. (F., 7506.)

Of Cocoa Nint Hall, and of Marylebone 1769-1771.

39. (Donovar). Anonrmous. (F., 8868.)

CRest.-An eagle with wings expanded.

Arus.- $A$ dexter hand vested and cuffed, holding a sword palewise entwined with a serpent [DoxoraN]; impaling: Quarterly, 1, Azuve, a fess Or, in chief two mullets of the last [YATE]; 2, Azure, a chevron between three annulets $O$ r [Dobrss]; 3, Gules, a cheoron Argent between ten crosses pattée, six above, four below [Berketer] ; 4, Gules, a stag's head cabossed [Box]. See several DobynsYate plates and pedigree in Burke's "Landed Gentry," and Visitation of co. Gloucester 1682-3.

Richard Donovan of A., and of Tibberton Court, co. Gloucester, entered Gray's Inn 1790, mar. 1797 Caroline Eliz. Dobyns-Yate, and died at A. 1816. Nos. 8865 and 8867 have the above coat of Donovan.

40. "His Exceluefcy Walter Douglas Esq ${ }^{R}$ Cap'. General and CheifGoteryor of all the Leeward-Caribbee-Isuands iN Ajerica; \& Vice AdMiral OF THE SAME \&C. IN THE YEAR 1711." Jac. arm. Supporter's. (F., 8924.) 
AnMs.-Argent, a human heart proper crowned, on a chief Azure three mullets; impaling: Azure fretty Argent, a chief Or [ST. LEgen]. Supporters, A negro proper with feathers on his head, a cloth around the loins, and holding a bow in his dexter hand. A nude white man with cap on his head, his loins encircled with leaves, and a club in his sinister hand.

CREST.-An arm in armour embowed, holding a short sword.

Motto.-SApientia et riRtus.

In St. John's church-yard is a slab recording the death in 1713 of his infant son, "great grandson by Mother's side to Anthony St Leger of Ireland, who was twice Lord Leiut," and with the above arms thereon. Gorernor Douglas was superseded 1714-15, and in 1716 sentenced to five years imprisonment and a fine of $£ 500$.

41. "WiLt, Duer EsQR." Name in a festooned frame. Crest. (F., 9191; Allen, 235.)

Crest.-A dove with wings expanded, in its beak a sprig of laurel.

Motтo.-Esse fT viderI. See 108 for the arms of Duer impaled by Rose.

Youngest son of John Duer, born 1747, died in New York 1799.

42. "E Libris Gul. Alex. Duer." Plain arm. Motto as above. (Allen, 234.)

Son of the preceding, born 1780, Judge 1822, President of Columbia College 1829, died 1858. A second plate has "LL.D.," and a third one "Arm" added after Duer. (F.M.)

43. "WILL FraSER, M.D." Festoon arm. (F., 11,277.)

Arms.-Quarterly: 1 and 4, Azure, three cinquefoils; 2 and 3, Gules, three antique crowns.

Crest.-A stag's head erased [Fraser of Pitcallain]. Motto.-Je suis prest.

Perhaps of A., born there 1753, M.D. Edin. 1775, d. 1807.

44. "Nathaniel Bogle French." (F., 11,3S3.)

Anws.-Quarterly: 1 and 4, Or, a chevron between two roses in chief and a ship in base [BoGLE]; 2 and 3, Sable, a bend between two dolphins embowed Argent [FRENCH].

Crests.-1, A rose; 2, A fleur-de-7is issuing from a crescent.

Of Cedar Valley, later of Dulwich, born 1758, mar. 1792 Eliz. Skottowe, and died 1816. His father, James Bogle, mar. 1748 Eliz., dau. and heiress of Nath. French of A.

45. "Williaj Nathaxiel French mpcclxvi." Printed label. (F., 11,394.) Son of John French of Barbados (brother of Nath. French of A.), Lieut. in Deacons Musquetiers, mar. Mary Arabella Nicholas of A., and died 1799.

46. "Willian Forlong." Pict. arm. trophy. 1815 water-mark in paper. (F., 11,486.)

Perhaps of A.

47. "NATH ${ }^{\mathrm{L}}$ GILberT EsQ ${ }^{\mathrm{B}}$." Jac. arm. about 1740.

Arus.-Gules, a leg in armour couped at the thigh, between two broken spears in pale Or. CREsT.-An arm in armour grasping a spear. (F.M.)

Born 1697, M. of C. 1750, and died 1761.

48. "ArCH ${ }^{\mathrm{D}}$ Gloster." Chip. arm. These seem to be the al'ms of Devereux, Earl of Salisbury. (F., 12,029.)

Arms.-Paly vairé, Argent and Azure, on a chief Or a lion passant Sable.

Motio. - LeVius fit patientia. 
A surgeon, mar. 1759 Russell Hawes, and died 1773, leaving a son of the same names, bap. 1762, Attorney-General of Trinidad and Chief Justice of Dominica, mar. 1785 Eliz. Jarvis, and died 1825.

49. "JaMes Gordor, EsQ ${ }^{\mathrm{R}}$ Moor-Place." Arm. (F., 12,274. Illustrated in A., ii., 22.)

Anus.-Azure, three boar's' heads couped, on a fess chequy Argent and Azure a lion passant. CREsT. - A stag's head couped.

James Brebner, on succeeding in 1768 to the estates of his uncle James Gordon, Chief Justice of St. Kitts 1735-41, M. of C. of A., and of Moor Place, co. Herts, took the name of Gordon. He was M. of C. of A. 1761, Chief Justice of the Ceded Islands 1767 , and died in 1807, aged 83.

50. (Gunthorpe). ? Anonrmous. Arm. (Dr. Athrll-Crutrwell.)

Arus.-Gules, a bordure and bend gobonated, Argent and Azure, on the bend between two lions' heads erased of the second three leopards' faces Or.

CREST.-A lion's head erased and collared.

51. "Johr Demap Harlidat EsQR." Arm. spade shield. (F. 13,381.)

Aruss.-Quarterly: 1 and 4, Argent, a sword palezays, the pomel within $\alpha$ crescent in base, a chief Ermine, a canton Azure, charged with a cross of $S t$. Andrew of the 1st [HALIIDar of Annandale]; 2 and 3, Argent, an eagle displayed Sable [DetaP], impaling Quarterly, 1 and 4, Sable, a fret Argent [TOLLemache, but the tinctures reversed]; 2 and 3 , Azure, a crown between three mullets within a double tressure flory counter-flory [MURRAr].

Born 1749, mar. 1771 Lady Jane Tollemache, and died 1794.

52. "Francis Delap Haldiday." Festoon aim. (F., 13,379.)

Crest. $-A$ boar's head couped.

Arms.-Quarterly: 1 and 4 [HALLIDAY] 2 and 3 [DeLAP], a crescent for a difference. Motto.- - virtute PaRta.

Younger brother of John, born 1758, died 1794.

53. "Francrs E. Hallidar." Arm. (F., 13,380.)

Arms of Halliday quartering Delap.

Crest and Motto as above.

54. "Samuer Harmar." Arm. (F., 13,816. Illustrated in A., ii., 62.)

ARMs.-Quarterly : 1 and 4, Azure, a chevron between six rams accosted counter. trippant, 2, 2, and 2, Argent, attired Or [HARMAN]; 2 and 3, Per pale Or and Azure, a fess counterchanged [Cusack].

CRest.-A demi-man proper, crowned with an Eastern coronet Or, chained around the waist, and holding the end of the chain in the sinister hand of the last, the dexter hand holding a withered tree torn up by the roots proper.

MIotTo.-FIDELITER.

Son of Sam. Harman by Mary, dau. and heiress of Dr. Patrick Cusack. Born 1764, mar. 1786 Mar'y Ann Athill, and died 1816.

55. "War Hersham Esq ${ }^{\mathrm{R}}$ Greenwrch iN Kent." Early Jac. arm. (F., 14,660 , two states J.M. Illustrated in Howard's "Misc. Gen. et Her.," New Series, iv., 375.)

ARMs.-Argent, an anchor, on a chief Gules three bezants.

CREST.-On a mount vert a stag courant, its throat transfixed by an arrow, dropping blood.

Born 1691, M.P., mar. 1719 Sarah Perry of A., and died 1727. 
56. "JaMes M. HrLhouse (Burnell sc.)." Chip. arm. (F., 14,727.) Engraved about 1840 (Fincham).

Anus.-Argent, a chevron between in chief two mullets, and in base a human heart, all Gules, penetrated by six arrows, a crescent for a difference.

CREsT.-An arm in armour embowed, holding a dart bendwise.

James Martin Hilhouse. This family was of Bristol and A. Emma, wife of Martin Hilhouse, died 1840. James Hilhouse of Bristol, merchant, will p. 1754 (15, Pinfold).

57. "Geo. Fahie Horsford" by $W$. Gingell of Bath (Fiucham).

58. "Robert Marsh Horsford. Gingell fc. Bath." Arm. with mantling. (F., 15,393.) Engraved about 1820 (Fincham).

ARMs.- Azure, on a chevron ermine three eagles' heads erased Sable, between three swords erect, a martlet charged with a label for a difference (as first son of the fourth house Horsford), impaling: Quarterly, 1 and 4, Argent, two battle-axes in saltire Sable [MADDISON]; 2 and 3, Argent, on a chevron Sable, between three martlets of the second, a mullet pierced Or [MARLEY].

CREST.-O Over an esquire's helmet: Issnant from a mural coronet gules a demipegasus with wings addorsed Ermine, gorged with a collar gemel, also Gules, and holding between the paws a titting-spear erect. Motro.--JUSTITIA ET Clementia. (Illustrated in A., iii., 429.)

Born 1798, K.C.B. 1841, Chief Justice of the Leeward Islands, etc., mar. 1, in 1826, Mary Furlong, and 2, in 1830, Eliz. Maria Maddison, and died $\mathbf{1 8 7 5 .}$

59. (Hutcheson). Anonymous. Early arm. The large plate occurs as a frontispiece to a collection of treatises relating to National Debts and Funds 1717-19, by Archibald Hutcheson of the Middle Temple, London, Esq., and M.P. for Hastings. London, 1721. It occurs in a copy presented by him to the Speaker, Artbur Onslow. (F., 15,832 and 15,833.)

ARys.-Gules, three arrows, points upvoard, Or, the middle one in pale, the other two in bend dexter and sinister; on a chief purpure a boar's head erased Or.

No Crest. MotTo.-Contra PATRI IN INIICOS.

He was a native of co. Antrim, Ireland, but apparently of Scotch descent, born 1661, Attorney-General of the Leeward Islands 168s, M.P. Hastings 17131727, Commissioner of Trade and Plantations, friend of the Duke of Ormond; mar. 1, Mary Smith, who died 1698; 2, Rebecca; and 3, Eliz., and died 1740 . Will (227, Browne). Attached to a paper of 1692 is bis seal with the above arms. (B.T., Leeward Islands, vol. v., P.R.O.)

60. "Thomas Jarvis." Arm.

Anus. - Sable, on a chevron engrailed between three doves Argent as many mullets pierced of the first; on a chief of the second a fleur-de-lis between two escallops of the field.

CRRST.-A unicorn's head erased, gorged with a collar charged with three annulets. Mотто.-ALL FOR THE BEST. (Illustrated in A., ii., 98.)

Of Mount Jarvis, died 1877, aged 42. Tomb on his estate.

61. "George Ratph Payxe Jarvis." Arm. (F., 16.328.)

Arms of Jarvis (but with cinquefoils instead of mullets) impaling: 1, Paly of six Argent and Azure, on a chief Gules a lion passant guardant Or, all within a bordure Ermine [BLackweLL]; 2, Azure, a chevron between three crosses-crosslet fitchée Or, within a bordure engrailed of the last [STCRGES].

Crest as before, but collar charged with cinquefoils. (Illustrated in A., iii., 432.)

Born 1774, mar. 1, in 1802, Philadelphia Blackwell; 2, in 1830, Frances Sturges, and died 1851 . 
62. "C. M. G. Jarvis." Pict. arm. (F., 16,325.)

Crest and single coat of Jarvis.

Rev. Chas. Macquarie Geo. Jarvis, second son of the above G. R. P. Jarvis.

63. "E. G. JARVIS." Crest. (F., 16,326.)

Edwin Geo. Jarvis, fifth son of the above G. R. P. Jarvis.

64. "Godschall Johnson." Festoon arm. (F., 16,533.)

Arms.-Quarterly: 1 and 4, Argent, a saltire Sable, on a chief Gules two wool-packs Argent [JоHnson]; 2, Gules, a bend engrailed Or between six cinquefoils [WARNER]; 3, Gules, three catherine wheels within a border engrailed Argent [Scotr of Barbados]. CRest.-A castle.

Of Putney Hill, son of John Johnson by Eliz. Anne, second dau. and coheiress of Col. Edw. Warner of A. Born later than 1740, mar. 1, Eliz. Hodges, and 2, in 1792, Mary Francis, and died 1800. His plantations in A. were inherited by bis eldest son and heir of the same names.

65. "Robert Godschatl JoHnson." Festoon, arms quarterly, branches from upper angles of shield. (E.L.J., xv., 155.)

66. "LAdy Davy." Arm. lozenge. (F., 8164.)

Arurs.-Sable, a chevron engrailed Erminois between two annulets in chief, and in base a flame encompassed by a chain. Also the badge of Ulster (DAvY); on an inescutcheon, Gules, on a cheoron three mullets between a fleur-de-lis in chief, and in base a dove [KERR]. Granted to Kerr of Northampton in 1787 (Burke's "Armory").

Jane, dau. and coheiress of Chas. Kerr of A., mar. 1, in 1799, Dr. Shukbrugh Ashby Apreece; 2, in 1812, Sir Humphry Davy, created a Baronet 1818, and died 1855 .

67. "KERR." Arm. wreath.

Arurs.-Gules, on a chevron three mullets Argent between a fleur-de-lis in chief and a dove in base [KERR of Northampton, granted 1787]; impaling: Or, on a fess dancettée Azure three estoiles, on a canton of the second the sun in splendour [THONPson].

CRest.-A stag's head erased. Motto.-DeUs solamen.

Another similur plate has no name. (F.C.)

68. "Matthew Krrwan." Arm. spade shield. (F., 17,265.)

ARMs.-Argent, a chevron between three choughs proper.

Crest. $-A$ chough. Motro.-Fidelis ad Mortem.

Younger son of John Kirwan of Lime Street, W.I. merchant, and of A., who died 1799. He was of London in 1816.

69. (LaygFond-Brooke). Axonymous, Arm.

ARMS.-Quarterly: 1 and 4, Or, a cross engrailed per pale Sable and Gules (rightly Gules and Sable) [BRооке]; 2 and 3, Azure (rightly Gules), a shoveller close Argent [LANGFORD]; impaling: Argent, two bars Gules, on a canton of the second a cross of the field [BROUGHTON].

CRest.- $A$ badger. Motro.-vis UntTa Fortion.

Thomas Langford-Brooke of Mere Hall, Cheshire, mar. 1790 Maria Broughton, and died 1815, aged 46 . I found the above plate among the papers of my great grandmother, a sister of Thomas Langford-Brooke, but it may not have been strictly a bookplate.

70. "Liliar Langford-Brooke. Mere. Vis unita fortior."

House and garden as a vignette surrounded by a border of arum lilies. Modern plate. (Illustrated in E.L.J., xiii., 125.) 


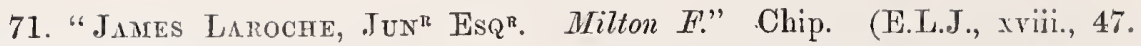
Not in Fincham.)

James Laroche, Sen., an alderman and merchant of Bristol, died 1770. His nephew the above, born 1734, mar. 1764 Eliz. Rachel Anne, dau. and heiress of John Yeamans of A., was created a Baronet 1776, and died s.p. about 1805.

72. "JACOB Leroux Esquire." Festoon arm. printed in sepia. (F., 18,164.) Plate about $1770-80$. (F.C.)

Aruss.-Azure, a chevron Argent between three leopards' faces cabossed Or.

Crest.-A lamb, supporting with its left leg a spear and pennon.

MotTo.-FORTITUDINE SED LENITATE.

Jacob Leroux of A. mar. 1707 Sarah Child, and the above may have been a descendant. Buried at St. Paul's, Covent Garden. "1799, May 2, Jacob Leroux, Esq. From St Pancras. Aged 61 years."

73. "Willian Lindsex, Antigua." Arm. spade shield. (F., 18,353.)

Arus.-Gules, a fess checky Argent and Azure between three stars of the second.

Crest.-A withered branch of oak. Motto.-Montud vivescunt.

W. Lindsey of A. died 1743, and his grandson Rev. W. Lindsey, bap. 1753, died 1812.

74. "Tobras Liste." Jac. arm. (F., 18,370.)

Arurs.-Emine, a lion rampant Gules.

Crest.-A swan's head erased. Motto.-Justita omnibus.

A Commander R.N., mar. Eliz. Pearne of A., and died 1719.

75. "Fermer Liste." Early Jac. arm., ? a bookplate. (F., 18,368.)

Arms (the lion Azure) and Crest as above.

Elder brother of Capt. Wm. Lisle of A., and nephew of Tobias, was of Evenley, co. Bucks, and died a bachelor 1742, aged 43 .

76. "Collex Lrons, of River Lyons EsQ." Early Jac. arm. (F., 18,985.) Arus.-Quarterly: 1 and 4, Argent, a chevron between three lions sejant Sable; 2 and 3, Or, a lion rampant Sable, sollared and roped [COLLEY].

Crest. - A lion's head erased Sable over a cap of maintenance.

MOTTO.-NOLI IRRITARE LEONES.

Geoffrey Lyons of River Lyons, King's Co., eldest brother of Henry Lyons of A., mar. Jane, dau. of John Moore by Ellen, dau. of Dudley Colley, and died before 1714, leaving an only son, Colley Lyons, M.P., LL.D., who died about 1741 .

77. "The Honble Josrah Mar'tin of Axtrgua EsQR." Jac. arm.

ARurs.-Gules, a chevron between three crescents Argent.

Crest.-A dexter hand grasping a falchion.

Motro.-PUGNa pro patria LiberTA. (Allen, 557. Illustrated by F.C. in E.L.J., xviii., s4.)

Born 1699, M. of C. of A. 1735-9, President 1746-50, M. of C. of New York 1759-62, mar. 1, before 1726, Mrs. Chester; 2, in 1735, Mary Yeamans, and died at Rockaway, Long Island, 1778.

78. "Samele Martin." Chip. arm. (W.E.B.)

Col. S. Martin of A., elder brother of Josiah, died 1776, aged 83. His eldest son Sam., born 1714, M.P., died 1788 bachelor. (Ante, II., 298.) The plate may have been used by either. In the Ponsonby Collection Mr. F. C. and I saw this plate of the single coat of Martin with SAMUEx stopped out and WiLliam written in ink.

79. (Martin). Anonymous. Chip. arm.

Single coat and crest (a cubit arm instead of an arm in armour) of Martin. 
Motto above: pRo PATRIA, and written signature of "Josiah Martin," the last plate with name of Samuel Martin cut off. (Illustrated in E.L.J., xviii., 84, by F.C.)

Nephew and son-in-law of the preceding, Lieut.-Colonel 6Sth Regt., M. of C. of A. 1766, Governor of N. Carolina 1770-5, and died in London 1786.

80. (Martin). Axonrmous. Festoon arm.

ArMs.-Martin, with martlet for cadency; impaling: Argent, a saltire Azure [YORKE].

William Byam Martin of White Knights, Reading, born 1744, Sheriff of Berks 1787, mar. Charlotte, dau. of Col. Yorke, R.A., and died 1S06. (Illustrated in E.L.J., xviii., 85, 125 , by F.C.)

81. "WILL MaRTiN." Chip. arm.

Crest and siugle arms of Martin. Motto over crest.-PRo Patria. (F.M.)

Wm. Thos. Martin, M.D. Cam., third son of Sam. Martin of Green Castle, A., died about 1735, leaving an only son, the above Wm., born 1733 in London, mar. 1762 Eliz. Galpine, emigrated to Boston 1783, and died 1814. (A., iii., 440.)

82. "Thomas Bram Martix." Arm. (F., 19,873.)

Arms of Martin; anchor at centre of chevron, a mullet for difference.

Another plate with Supporters. (F., 19,874.)

Two anchors on the chevron. Supporters: An eagle gorged with a coronet and a sea how'se gorged with a coronet. Two mottoes.

Younger brother of the 2nd Bart., born 1773, K.C.B. 1815, G.C.B. 1830, Admiral of the Fleet 1849, mar. Cath. Fanshawe, and died 1854. (D.N.B.)

83. "Josiah Martin." Plain arm. shield.

Single coat of Martin, with the addition of an anchor at centre point of chevron, and a crescent as second son of Sir Henry Martin, the 1st Bart.

MotTons.-Above, pRo patria; below, aUXILIO AB aITO. (Illustrated in E.L.T., xviii., 83, by F.C.)

Born 1772, collector of customs at A., and died 1849.

84. "Sir Henry W. Martin Bart." Wreath and ribbon arm. (F., 19,851.) Arus.-Gules, on a chevron Argent an anchor between three crescents. Badge of Ulster.

Cres's.-A hand, couped, holding a falchion.

Mottos.-Above, pro patria; below, auxilio aв aLto.

Born 1768, succeeded as 2nd Bart. 1794, and died 1842.

85. "Henry Bram Martin." Crest in a garter. (F., 19,850.)

Crest of Martin. MotTo.-PRo Patria.

Admiral and K.C.B., younger brother of Sir Wm. Fanshawe Martin, 4th Bart., and died 1865 .

86. "TVilliam Fanshawe Martin." Arm. (F., 19,879.)

ARus.-Gules, on a chevron Argent two anchors between three crescents. Badge of Ulster iu centre, impaling Quarterly : 1, Sable, a fess between 35 -foils Or [Hunt] ; 2, Gules, a wolf passant [Lowe]; 3, Azure, a stag trippant [Lowe]; 4, Argent, a bugle horn between three crescents, each charged with a pellet [FAwNE]. Crest and two Mottoes of Martin.

Born 1801, K.C.B. 1861, Admiral 1863, succeeded 1863 as th Bart., G.C.B. 1873, mar. 1, in 1826, Anne Best; 2, in 1838, Sophia Fliz. Hurt, and died 1895. (D.N.B.)

87. (Martin). Name cut off. (F., 19,883.)

Arms of Martin, but without the anchor. Crest. Motro.-pro patria. 
88. "John Pollexfen Bastard." Arm. (F., 1736.)

ARMs.-Quarterly: 1 and 4, Or, a chevron Azure [BASTARD]; 2 and 3, Quarterly, Argent and Azure, in the first and fourth quarters a lion rampant Gules [PotheXFer].

CIREST.-A dexter cubit arm embowed in armour, couped, holding a sword fessways.

89. (Bastard). Anonyarous. Arm. lozenge.

Aras.-Bastard quartering Poldexfes, impaling: Gules, on a chevron between three crescents an anchor erect cabled [MARTIN].

John Pollexfen Bastard of Kitley, born 1756, M.P. Devon, mar. 1809, as second wife, Judith Anne, third dau. of Sir Henry Martin, 1st Bart., and died 1816. She died 1848. (F.C.)

90. "MaXWELl of CARriden." Arm. spade shield in a frame. (F., 20,080.)

ARMs.-Argent, a double-headed eagle displayed, on the breast an escutcheon with Argent, a saltive Sable charged with a hedgehog, within a bordure Gules.

Crest.-An eagle with wings expanded. Motro.--Reviresco.

Wm. Maxwell, Sen., was of A. and Carriden, co. Linlithgow, and died about 1768.

91. "Valentine Morris." Arm. Noted in pencil "abt. 1760," but it is lithographic so must be later than 1798. (F., 21,160. Illustrated ante, I., 49.)

ARMs. - Sable, a lion rampant between three scaling ladders Or [MonIIs]; impaling, Or, on a chevron three horseshoes of the first, on a chief Gules three fleurs-de-lis of the second [W ATKINs].

CREST.-A demi-lion couped rampant Or.

Motto.-DECit amor PATris. This may not have belonged to Valentine Morris of Antigua.

92. "VAI MoRris." Chip. arm. (F., 21,159.)

AnMs.-Quarterly: 1 and 5, Gules, a lion rampant reguardant; 2 and 6, Argent, 3 boars' head's couped Sable (these two coats are those of Morris of Yorkshire, represented by Capt. Henry Gage Morris, R.N., as given in Burke's "Armory") ; 3 and 4, Sable, on a fess Argent between three eagles' heads couped, as many escallops [Wіцгот]; 7, On an escutcheon of pretence: Argcnt, a chevron between three estoiles [MoRDAUNT].

Born 1727, mar. 1748 Mary, eldest dau. and coheiress of the Hon. and Rev. Geo. Mordaunt. Val Morris's mother was Eliz. Wilmot. He was Gov. of St. Vincent 1776-9, and died 1789. In the preceding plate the coat of Morris is quite different.

93. "Walter Nugent." Festoon arm. (F., 22,096.)

AnMs.-Ermine, two bars Gules.

Crest.-A cockatrice. Motro.-Decrevi. Perhaps of A.

94. " $\mathrm{S}^{\mathrm{R}}$ Johr Ogitur of Innercarity $\mathrm{R}_{\mathbf{A R}} \mathrm{R}^{\mathrm{T}}$." Chip. arm. supporters. (F., 22,218.)

Anus.--Quarterly: 1 and 4, A lion passant reguardant, crowned, gorged with a crown, in its dexter paw a sword; 2 and 3, Argent, an eagle displayed Sable [RAMSAY]. On an ineseutcheon the Badge of Nova Scotia.

Crest. $-A$ demi-lion rampant, couped. Supporters: Two savages wreathed around the head and loins with leaves, and holding branches in their outer hands.

MotToes.-Above, Forward; below, TERRENA PERICULA SPERNo.

Two states (J.M.), of which the earlier has John Ogilvy, Esqra of Innercarity (F.C.) $(22,218$.)

Succeeded 1743 as 5 th Bart., mar. 1754 Charlotte, dau. and heiress of Dr. Walter Tullideph, was M. of C. of A. 1782, and died 1802.

95. "Richard Otiver A.M." Engraved label. 
96. "Richard Otiver A.M." Spade shield arm. (Illustrated in A., iii., 444.) ARMs.-Ermine, on a chief Sable three lions rampant Argent.

Crest.-A lion's head erased, collared Argent.

Eldest son and heir of 'Tho. Oliver of A., Leyton, co. Essex, and Mark Lane, born 1761, Fellow Cominoner of Clare Coll., Cam., B.A. 1784, M.A. 1788. Owned estates in A. and Grenada ; died 1821.

97. "Thomas OLITer Huntly 74 New Bond Street." Crest. Noted in pencil "1816." (F., 22,304.) Omitted by Fincham. On the back of the copper plate is stamped in the metal, WILL ${ }^{\mathrm{Br}}$ \& $\mathrm{RUSS}^{\mathrm{L}}$ PONTIFEX \& COMP ${ }^{\mathrm{x}}, \mathrm{N}^{\mathrm{OS}} 46,47 \& 48 \mathrm{sHOE}$ LANE, LONDON.

Tounger bro. of Richard; of 10 Deronshire Place, born 1764, died 1842.

98. "OLiver." Crest. Large size.

Crest.-A lion's head, couped, collared, and ringed. Thomas Wm. Oliver, Commander R.N., of Oak Hill, Bursledon, co. Hants, eldest son of Tho. Oliver, Jumr., of 10 Devonshire Place and Child Okeford, co. Dorset, born 1S32, died 1901.

99. "Oriver." Pict. from a drawing of H.M. Brig "Kingfisher," used by the preceding.

100. "Charles L. Oliver." Crest as in 96.

Second son of Tho. Oliver, Junr., Lieut. Fifth Fusiliers, born 1835, died 1908. to 100 .

101. "Wrlltam Henzey (orrer" of the Bengal Engineers. Similar plate

Third son of Tho. Oliver, Jun., born 1837, died 1859.

102. "Vere L. Outrer." Crest of Oliver.

103. "Vere Lanaford Oliver" (Asprey, New Bond Street, about 1885). Chip. arm.

Arus.-Quarterly : 1 and 4. [OLIvER]; 2 and 3, Gules, a shoveller close Argent [Lanaford of A.] ; impaling Martin, quartering Holloway. (Illustrated in A., ii., 319.)

104. "James Ados. Odahton." Jac. arm. (F., 22,473.) Single coat of Oughton.

105. "Lievt-Genl. Ovahton." Arm. trophy. Arms, Oughton impaling

Ross. (F., 22,474. Illustrated in E.L.J., vii., 160.)

ARus.-Per pale Gules and Azure, over all a lion rampant [Oughton], impaling: Gules, three mullets in fess between three lions rampant [Ross].

CREST. - A tower with the sinister comer of the battlement broken away and thereout hanging a branch. MOTTO.-NESCIT ABOLERE VETUSTAS.

Sir James Adolphus Dickenson Oughton, nat. son of Sir Adolphus Oughton of Tachbrook, Bart., born 1720, Lieut.-Genl. 1770, K.B., Lieut.-Gov. of A.1772, mar. Mary, sister of Capt. John Ross, and died at Bath 1780. (D.N.B.)

106. "Sir Adolphus Otgrton." Arms encircled with the motto of the Order of the Bath and supporters. (F., 22,475. Illustrated in E.L.J., vii., 158.) Supporters: two lions rampant, guttée de sang, collared Ermines.

107. "Geo. Rose, EsQR." Chip. arm. (F., 25,497.

A RMs.-Or, a boar's head couped between three zuater-bougets Argent; impaling: Ermine, a bend Azure [DUER].

Crest.-A harp. Motro.-Constant and tRoe.

Born 1744, P. C. Treasurer of Nary, Clerk of Parliaments, mar. 1769 Theodora Duer of A., and died 1818.

108. "The Right Hovorable Georé Rose." Arm. (F., 25,498.) Rose impaling Duer. Crest. No Motto. 
109. "The Right Honorable George Rose, Old Palace Yard." Arm. (F., 25,499.) Arms, Rose impaling Duer. Crest and Motto.

Different design from 25,498.

110. "The Right Honorable George Rose." Arm.

Crest, Arms of Rose impaling Duer, and Motto. Above the Crest is a baron's coronet with the letter " $\mathrm{Ml}$ " below it. (F.C.) Not in " F."

111. "Isaac Rotall Esq ${ }^{\mathbb{B}}$ of Axtigua." Jac. arm. (F., 25,640; Allen, 743.)

ArMs.-Azure, three garbs banded.

Crest.-A demi-lion rampant, holding in its fore-paws a garb. (Illustrated in E.L.J., i., 45, and Curio 15.) Mотto.-pectore pUro.

Born 1672, of Boston, Mass., and A., died 1739. His son of same names bap. 1715, M. of C. of Mass. 1751-74, mar. 1738 Eliz. M'Intosh, and died 1781 in London.

112. "John Rutherford Antigua." Chip. arm. (F. 25,798.)

ArMs.-Argent, an orle Gules, in chief three martlets Sable.

Crest. - $A$ martlet Sable. Motto. - NeC sonte neC Fato.

A Dr. T. Rutherford was licensed at A. 1738, but nothing more seems to be known about him.

113. "John Rutherford M.D." Festoon arm. (F., 25,799.)

ARMs.-Argent, an escutcheon, in chief three choughs. No tinctures. Motto as above. F. 25.800 is the last plate reworked. Verv rough in execution, possibly engraved in the W.I. The escutcheon is now Gules, and charged with three increscents.

Boru 1695, of Edinburgh, died 1779. (D.N.B.) But rather early for a "festoon." (F.C.)

114. "Wr Salmond, EsqR Carlisle." Chip. arm. (F., 25,996.)

Arus. - Azure, three salmons in pale erect.

CREst.-A bare arm embowed, couped, holding a salmon-spear.

Born 1737, A gent for A. 1776, mar. 1, in 1759 , Eliz. Chalmers, 2, in 1765, Jane

Hasell of co. Cumberland, and died 1779.

115. "Јонм ScotLand." Arm. (F., 26,256.)

A RMs.-Argent, a chevron Azure between three lions' heads erased.

Crest.-A thistle. Motro.-Cave.

Perhaps a merchant of A. of Scotch descent, who died 1793, aged 63.

116. "James Bogle Surth." Arm. Arms, Smith impaling Massey (?) (F., 27,280.)

Arms.- Enmine, three torteaux, impaling five quarterings.

Crest. - Out of a coronet a plume of five ostrich feathers.

HotTo. - suUN CUIQUE.

Son of John Smith, a W.I. merchant, by Rebecca Bogle-French of A., born 1788, mar. 1, before 1829, Mary Ann Shawe, and 2, before 1859, Mary Stewart, and died about 1875 .

117. "ReV Rowland Smitu." Crest. (F., 27,370.)

Crest and Motto as above.

Brother of James, bom 1S07, Rector of Swyncombe, co. Oxou, living 1889.

118. "Adrian Joну SwEte." Chip. arm. (F., 28,616.)

AnMs.-Gules, two chevrons between two mullets in chief and a rose in base, seeded Or.

CREST.-A mullet Or, pierced Azure, between two gillyflowers proper. (Illustrated in A., iii., 452.)

Only child of Main Swete of A. and Modbury, co. Devon, born 1731, M.A.

Oxon 1751, d. bach. 1756 . Nos. 28,647 and 8 belong to his descendants.

119. "Sydserf of Ruchlaw." Jac. arm. (F., 28,700.) "

Aris.-Argent, three fleurs-de-lis Azure. 
Crest.-An eagle's head couped. Motto above.-virtute pronoveo.

Dr. Walter Sydserf of A., son of John Sydserf of Dunbar and grandson of Alex. Sydserf of Ruchlaw, co. Haddington, was born 1692 and died 1760.

120. "John StDderff of Ruchlaw." Arm. (18)24 water-mark in paper. (F., 2S,701.)

Arms and Crest as above, eagle erased and "MI" below.

121. ("Triomas.") "This Book belongs to Sir G. Thomas's Library, Dale Park, Sussex." Printed label. (F., 29,210.)

The 3rd Bart., M.P. for Arundel, died 1515.

122. "Margaret Thomas." Chip. arm. lozenge. (F., 29,227.)

ARus.-Argent, three lions rampant, a chief Azure.

Youngest dau. of Gov. Sir Geo. Thomas, lst Bart., mar. 1765 Arthur Freeman, and died 1797 , aged 51.

123. "Alexander Adair." Alm. spade shield. (F., 100.)

Anirs.-Per bend Argent and Or three dexter hands couped Gules, impaling: Argent, three lions rampant, a chief Azure.

Crest.-A man's head bearded, affrontée erased. MLtro.-LOYAI AU MORT.

Of Flixton Hall, co. Suffolk, mar. 1783 Lydia, dau. of Sir Wm. Thomas, 2nd Bart.

124. "Chartes Clement Tudway." Arm. (F., 29,930.)

Crest.-A demi-lion rampant, couped Gules, in dexter paw a rose slipped.

Anss.-Quarterly : 1 and 4, Ermine, a lion rampant Gules between three roses Azure; 2 and 3 , Vert, a chevron between three bucks trippant Ermine, impaling: Nelson. Motro.-NIL DESPERANDUMr.

Of Wells, co. Somerset, born 1846 and mar. 1, in 1870, Lady Edith Nelson, who died 1877.

125. "Datid Tulutdeph. F. Gardner Sculp." Jac. pict. arm. (F., 29,947.) Engraved about 1730. (Fincham.)

Arms.-Argent, a stag couchant between in chief two mullets of six points, and in base a crescent.

Crest.-A stag's head erased Argent. Motto.- Non ominus dormo.

Of Wisbeach, formerly of A., merchant, born 1705, died 1772. See notice of his brother, Dr. Walter T., No. 94. Another brother, Thos., Principal of St. Andrews, died 1777.

126. "H. Walrond." Arm. (F., 30,762.) Above is an earl's coronet.

ARMs.-Argent, three bulls' heads cabossed, impaling: Ermine, a lion rampant Azure, on a chief Sable a leopard's face between two crosses-crosslet fitchée [CLARK].

Supporters. - Two heraldic tigers rampant pelleté gorged with a ducal coronet and chained. Motto.-BIENFaIETz PAYERAY MAFaIETz vangeray.

Henry IV. of Dulford, co. Devon, born 1841, mar. 1861 Caroline Maud Clark. His ancestors were first of Barbados, later of $\mathrm{A}$. His father claimed the Barony of Welles.

127. "WM WARyer Esq ${ }^{\mathrm{R}}$ Axtigua." Chip. Crest. (F., 30,919.)

CREST. - A man's head couped at shoulders affrontée, a fillet around forehead, a fleur-de-lis on his chest.

Born 1728, M. of C., mar. 1754 Eliz. Blizard, and died 1771.

128. "EDWard Warner." Arm. (F., 30,912.)

ARMs.-Argent, a bend engrailed between six roses Gules, impaling: Quarterly, 1 and 4, Gules lozengy Argent within a bordure of the last [SHIPLEY ?]; 2 and 3 , Azure fretty Argent, on a canton a rose. 
Crest.-A man's head affrontée conped. Motto.-DC ror Je LE tiens.

Colonel in the Army, of Trinidad, mar. Cath. Jane Mathew, 1st dau. and coheiress of Major-General Sir Cha. Shipley, R.E., Governor of Grenada, and died 1849 , aged 74 .

129. "Francrs Fadquier, Esq." Chip. arm. (F., 10,257.)

Crest and Arms of Fauquier.

Born 1704, F.R.S. 1753, Lieut.-Governor of Virginia 175s, died at Williamsburg 1768, mar. Cath., eldest daughter of Sir Cha. Dalston, Bart., who died 1781, and had issue 1, Francis; 2, Wm., jun. Francis, selı., and his brother Wm., sen., were probably sons of John Fra. Fauquier, Director of the Bank of England, who died Sept. 1726.

130. "Ww FAUQUTER JUN"." Late Chip. arm. with festoons. Arms of Fauquier. (IV.E.B.)

Younger son of the Lieut.-Governor of Virginia, mar. 1771 his cousin Mary, dau. of $17 \mathrm{~m}$. Fauquier, sen., and died 1505 .

131. "Thomas FACQUier." Late Chip. with wreath around shieid.

ARMs.-Or, a tree on a mound, a falcon close in sinister point of base and a human heast in dexter point, in chief two mullets [FAUQUIER]. Quartering, 1, Gules, a bend engrailed Or between six cinquefoils Argent [W ARNER]; 2, Gules, three catherine-wheels Argent [Scotr].

CREST. - A falcon close. (F.C.)

Wm. Fauquier, sen., F.R.S., mar. 1742 Grace, widow of Sam. Byam and dau. and coheiress of Colonel Edwd. Warner by Eliz. Scott, and died 1788, aged 80, leaving with other issue a dau. Mary, who mar. $1771 \mathrm{Wm}$. Fauquier, jun., and an only son and heir, the above Thomas, Usher to Queen Charlotte, who mar. 1779 Mrs. Charlotte Norris, and died 1825 at Hampton Court Palace in his 80th year.

132. "Wм Whitehead." A

AnMs.-Azure, a fess Or between three fleurs-de-lis.

Crest.-A lynx sejant. Motto.-virtute et LAbore.

Perhaps of A. 1758, and later of Ormsby, co. Cumberland, mar. 1763 Jane Furnall, and died 1791.

133. "Gulielint Willians ex Ixsula Axtigca. J. Ingram fecit a Paris." Pict. arm. (Allen, 936; F., 31,944. Illustrated in Griggs, 2nd Series, and A., iii., 231.) Engraved about 1770. (Fincham.)

Aruss.-Quarterly: 1, Or, a winged griffin segreant Gules [WILLIans]; 2, Gules, a man's head proper bearded affrontée; 3, Árgent, two wolves (or foxes) counter salient Gules; 4, Argent, a lion rampant Sable, langued Gules.

CREST. $-A$ winged griffin segreant.

Fourth son of Col. Tho. Williams of A., a minor 1738.

134. "Edward Wrulrams EsqR." Chip. arm. (F,, 31,865. Illustrated ante, I., 97.)

Bapt. 1710, eldest brother of $\mathrm{Wm}$., died 1784.

135. "Rowl Edw" Willidurs EsQR." Chip. arm. No. 31,865, with inscription altered. (F., 31,928.)

Of A. and Thames Ditton, co. Surrey, born 1748, died 1826.

136. "Bexedict Wrulrs." Chip. arm. (F., 31,976.)

Ansis.-Per fess Gules and Argent, three lions rampant counterchanged within a bordure Ermine.

CrEst.-Two lions' gambs couped, erect, holding an escutcheon Or.

Of London, merchant, mar. about 1750 Mary, only dau. and heiress of Robert Freeman of A., and died 1774-7. 
137. "Webs Wilits." Chip. arm. No. 31,976, with altered inscription. (F., 31,98T.)

Joseph Webb Willis, second son of the abore B. Willis, was of University College, Oxon, and Lincoln's Inn, and died a bachelor on his passage from A. 1775, aged 24.

138. "Cilarles Wr. Willock. W. Mathews, sc." Arm. (F., 31,992.) Engraved about 1830. (Fincham.)

Anus.-Argent, on a fess Gules three escallops between as many eagles' heads erased.

Crest.-Over an antique crown an eagle's head erased. Motto.-FEar not.

Perhaps Rer. Chas. Wm. Willock of Burton Hill, co. Sussex, born 1821, assumed the name of Dawes 1870. No. 31,996, anonymous, also has the above arms, \&c.

139. "Jons Young Esquire. A. Burden, scul." Early arm. (F., 32,917; E.L.J., vi., 57.) Engraved about 1700. (Fincham.)

Anus.- Argent, on three piles Sable three annulets Or.

Crest and IIotto of Toung.

140. "Johr Youxg EsQR." Jac. arm. (F., 32,918.)

141. "Willian Iouxa Esq." Jac. arm. (F., 32,939.)

Arurs-Or, issuing out of chief three piles, and in chief three annulets Sable.

Crest.-A dexter culit arm erect grasping a dart. MotTo.-PRess througir.

Boln 1657, surgeon, mar. 1720, and died about 1740, father of Wm., created Bart. 1769.

142. "Sir WM. Toung BAR" Clest. (F., 32,938.)

Crest of Toung, with badge of Ulster. On the arm is the name.

Motto of Young above, and in oval surround: MolTuM LEgenduM Esse NON MULTA.

143. "Sir Wм. Young, Bart.") Anonyarous. Pict, arm. W.I. palm trees, fruit, trophies, \&c. (F., 32,943.)

A RMs.-Or, issuing from the chief three piles, and in chief three annulets Sable.

CR EST.-A sinister forearm couped, erect, holding a dart bendwise.

Мотто.-PREss тпиобGп. From the large plate used for Jefferys' W.I. Atlas, dedicated 1775 to "Sir Wm. Young, Bart.. late Gov. of Dominica."

Born 1725, M. of C. of A. 1761, Lieut.-Governor of Dominica 1768-74, mar. 1, in 1746, Sarah Fagg, and 2, in 1747, Eliz. Taylor, and died in St. Vincent 1788.

144. "Sir Charles Lawrence Young Bart." Arm. (F., 32,903.)

Crest and Arms as in No. 32,917. Badge of Ulster. Motto. .

Born 1839, succeeded 1854 as 7th Bart., and died 1887.

\section{ADDITIONS.}

145. "W: Frre" Transitional Jac. arm. (F., 11,453.)

A RMs.- Vert, a fleur-de-lis between three horses courant Argent.

Crest.-A demi-horse evect couped.

Of Beddington, co. Surrey, died 1795, aged 80. The above coat is on the tomb of his father, the Hon. Col. John Frye, in the churchyard at Willoughby Bay, A.

146. "Thomas Ortver." Chip. arm. (F.C.)

Anss. - Ermine, on a chief Sable three lions rampant Argent.

CREst.-A lion's head erased collared.

Probably the plate of my great-great-grandfather, born 1740 at A., later of Layton, co. Essex, and 20 Mark Lane, mar. 1759 bis cousin Isabella, fifth dau. and coh. of Jonas Langford of A. and Theobalds, co. Herts, and died 1803 . Some of his silver bearing the arms of Oliver impaling Langford is still in use, but this bookplate is unknown to me.

Another Thos. O., first-cousin to the above, was born 1733-1 at A., Lieut.- 
Gov. of Mass. 1774-6, and then resided in Bristol till his death in 1815. He mar. 1stly in 1760 Eliz. Vassall, and 2ndly in 1781 Harriet, only child and heir of the How. Byam Freeman of A. Either man may have used the plate.

147. "Mich: Macnemara M.D." Chip. arm. (F., 19,404.)

ArMs.-No tinctures. A lion rampant, in chief two spear-heads.

Crestr.-A cubit arm, in the hand a sabre.

MotTo.-Firmitas in CELo. (F.C.)

Of London, physician, mar. (sett. dated 19 Jan. 1763) Mr's. Mary King, widow of Benj. King of Antigua, Esq., and dan. and heiress of Henry Douglas of the same I., Esq. At her death in 1778 they were of Great George Street, Westminster.

\section{CORRECTION (p. 3).}

No. 14. F. 4715 has the crest: A dragon's head erased, in its mouth a hand dropping blood.

The black impression of Francis Byam's plate is a difierent state from the sepia one. It has no blood dropping flom the hands. (F.C.)

\section{Ziabamas.}

148. "Thonas Atwood Esq. Chief Justice of the Bahama Islands." Festoon arm. (F., 949.)

Arms.-Argent, on a fess ragulé Azure three fleurs-de-lis.

Crest.-On a block of wood ragulé a fleur-de-lis between two sprigs.

MotTo.-TANDEM.

Chief Justice of Dominica, died 1793 in the King's Bench Prison.

149. "Thomas Atwood" Festoon arm. (F., 948.)

A different design. The same arms, with a crescent for a difference.

Crest.-A tree trunk, etc. Motto as before.

150. "William Brisbane." Ribbon and wreath arm.

Motto.-DABit ótia Deus. (Allen, 107; W.E.B.)

Eldest son of James Brisbane of Charleston, S. Carolina, who was banished as a Loyalist in 1782 , and died 1794 in the B., whence Wm. returned and died in Charlestou. (Ante, II., 190.)

151. "Chas. Camerov." Chip. arm. (F., 4934.)

Anus.-Argent, three bars Gules within a bordure Azure.

CREsT.- $A$ dexter hand erect couped, grasping a short sword.

MotTo.-PRo rege ét patria.

152. "Charles Cameron" Festoon arm. (F., 4935.)

ARMs.-Gules, three bars $0 \eta$. Motto as before.

Crest. - A dexter arm in armour embowed, couped, grasping a sword.

Governor of the B., died at Roydon, co. Norfolk, 1828. By his wife Lady

Margaret Hay he had a son Cha. Hay C., of whom there is a notice in the "D.N.B."

153. "Henry Moreton Dren" Arm. spade shield. (F., 9429.)

Arus.-Quarterly: I. and IV., Or, a chief Sable [DYER]; II. and III., quarterly,

1 and 4, Argent, a chevron Gules between three square buckles [MonetoN];

2 and 3, Or, two lions passant [DUCIE].

CrĘst. $-A$ goat's head out of a coronet.

MotTo.-Nec Ullo CASU Ulia intermissio OFFicit.

1810, Dec. 25. At her grandson's, at Nassau, New Providence, in her 91st year, the Hon. Anne Louisa Moreton, widow of the late Hon. Major Charles Moreton the youngest son of the first Lord Ducie, \& maternal grandmother of Henry Moreton Dyer, esq. Judge of the Vice-Admiralty Court of the Bahama Islands. ("G.M." for 1811, 395.) 
154. "Murrit, Earr of Dexmore." Arm. supporters. (Allen, 602.) From Tirginia to Nassau. (F.M.)

John, 4th Earl, Governor of Virginia during the revolutionary war, was appointed Governol of B. in 1786, and died in England 1809, aged 77. (F.C.)

155. "Nassau Library, 1836." Large printed label. (IV.E.B.)

156. "Anthont Stokes of the Inner Tenple, Esqr 1760" Chip. arm. (F., 28,251.)

Arus.-Sable, a lion rampant Ermine.

Crest. - A falcon with wings expanded, in its beak a sprig.

On 15 May 1767 he was recommended to be of the Council of Antigna. In a list of the Council 15 Nov. 1770 he is styled Chief Justice of Georgia. In 1783 he wrote " "View of the Constitution of the British Colonies in N. America and the W.I." In 1792 he was Agent for the B. (F.C.) Sabine merely names him.

157. "E. R. WEGG" Chip.

Edmund Rush Wegg, Attorney-General of Florida, later of the Bah. 1785. (F.C.) Not in Sabine.

158. "Wrltian WrLty Georgia" Printed label.

159. "Wrltiam TVrely EsQ" Festoon arm. A Royalist refugee. (F.M.) Chief Justice of B. in 1798. (F.C.) Attorney-General 1807.

\section{Biarbaios.}

160. "Thomas Maxwell Adams" Arm. spade shield. (F., 158.)

ArMs.-Argent, on a cross Gules five estoiles.

CREST.-Out of a coronet a demi-lion affrontée.

Son of Thos. A. of B., matric. from Merton Coll., Oxf., 1764, aged 19. (Foster.)

161. "William Adamson." Arm. (1., 171.)

ARMs.--Argent, three crosses-crosslet Gules, in centre base point a mullet Azure. CREST. - A sword and cross-crosslet fitchée in saltire.

MotTo.-CRUX MIHI GRATA QUIES.

Perhaps of St. John's, B., in 1820. (Foster.)

162. "Sir Rernold Abel Alueyne BaR Johnson sc" About 1840. Not in Fincham.

AnMs.-Quarterly : 1 and 4, per chevron Gules and Ermine, in chief turo lions' heads erased $\mathrm{Or}^{\prime} ; 2$ and 3 , Argent, two chevrons between three trefoils [SPIRE of B.], impaling, Gules, a lion rampant, collared Argent [OLToN].

МоTTO.-NON TUA SED PUBLICA VOTA. (F.M. and F.C.)

Born 1789, succeeded as 2nd Bart. 1801, mar. 1810 Rebecca Olton, and died 1870.

163. "Thomas Allerne $N$. H. Sculp." Chip. within a simple border. (Illustrated in E.L.J., xv., 134.) He mar. Miss Foster of B. (F.C.)

ArMs.-Single coat of A.

164. "JoHN ARCHER" Chip. arm.

ARMrs.-Azure, three arrows Argent pointing downwards.

CREsT.-Out of a mural coronet a wyvern's head. 
Motto.-Aim wel. (F.C.)

Perhaps of B., and died 1786, aged 50. (Archer, 375.)

165. "The Dowhaer Lidi Arundell of Wardour." Arm. lozenge with supporters and baron's coronet. (F., 763.)

Arus. - Sable, six martlets [AnuNDELL]; impaling, Quarterly, 1 and 4, Argent, a lion rampant Vert, quartering Argent, a chevron between three boars' heads couped; 2 and 3, Argent, in ehief two holly leaves Tert, and in base a bugle stringed [BURNETT $]$.

Mary, dau. of Robert Burnett Jones of Ades, co. Sussex, Attorney-General of B., mar. 1806 as second wife James Everard, 9th Baron, and died 1853. He died 1817. motto.

166. "Wilmie. Assheton Esq of Barbadoes." Chip. arm., rely ornate, no

He began the practice of law in Penmsylvania, and was afterwards described. as of the parish of St. Michael's in B., gent. He was Provost Marshal of B. (Allen, 36.)

"Buackman." See under "Antigua."

167. "Bishop of Srenra Leore." Arm. Probably the plate of Edward Hyndman Beckles, consecrated Bishop 1860. (F., 2004.)

Arns. - In a landscape with a line of peaks in the background a lion couchant, on a chief Gules two trumpets in saltive; impaling, Azure, a dove, in its beak a sprig.

CREsT. $-A$ mitre.

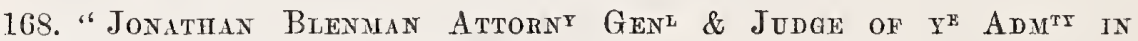
Barbados" Jac. arm. (Allen, 86.)

Arus.-Per chevron invected Azure and Argent, in chief two lozenges of the second, in base a bee; impaling, Argent, three daggers.

Crest.-A dexter arm couped, vested, in the hand a scroll.

Appointed Attorney-General 1727, and Judge of the Admiralty 1734.

169. "T. Blenuax." Arm. (F., 2825.)

A RMS.-Quarterly: 1 and 4, B., an annulet for a difference; 2 and 3, Gules, two lions passant Or [Dotrin]. Crest of B.

MotTo.-LABORA FRUEREQUE.

Wm. B. of Bath aud B. mar. 1748 Eliz. Dotin and had four sons (but the annulet denotes a fifth son). Rev. Timothy B. went to B. 1783 , and died at Clifton 1820.

170. "Pinson Bonham." Arm. Arms.-Bonham quartering Richardson, impaling Sketete.

ArMs.-Quarterly : 1 and 4, Gules, a chevron wavy between three crosses pattée fitehée Argent; 2 and 3, Argent, on a chief Sable three lions' heads erased; impaling, Or, a chevron between three fleurs-de-lis Gules.

CREST. - A mermaid proper.

MOTTO.-ESSE QUAM VIDERI.

General P. Bonham of Great Warley Place, co. Essex, born 1762, mar. Agnes, dau. of John Brathwaite Skeete, President of B. (F., 3033.)

171. "John Brathwaite EsQR" Chip. arm. (F., 3586.)

AnMs.-Argent, on a chevron Or three crosses-crosslet fitchée.

Crest.-A greyhound couchant, collared and chained. 
MotTo.-AEDACES FORTUNA JUVAT.

Perhaps the well-known Agent of B., born 1722, died 1800.

172. "Codrington Edup. Carrington." Arm. spade shield. (F., 5226.)

ArMs. - Sable, on a bend Argent three lozenges of the field, a label of three points for a difference. Mотто.-speno.

CREST.-Out of a coronet a unicorn's head.

173. "Sir Codrington, Edmond, Carrington F.A.S. F.R.S." Aim. (F., 5227.)

Arus.-Carringtox impaling Or, on a chevron Azure between in chief three Moors' heads proper, and in base a rose Gules, a mullet of eight points Or between two roses [BELLI].

CREST of C. over a knight's helmet.

Motroes.-Above: spero. Below: SURGE AGE.

There are other plates with the same arms of $\mathrm{C}$.

Born 1769, Chief Justice of Ceylon 1801, mar. 1stly in 1801 Paulina Belli, 2udly Mary Ann Capel, and died 1849. (Ante, I., 374, and "D.N.B.")

174. "Gedney Clarke Barbadoes" Festoon. (W.E.B.)

175. "Gedney Clarke Esq". Barbados." Chip. arm. (F., 5923.)

Arus.-Argent, on a bend Gules between three ogresses as many swans of the first ; impaling: Sable, a cross patonce Argent [L.iscelLes].

Crest. - A lark, in the beak an ear of wheat.

Motto.-esperez Le Minux. The earlier state of the plate has "Barbadoes." (F.C.)

G. C., Jun., mar. 1762 Frances, dau. of Edw. Lascelles, Collector of Customs at B. in 1775. G. C., Sen., probably his father, also Collector, died 1761.

176. "R. B. Clarke EsQR." Festoon arm. (F., 5951.)

Ariss.-Argent, three stags' heads cabossed. CReSt.-A bugle horn siringed.

Мотто.-LEx LiT JUstrita.

K.C.B. and Chief Justiee of B. 1850. F. 5966, "Thos. Clarke" has the same coat.

"Codrington." See under "Antigua."

177. "William Hart Coleridgr." Arm. (F.M.)

Boru 1789, only son of Luke Coleridge of Thorverton, Devon. Christ Ch., Oxon., matric. 1808, aged 18, B.A. 1811, D.D. 192t, Bishop of B. 1824-41, mal". 1825 Sarah Eliz. Remmell, and died 1849. ("D.N.B.")

178. "James Edward Colletor A.M." Jae. arm. (F.M.)

ARMs.--1st state: Argent, three bucks' heads couped; 2nd: Or, the "A.M." just visible; 3rd: Or, the "A.M." has disappeared. (F.C.)

Second son of John Colleton of B., was M.P. for Lostwithiel, mar. twice, and died s.p. 1787.

179. "Aвraham Cumberbatch." Arm. spade shield. (F., 7545.)

ArMs.-Gules, an eagle displayed between three trefoils.

Crest.-An eagle's head couped.

MotTo. -Ne TeNTes aUt PERFice.

There were three generations of these names. The first died 1753 , the second 17S5, and the third 1796. (Ante, II., 84.) 
180. "John Daniel. Anes sculp. Bristol" Festoon arm. (F., 7929.) No date assigned by Fincham.

Anus.-Paly of six Sable and Ermine, over all a lion rampant Argent.

CREST.-A dexter cubit arm erect, couped, gorged with a coronet, and grasping a dagger fessways.

181. "William Danieli, Bristoz. Lander sculp" Crest in a garter. (F., 7947.) Engraved about 1S20. (Fincham.)

Crest. - A lion rampant. Motro.-Firmum in vita Nihit.

They were also of B. (Cave's "History of Banling in Bristol," 228, and "TV.I. Committee Circular," vol. 27, p. 227.)

182. "Theophilus Desbrisax." Jac. al'm.

Subscriber to Hughes" "History of Barbados" in 1750. (F.M.) A Rev. T. Desbrisay, perhaps a son, was Governor's Chaplain at St. John's 1775. (F.C.)

183. "Henry Dottin Jun ${ }^{\mathrm{R}}$. of Clements Inne" Eurly arm. (F., 529.) Arus.-Or, two lions passant. Crest.-A hind statant collared.

Perhaps related to Dottin of B.

184. "Thomas ErLe Drax" Chip. arm. (F., 9057.)

Anus.-Checky Azure and Or, on a chief Argent a plume of ostrich feathers.

Of Charborough Park, co. Dorset, mar. Mary, dau. of Lord St. John, and died 1790 , aged 67. book.

155. "EDward Drax. R.M." Chip. arm. Taken from Mountaine's pattern

Anus.-Checky Argent and Sable, on a chief Argent a plume of ostrich feathers.

Of Charborough Park, co. Dorset, mar. 1762 Mary, dau. of Awnsham Churchill, and succeeded bis brother Tho. Erle Drax 1790. (F.C.)

1ธ6. "George Errixgton" Chip. arın. (G. Ponsonby Collection.)

Dep.-Registrar 1792. (F.C.)

187. "Hanlet Fairchild. Kivle fecit S S Paul's Churchyard." M. of Council. (W.E.B.) Chip. arm. (E.M:) Not in Fincham.

Anss.-Gules, a fess vair between two demi-cherubs couped in chief, and a parrot Argent in base. Cnest. - A deni-cherub winged Argent.

MotTo.-GaUdeT patientia duris. (F.C.)

The Hon. John Fairchild, Chief Justice for St. Michael's, died 1756.

188. (Frene.) Anonymous, or mutilated. Chip. arm. (F., 11,404.)

Anus.-Quarterly : 1 and 4, Gules, two leopards' faces cabossed between two Ranches Ermine; 2 and 3, Argent, a fess engrailed Azure between three pears [Applethilte]. CRest.-Out of a coronet an antelope's head.

Mot'To.-MENS CUJUSQUE IS ES'T QUISQUE.

John Frere, born 1706, Lieut.-Gen. and Gov. of B., mar. Susannah, dau. of Tho. Applewhaite, President of the Council, and died 1766.

189. "Sir Philip Gibies, Bar'T" Arm. (F., 11,805.)

Anurs.-Per fess Argent and Ermine three battle-axes Sable. On an inescutcheon: Quarterly, Azure and Erminois, a cross Argent [OsBonNe] with the badge of Ulster.

Crest.- $A$ dexter arm embowed, couped, charged with a cross Gules, in the hand a battle-axe Sable, bendwise.

Born 1730, mar. 1753 Agnes, dau. and heiress of Sam. Osborne, created Bart. 1774 , and died 1815 . 
190. "Gill, Whitehall Barbados." Crest? (IV.E.B.)

Wm. Gill, eldest son of Wm. G. of B., gent., matric. from Exeter Coll., Oxf., 1829, aged 18. (Foster.)

191. "Thо. Gill EsQR." "Jac. arm. spade shield on a mantle.

Note by Sir A. W. F.: "Gyll of Barton, co. York. Compare Norcliff.." (F., 11,921.)

ARMs.-Sable, a palet between four fleurs-de-lis Or, a canton Argent.

Cnest.-The head of an Eastern King, couped at the shoulders, crowned, collared, and chained.

Tho. Gyll of Barton died s.p. 1780. (Burke's "Armory.")

192. "Thos. Gill, Juñ. Lambeth" Pict. arm. (F., 11,923.)

The same arms without the canton.

Crest.-On the king's head an antique crown.

193. "Sir Wrlliam Maxnard Gomar" Arm., two oval shields accolé with supporters.

Arus.-Gomm impaling Kerr. (F., 12,141.) ist shield: Argent, a lion rampant, on a chief Gules two seaxes in saltive. Cresr.-Two lions' jambs in saltire erased, each holding a seax. 2nd shield: Gom, impaling, quarterly, 1 and 4, Azure, the sun; 2, Gules, on a chevron Argent thrce mullets ; 3, Salite, on a chevron between three horses' heads erased Argent as many mullets. Supporters: A crusader and nun.

MotToes. - Tria junCta in uno. per costanzl E speranza.

Arms granted 1761. (Burke's "Armory.")

Field Marshal, G.C.B., eldest son of Lieut.-Col. Wm. Gomm by Mary Alleyne, dau. of Joseph Maynard of B., born there 1784, mar. 1st Sophia Penn, who died 1827 , and $21 \mathrm{dly}$, in 1830, Eliz., eldest dau. of Lord Robert Kerr. He commanded the troops in Jamaica 1839-42, and died 1875, aged 90 . ("D.N.B.")

194. "Elliot Grasetr" Arm. (F., 12,5 49 .)

Arus.-Per saltire Ermine and Ermines a saltire Azure, between in chief and base a thistle, and in fess two mullets. MOTTO.-MELIORA SEQUI.

Cress. - $A$ drawn bow erect with arrow fived between two holly leaves. 1800 .

His widow Ann died 1810, aged 71. Their son Rev. Jas. Grusett was born

195. "Henry James Grasett." Arm. (F., 12,550.)

Arms as above.

196. "Mr. Othriel Hagatis, 1723" Printed label. (J.MI.)

Son of O. Haggatt of Bristol and B., merchant, whose will was proved in 1719. $\mathrm{He}$ was Judge of Oistins, M. of C., and died about 1732 . His son Othniel also M. of C. 1726 and Chief Baron of the Court of C.P., died 1735.

197. "Wrlliam Haggatt, Esq." Festoon arm. (F., 13,211.)

Arms.-Quarterly: 1 and 4, Argent, two bends Gules [Haggatr]; 2 and 3, Gules, a chevron between three horses Argent [LAMrberr]; impaling, Argent, guttée de sang, two swords in saltire Gules, over all a lion rampant [W ALTER].

Crest. - - palm tree.

Third son of Nath. Haggatt of B., and Mitcham, co. Surrey, by Jane, dau. of Simon Lambert of Bristol, born 1743, died 1773.

198. "JAMES Ashlex HALL J. Thompson sc." Jac. arm. (F.M.) T'ot in Fincham.

199. "Edward, Lord Harewood" Arm. (F., 17,633.)

Crest, Supporters, and Motto as in pecrage. 
ARMs.- Sable, a cross flory within a bordure Or.

Edward Lascelles, son of Edward Lascelles of B., born 1740, created Baron 1796, died 1820.

200. "Edward, Eart of Harewood" The last plate reworked. (F., 17,634.) Created an Earl in 1812.

201. (Wm. Hawtayne) Anonymous. Wreath and ribbon arm. (F., 14,185.) ARMs.-Or, on a fess cotised Gules, between three hinds' heads erased a unicorn conrant; impaling, Sable, three escallops [? STRICKLAND].

Crest. - A hind's head erased between two rose branches.

202. "William Hillary M.D. Bath 1743. J.S." Early Jac. arm. (F., 14,759.)

Author of "Observations on Diseases in Barbados," 1752. (F.C.) Died 22 A pril 1763.

203. "Benjamin Hivds, Esq ${ }^{\mathrm{R}}$. G. Johnson sc. Bristol." Arm. shield in a garter. (F., 14,821:) Engraved about 1820. (Fincham.)

Arus.-Gules, a chevron $O r$ between three stags tripping.

Crest.-Ont of a coronet a wyern. Motto.-Vigilo Et spero.

Benjamin Hinds was a subseriber 1750 to Hughes" "History of Barbados." Another Benjamin Hinds died 1807, aged 39. (See ante, I., 381.)

204. "Willian Hixds. B. Wyon Sc." Arm. (F., 14,S22.) Engraved about 1S20. (Fincham.)

AnMs.-Or, three pales Azure, on a chief Gules three lions' heads erased.

Crest, - A lion rampant Sable. Motto.-Ut tibi sic alteri.

(See ante, I., 28.)

205. "Isade Hun't of Philadelphia." Printed label.

From Barbados, and father of the late Leigh Hunt. (F.M.)

206. "Valentine JoNes" Arm. (F., 16,715.)

Anus.-Per bend sinister Ermine and Ermines, a lion rampant Argent within a bordure engrailed or; impaling: Or, a fess walled, on a chief Sable three escallops Argent, in base a rose Gules.

Crest.-A boar's head erased. Motto.-DUM spiro speno.

207. ("Valextine Jones, EsQ $Q^{\mathrm{B}}$, in ink.) Anonymous. Chip. arm. (F., 16,728.)

AnMs.-Quarterly : 1 and 4, Or, a lion rampant; 2 and 3, Sable, three horses' heads couped Argent. CREsT.-A lion rampant.

MoTTO.-HEB DDUW HEB DDIM DUW ADIGON.

As this coat differs from No. 16,715, 1 cannot say which relates to the Barbadian family.

Valentine Jones, son of Valentine Jones of St. Michael's, B., esq., matric. from Christ Ch., Oxf., 1800, aged 18, cr. M.A. 1803 ; of Linc. Inn 1799. (Foster.)

208. "Jos. Keeling EsqR." Chip. arm. (F., 16,848.)

A Rus.-Sable, a lion rampant Or, holding an escutcheon Argent, charged with a cross-crosslet fitchy Gules, a crescent for a difference.

CREsT.-Out of a mural coronet a demi-lion rampant holding an escutcheon (as in Arms).

F. 16,8+7, "John Keeling, Esqr", has the same Crest aud Arms, but the cross is pattée fitchée Gules. See the Visitations of London and Staffordshire.

? J.P. for Essex and Middlesex, Collector of Customs at B., and died 1792. 
209. "Robert Loveli." Arm. spade shield.

Arms. - Argent, between three wolves' heads erased Gules, a chevron Sable.

Crest. - $A$ talbot courant Argent.

Of the Cliff estate, B., as son of Philip Lovell matric. from Merton Coll., Ox., 1772, as a commoner, M.D. Edin., settled 1811 in Berkeley Square, Bristol, and purchased the Begbrooke estates three miles from there, where he died 11 April 1823, aged 69, and was buried in the transept of the Cathedral. He was the great-uncle on the mother's side of Mr. Danied Parsons. He mar. Eliz., dau. and heiress of Sam. Osborne, who died 12 May 1830 and was buried near her husband. (E.L.J., xiii., 164.) Philip Lovell, Esq., died in 1823, aged 74, at Frenchay, near Bristol. arm.

210. "The Right Honble. Ladx Mart Low'sher" Wreath and ribbon

Arms.-Lowther impaling Stuart.

Mary, dau, of John, Earl of Bute, mar. 1761 Sir James Lowther, Bart., created Earl of Lonsdale 1784. (F., 18,827.) He died 1802; his estate in B. worth $£ 4,000$ a year. ("G.M.," 587.)

211. "Abraham Mason of Barbadoes" Chip. arm. (F.M.)

212. "William MarnaRd." Arin. spade shield. (F., 20,260.)

Arms.-Argent, a chevron Azure lietween three sin. hands couped Gules.

CREsT.- $A$ stag statant. No motto on label.

Born 1706, mar. Margaret Blackman, and died at Bath 1763. (Ante, I., 24.) The plate may have been used by his family.

213. "John Marnard." Arm. (F., 20,258.)

ArMs as in preceding. CRest.-A stag tripping.

MotTo.-Mands JUSTa vardus.

This plate is in my copy of Caribbeana of 1741 . 1710 .

J. Maynard, elder brother of William, born 1692, was of the Inner Temple

214. "Tirovas Parry. Suffeld Sculp." Arin. (F., 22,805.) Engraved about the year 1830 (Fincham).

Arirs.-Quarterly : 1, Azure, a lion passant guardant $\mathrm{Or}_{\mathrm{r}}$; 2, Argent, a fess between three fleurs-de-lis Sable; 3, A cross fleury couped, between four choughs; 4, Azure, a boar's head couped. A martlet for a difference.

Crest.-A boar's head couped. Motto.-QU正 postulas PRESTes.

215. "Thomas, Barbados B. Wyon sc. London" Arm. (F., 22,806.) No date given by Fincham.

Arms of the See: Azure, a pastoral staff and key in saltire between in chief a royal crown, and in base a mullet of eight points; impaling: PARRY, with a crescent Or for a difference. CREsT.-A mitre.

Tho. Parry, boln 1795, Archdeacon of Antigua 1824, ditto of B. 1840, Bishop of B. 1842 till his death 1870 ("D.N.B.").

216. "Geonge Fitzmaurice Parry Okeden" Crest. (F., 22,241.)

CREST. - A bear's paw erect erased, grasping a branch of oak [OKEDEN].

David Parry, Gov. of B. twelve years, mar. Cath. Jane, only dau. of Edınund Okeden, and their issue inherited the Okeden estates in Dorsetshire.

217. "Daniel Parsons, M.A. E. Coll. B. M. V. Orfel maccexli " Arm. (F., 22,820.)

Arms.-Single coat. No crest. Motro.-Nisi dominus. 
218. "Stuarts Lodge." Written in pencil is "Daniel Parsons of." Arm. about 1837. (F., 22,819.) Also an anonymous plate. (F.C.)

Ariss.-Quarterly : 1 and 4, Gules, two chevronels Ermine between three eagles displayed Or [PAnsons] ; 2 and 3, Quarterly Ermine and Azure, over all a cros.: Or [OsBonNe]; impaling: Or, a tower porte ouverte between three battle. axes erect Sable [HExT].

CRest.-A demi-griffin segreant, couped Argent, beaked and armed Gules.

$\mathrm{He}$ was an authority on bookplates as early as 1869 , mar. 1845, resided at Malvern Wells, and died 5 July 1887, aged 76. In early life he was a clergyman, but joined the Church of Rome after 1837. (Burke's "Armory" and "Landed Gentry." Illustrated in E.L.J., xiii., 163, and E. Castle's "English Bookplates," p. 197.) As son of the Rev. John Parsons of Clifton, he matric. from Oriel Coll., Oxf., in 1828, aged 17, B.A. 1832, M.A. 1835.

219. "Prnder" Wreath and ribbon arm. (F., 23,640.)

ARurs.-Azure, a chevron Argent between three lions' heads erased Ermine, and crowned. CREsT.-A lion's head erased Ermine, crowned.

220. "Rer" Johr Hothersall Pixder" Arm. (F., 23,641.)

Arurs.-Quarterly : 1 and 4, Prnder, but no ermine; 2 and 3, Azure, a leopard rampant guardant [Ho'THERSALL].

M.A. from Caius Coll., Cam., Princiual of Codrington Coll. 18ะ9-35, ditto of Wells Theological Coll. 1810. (Bindley's "Annals of Cod. Coll.," pp. 2S, 32. Ped. of Pindar in Jewers' "Wells Cath. M.I.," p. 27S.) Capt. Tho. Hothersall and Tho. Hothersall, Jr., owned plantations in St. John's parish in 1658.

221. "Chas Pinfold L.L.D." Chip. arm. (F., 23,643; Allen, 683.)

222. "Chas Pinfold, I.L.D." Chip. arm. A different plate. (F., 23,644.)

223. "Chas Pinfold L.L.D. Goterner of Barbados" Chip. arm. The last plate with inscription altered. (F., 23,645; Allen, 65t. Illustrated ante, II., p. 2t1, and in E.L.J., xiii., 152.) Probably the earliest plate. (F.C.)

ARMs.-Azure, on a chevron Or, surmounted by another of the field, betwecn three doves proper as many plates.

Crest.-A stork, in the beak a honeysuckle slipped, all proper.

Govr. $1756-66$, died s.p.1. 1788, aged 79 .

224. "Arabella Pinfold" Arm. lozenge. (F., 23,612.)

The chevron is Argent instead of Or.

Niece of the Governor. Executrix 1806 of her mother Martha.

225. "Loursa Pinfold" Arm. lozenge. (F., 23,646.) The same plate as preceding. Sister of Arabella.

226. "RevD C. J. Pinfold." Arm. The same arms as the Governor. (W.E.B.)

227. "Leighton" Festoon arm. (F., 18,035.)

Arws.-Quarterly indented Or and Gules; impaling: Azure, on a chevron between three doves three hurts [PINFoLd]. No Crest. IIotro.-Dread shame.

Lieut.-Gen. Francis Leighton of Bautsley, co. Montgomery, mar. 1746 Renea, born 1712, dau. of Chas. Pinfold, LL.D.

228. "Francis Rernolds EsQ.". Chip. arin. (F., 21,856.)

ARMs.- Sable, a chevron Argent between three does' heads couped.

Crest. - A doe's head erased.

? M.P. Laucaster, Prov. Marshal of B., and d. 1773. 
229. "JoHN Rice EsQR of BaRBADos 1768" Chip. A vely rare plate, not in Allen nor Hamilton. (J.M.)

Rickexts. See under "Jamaica."

230. "The Hon ${ }^{\mathrm{Be}}$. S". Thos. Robinson of Rookby Park in the County of York BarT. ONe of $\mathrm{T}^{\mathbf{B}}$ Commissioners of His M'stie's Revenue of Excise \& F.R.S. \&c." Jac. arm. (F., 25,308.)

ARMs.-Quarterly: 1, Vert, a chevron charged with the Badge of Ulster, between three roebucks trippant $\mathrm{O}_{r} ; 2$, Azure, a chevron Argent between three choughs [PHILLIPS]; 3, Argent, a fess between six crosses crosslet fitchy Sable [LAтTоN]; 4, Argent, a chevron engrailed between three chessrooks Sable [IVAITER]; impaling, 1, Gules, on a bend between six crosses crosslet fitchée drgent an escutcheon $\mathrm{Or}$, charged with a demi-lion rampant within a double tressurc flory counterflory of the first [HowaRD]; 2, Gules, three lions passant, in chief a label of three points [Brothentox]; 3, Gules, a lion rampant [Mowвrdx]; 4, Gules, three escallops [DACBE].

CREsT.-A roebuck trippant and bezantée.

MotTo.-virtete NoN verbis.

Born 1700, of Rokeby, M.P. 1727, created Bart. 1730, amateur arehitect, ruined by extravagance, Commissioner of Excise 1735-42, Governor of B. 1742, but recalled in 1747, mar. 1stly, in 1728, Eliz., dau. of Charles, 3rd Earl of Carlisle, and widow of Nich., Lord Lechmere, who died 1739; mar. 2ndly, in B., 1743, the widow of Sam. Salmon, a rich ironmonger, and daughter of a Mr. Booth, and died 1777. Monument in Merton Church and Westminster Abbey. ("D.N.B.")

This plate and a larger one are illustrated in Howard's "Baronets' Bookplates." The arms on the larger are-Quarterly of nine: 1, RoBINson; 2, Phillips ; 3, Strangways; 4, Layton; 5 , Green; 6 , Massingberd ; 7, Boxville; 8, WALTER; 9, ShaWE; impaling, Quarterly of six: 1, Howard; 2, Brotherton ; 3 , Warren ; 4, Mowbrax ; 5 , Dacre; 6, Greystoke. (F.C.)

231. "Thomas Robinson, of Rookby in tile county of Tork Esq" Jac. arm. Supporters. (F., 25,307.)

ARars.-Purpure, on a chevron between three roebucks trippant as many quatrefoils Gules. Crest as above. Motro.-Sola in DEO Salus.

232. "Willian H. Shate" Arm. (F., 25,925.)

Arms.-Gules, on a chevron Argent three nen's heads affrontée, bearded and couped. Crest.-A like head.

MotTo.-FACta NoN VERBa.

Wm. Hood Sage, only son of Charles Fred. Sage of B., b. 1827, B.A. Oxf., Vicar of St. Michael, near Bristol, d. 1874. (Foster.)

233. "RICH ${ }^{\mathrm{D}}$. Salter EsQR Barbados" Jac. arm. These seem to be the arms of Watson. (F., 26,006; Allen, 754; E.L.J., xviii., 88.)

AnMs.-Argent, on a chevron engrailed Azure between three choughs as many crescents.

CRestr.-A lion rampant.

He was a subscriber to Barbados Acts in 1764. (F.C.)

234. " $R^{\text {D ScotT EsQ }}{ }^{\mathrm{R}}$." Chip. arm. (F., 26,308.)

ArMs.-Gules, three catherine wheels. CREsT.-Ademi-griffin segreant, couped.

MotTo.-ReCte FACIENDo NeMinem timeas.

The Scotts of B. bore the above arms.

235. "Јонм Soвer." Chip. arm. (F., 27,560.)

ARurs.-Ermine, a saltire Gules, and on a chief Sable three crescents Or.

CREST.-Out of a crescent Or a lion's head Gules.

Born 1715, of Little Bursted, co. Essex, and died in 1763, leaving a son John, born 1739, of Queen's Coll., Oxf., 1756. 
236. "William Spry. W. Smith, sculp" (of U.S.A.). Chip. arm. (Allen, 817.) Pict. Chip. and engraved about 1770. (Fincham.)

ARMs.-Argent, two bars and a chevron in chief Or, a crescent for a difference.

CREST.-A dove standing on a serpent.

Governor of B. 1767 and died 1772. (IV.E.B.) Probably of the Cornish family, but he is not in the pedigree. In his will he only names his wife Cath. and his two sisters, Jane and Mary spry.

There are two states of this plate. 'The earlier has "Wm Spry " written in ink, and the later has the Crest reworked and the name engraved. On 19 Dec. 1912 Mr. Cattle and I saw a Chip. pict. plate in the Ponsonby Collection with "Horatio Spry" written in ink. Horatio, born 1730, Lient.-Gen. 1801, died 1811. His brother Wm. a Lient.-Gen. 1799, died 1802. (Vivian's "Visit. of Corn.," 436.) Dr. E. Spry (F., 27,767) has the same coat. (F.C.)

237. "Thomas Tunckes of Barbados, Ese ${ }^{\mathrm{R}}$ " Chip. arm. Arms.-Tunckes with Fetherstou on an escutcheon, impaling . . . . (F., 29,951.)

AxMs.-Quarterly: 1 and 4, Azure, two bendlets Argent; 2 and 3, Azure, a chevron Argent, between in chief two annulets, and in base a... Or. On an inescutcheon: Gules, a chevron between three ostrich feathers Or; impaling: Gules, a fess Or between three martlets crowned in chief and two in base.

Crest.- Ont of a coronet two garbs, one in each bend.

MotTo.-ESSE QUaM VIDERI.

Mrs. Katl. 'Tunkes, widow, sister of John Pare, by her will, dated 1777. demised her plantation of 319 acres in B., called Waterford alias Forestalles alias T'unkes, to her niece Mrs. Rachel Walner of Antigua.

238. "Tho Waterajan Esq ${ }^{\mathrm{E}}$ of Chalky Mount, Barbadoes" Chip. engraved label. (W.E.B.)

239. "Natiraniel Weekes" Chip. arm. (F., 31,232.)

ARMs.-Paly of six Gules and Or, on a chief Azure three engles displayed.

C'REsT. - A demi-lion rampant, couped. МотTо.-EST HIC.

Judge of Vice-Chancellor Compt 1790. (TV.E.B.) Rebecen Ann, his widow, died at Sidmouth 12 Dec. 1846, aged 73. Ralph, son of Nath. W., matric. 1759, aged 18, and Nath., son of Nath., in 1782, aged 21. (Foster.)

240. "Johr Wilson. Barbados" Pict. arm. (F., 32,098; Allen, 947.)

Arus.-Per pale Argent and dzure, three lions' gambs erased, counterchanged.

CREST.-A griffin passant. W.I. seascape.

"Peter Wilsox." F'estoon arn. (F., 32,120.) Arus as in preceding.

241. "Dudleius Woodbridge Argeus Americands 17(40)." Jac. am. (J.M.) (Illustrated in E.I.J., xiv., 123, 137 ; not in F., Allen nor Hamilton.)

ARMs.-Argent, on a bend Gules three chaplets of roses proper.

CREst. $-A$ chaplet of roses proper. MotTto.-VIRTUS SE CORONat.

Dudley Woodbridge, Director General of the R. Assiento Co. in B., Judge Advocate and Agent of the South Sea Co., died 11 Feb. 1720 (Hist. Regr., 9). His portrait in mezzotint by Smith, after Kneller, was published in 1718 (Maggs Bros.) See "D.N.B." The Rev. Dudley W., probably his son, Rector of St. Plitip's in B., made his will in 1747, and proved 1750 (65, Greenly). His first wife died 1747 , and he then mar. Ruth, dau. of Mrs. Susannah Haggatt.

24.2. "Library Association. Barbados. Established Feb 10 Label. (W.E.B.)

243. "The Literary Society in Barbados commenced A.-D. Mdeclixirit Trotter Sc." Pictorial. Eugraved in 1800. (E.L.J., xiii., 150.) The design has been taken from an old seal of the I. In the centre of a circle is a ship in sail. Above is "AD OCCIDENTEM," and below "ARTIBUS, INGENUIS, RELIGIONE, FIDE." Illustrated in Fincham, p. 98. 


\section{Bermulda}

244. "Sir Thomas Harter" Arm., two shields accolé. (F., 14,020.)

Arus.-No. 1 shield: Azure, on a chevron enbattled Or, bctreen two bear's' gambs erased in chief and an anchor erect in base, a bomb on firc between two cresccnts Sab7e; on a canton of the second a spirig of oak with the badge of the Bath. No. 2 shield: HARTEY impaling Argent, on a chevron embattled Gules between three bear's' gambs erased Ermines as many crescents Ermine [HARTIY of Eastry]. Motto.-persevere.

CREST. - Two bears' gambs erased Sable, the paws supporting a crescent Or, around the whole a wreath of laurel leaves.

Borm 1775 (fourth son of Admiral Sir Henry Harvey, who captured Trinidad 1797, and died 1810). Vice-Admiral and K.C.B. 1833, C.-in-C. in the W.I. and N. America. He married 1805 Sarah, dau. of Capt. Jolin Harvey, and died 1841, aged 65, at the Admiralty House, B. ("D.N.B.")

245. "Lt General Sir Henry Leferoy" Arm. (Not in F.)

Arus.-Qnarterly : 1 and 4, Tert, fretty Argent, on a chief of the second a cop between two wyverns Gules [LEFROT]; 2 and 3, Azure, a chevron Or between three crescents, on a chief Gulcs three mullets pierced Argent; impaling; Argent, a lion rampant Gules. Crest.-A demi-wyvern couped.

Motro.-mutare sperno. Pendent are two badges.

John Henry Lefroy, born 1817, entered the R.A. 1834, Gorernor of B. 1871 -77, K.C.M.G. 1877, Governor of Tasmania 1880.1, mar. 1st . . . Robinson; 2ndly, ... D. Dundas, and died 1890 ("D.N.B."). Author of a History of B., two vols., 1877, of which I have a copy with his bookplate.

246. "Wiluiam Lumlex. Suffield sculpt." Arm. (F., 18,906.) Engraved abont $1810 . \quad$ (Fincham.)

ArMs.-Argent, a fess Gules between three parrots.

CREst. - A pelican with wings expanded in her nest feeding three young.

MotTo.- MURUS eneus CONSCIENTIA sana.

Seventh son of Richard, 4th Farl of Scarborongh, born 1769. General, Governor of B. 1819, G.C.B., mar. 1st, in 1804, Mary Sutherland, who died 1807; 2ndly, in 1817, Louisa Margaret, widow of Col. Lyuch Cotton, and died 1850.

247. "James Pérot." Early Chip. (Illustrated in F.L.J., xv., 21.)

"James Perrot" (F., 23,346) has the same arms, crest, and motto.

248. "Duncan Strewart." Chip. arm., spade shield. (F., 28,149.)

ArMs.-Quarterly : 1 and 4, Or, a fess counter-compony Argent and Azure; 2 and 3, Argent, a lymphad Sable.

Crest. - A horse's head couped. Motto.-WHither will ye.

Collector of Customs at New London, Conn., afterwards at Bermuda, and died in London 1793. (F.C.) Styled of Ardstreal in the "G.M.," p. 867.

249. "Wm. Territe LLD." Arm. spade shield. (F., 29,130.)

ARMrs. - Gules, three towers. No Crest nor Motto.

Judge of the Vice-Admiralty, B., mar. there 1810 Anne Cath. Parkyns, niece of Vice-Admiral Sir Johu Borlase Warren, Bart. 


\section{画omíníra,}

250. "William Blaxc. Middle Tempete. Dominica." Crest in a garter. (F., 2774; Allen, 83.)

Crest.-A stag's head erased. Motto.-Frangas NoN flectas.

251. "Janes Laing." Arm. (F., 17,413.)

Anus.-Argent, three piles Sable; impaling: Argent, a fess ehecky Argent and Azure.

Crest.-A cock. Motto.-vigilance.

"Sketches and Recollections of the W.I." was dedicated in 1828 to him as of Streatham Hill, formerly of D. His wife Eliza died 1816, aged 61, and his son Allan Stewart Laing, of Trin. Coll., Oxf., matric. 1S05, aged 17, and died 1862.

252. "Charles Colemar Tahíg" Arm. (F., 17,412.)

Arms of Laing. C. J. Coleman died at D. 1810.

253. "Thomas Yeo. J: Kirk Se: St Pauls Church Iard" Chip. arm. (F., 32,853.) No date given by Fincham.

ArMs.-Argent, a chevron Sable between three drakes. CREST.-A peacock.

A ppointed Solicitor-General 1778. Mr. F. C. has a "John Yeo." Chip., same coat, not signed.

254. "Tחos YEo." Chip. arm. A different plate. (F.C.)

Young. See "Antigua."

\section{Eremata.}

255. "Charles Ashwelt, of Grenada" Arm. spade shield. (F., S38; Allen, 34.)

Arus.-Azure, three griffins' heads couped. Crest. - A lion couchant.

Secretary of St. Vincent 1783, mar. 1792 Fanny Whitehouse, and died 1798, arged 42. See ante, 20.

256. "Joseph Beete, Grenada" Spade shield (?). (W.E.B.)

See this name under "British Guiana."

257. "Doctor Fraxcts Burke of the Island of Grenada. Axwo Dom. 17 .." Printed label. (F.M.)

258. "Chas Snell Cirauncr" Festoon arm. (F., 5656. Illustrated in Howard"s "Misc. Gen. et Her.," 2nd Ser., i., 28.)

Arms.-Gules, a cross patonce Argent, on a chief Azure a lion passant of the second.

Crest.-Out of a coronet a demi-griffin with wings displayed, paly Azure and Gules.

Born 1759, of Theobalds, co. Herts. On the death of his father Wm. Snell in 1779 he inherited Snell Hall and Broomfield in G.; mar. 1781 Amelia, dau. and coh. of Nath. Chauncy of London, and died 1809.

259. "Hugh Dalrmmpe EsQR" Chip. arm. (F., 7870.)

Arus.-Or, a saltire Azure lozengy of the first, a mullet for a difference, within a bordure of the second, charged with six mullets and six boars' heads couped alternately. CREST.-A rock.

Attorney-General of G., where he died 1774. 
GRENADA.

260. "Alexr. Dalmyarpe EsQR" (F., 7860.) The same design, but with a reserve added below for the name. An annulet for a difference.

261. "James Widdrimgton Shand Harvey, of Castle Semple." Arm. $(\mathrm{F}, 14,000$.)

AnMs.-Quarterly of 16: 1, Gules, on a bend three trefoils Vert, on a chief Argent a stag's hiead cabossed betueen two mullets of the first [HARTEY]; 2, Azure, a boar's head erased, on a chief Arqent three mullets Gules [SHand] 3, Vert, between three stugs trippant Or, on a cherron of the second threc quatrcfoils Gules [? RAE]; 4, Vert, a rose within two equilateral triangles interlaced between two mullets Argent; 5, Argent, three escutcheons Gules [H从Y]; 6, Argent, in chief two sinister hands Gules, and in base a lion rampant Sable within a bordure engrailed Azure; 7, Or, three human hearts Gules; 8, Argent, a cherron Sable between three mullets pierced Gules; 9, Azure, three boars' heads erased Or; 10, Sable, a fess Ermine between three crescents Argent [LEL], imnaling, Quarterly Argent and Gules, a bend Sable; 11, Argcnt, between three bunches of three holly leaves proper, on a fess Azure three mullets Argent; 12, Azure, a tower on a rock; 13, Gules, a wild boar Or; 14, Gules, a fess checky Argent and Azure between in chief three cinquefoils and in base a mascle; 15, Argent, between two barrulets Azwre, on a fess Azure the sun; 16, Gules, a lion rampant Argent.

Crests. - 1. A dove flying, in its mouth a sprig. MotTo.-VIRTCTE DUCE COMtTe Fortuna [SHAND]. 2. Issuant out of a crescent Or, thereon a buck's head cabossed, a hand erect charged with an ermine spot and holding a trefoil. Motto.- omnia bene [Hanvey]. 3. A bull's head erased Sable. Motto.JOYE SANS FIN.

Born 1853, and assumed the name and arms of Harvey in 1883. See pedigree in "Antigua," ii., 68.

262. "WiLL": L: Leyborne" Festoon arm. (F., 18,274.)

ARMs.-Azure, six lions rampant, 3, 2 and 1 .

Crest.-An eagle vith wings expanded. No Motto.

Governor of G. 1772, mar. Anne Popham of Littlecote, co. Wilts, and died 1775. I saw his arms in a window in the manor house of Littlecote in 1912.

263. "Agnes Mo Burnie, Grenada." Wreath and ribbon engraved label, 1810 watermark. (F., 19,092.)

264. "Charles Marryat" Arm. (F., 19,756).

Arms and Crest of Marryat. Motto.-Fortuna superanda Ferendo.

265. "Joseph Marryat" Arm. (F., 19,759. Illustrated in E.L.J., xiv., 35, and Howard's "Misc. Gen. et Her.," 4th Ser., iii., 342.)

ArMs.-Barry of six Or and Sable, on a canton of the second a fleur-de-lis of the first.

CREST.-On a coronet a ram's head.

Born 1757, M.P., Chairman of Lloyd's, Colonial Agent for G., in. 1788 Charlotte von Geyer of Boston, Mass., and died 1824.

266. "Charlotte Marriat" Arm. lozenge. (F., 19,757.)

Anus.-Marryat, impaling: Gules, a vultuve with expanded wings Argent [VON GEYER].

Widow of Joseph, and died 1854.

267. "George Gun Munro, Grenada" Arm. Arms.-Munro quartering Gun and Poyntz. (F., 21,339.)

ARMs.-Quarterly : 1 and 4, Or, an eagle's head erased; 2, Argent, a stip in sail, on a chief Gules between two mullets Argent three legs conjoined; 3, Barry of eight $O r$ and Gules. 
Crest.-An eagle with wings expanded. Motto.-DREaD GoD.

The Munros were merchants of G., one of whom, Robert, died 1771.

"T. M. Munro, M.D." Arm. (F., 21,344.)

The same arms and motto. Crest.-An eagle close.

268. "Samuel Amy Severne, Esq. Wallop Hatu, Co. Salop \& Thenford, co. Northamptov" Arm. Engraved by Appelby for Burke's "Heraldic Illustrations," plate 60. (F., 26,498.)

Arus.-Argent, on a chevron Sable nine bezants. Crest.-A cinquefoil Or.

Motto.-TiRtus prastantior a ERo.

Born 1772, Sheriff of Montgomeryshire 1824 and Northamptonshire 1829 , leased in 1839 his plantation called New Hampshire of 320 acres to George Edw. Anson, and died 1845.

269. "Alexander Udny, Esq?. 1726. M. L.f." Jac. arm. (F., 30,148.) Not in Fincham.

AnMs.-Gules, two greyhound's connter-salient collared, in chief a stag's head couped, facing sinister, between three fleurs-de-lis Or. CREsT-A flcur-de-lis. Supporters: Two savages wreathed about the head and loins with laurel, in each outer hand a club.

МотTO.-ALL MIY HOPE IS IN GOD.

No. 30,149, Chip., has the same coat, the stag's bead facing dexter.

270. “J. H. UDNY OF UDNY" Arm. (F., 30,151.)

Arms of Udney (the stag's head cabossed), impaling: Ermine, on a chief Gules three martlets [FiтzнuGா]. Crest, Motto, and Supporters.

John Rob. Fullarton Udny mar. 1stly, in 1812, Emily, dau. of Tho. Fitzhugh of Plâs Power, co. Denbigh.

Ernest Udny born 1732, died in G. ("Genealogist," ii., 89.)

Rob. Fullarton Udny of Udny Castle, Aberdeenshire, was a W.I. merchant, born 1725 , second son of Jas. Udny, and died 1802 . Will as of G. (67, Kenyon). His dau. Mary mar. Sir Wm. Cunynghame. ("Home Counties Mag.," i., 273.)

271. "M. Generat Sir Geo: Townsmend WadKer, G.C.B. \& K.C.T. \& S." Arm., two shields accolé with supporters. (F., 30,592.)

Arus.-I. Erminois, on a pile embattled Azure a mural crown with вaDaJos on it between two galtraps in pale $O_{r}$. JI. WhLKER, impaling, Ermine, between three leopards' heads cabossed a chevron Gules [ALIEN]. Supporters and Motto as in Burke's "Armor"v."

Crest.-An ostricti in a mural croun, its dexter foot on a grenade.

He mar. 1stly, in 1789. Anna, dau. of Richard Allen of Bury, co. Lane., and 2ndly in 1820. G.C.B. 1817, Governor of G. 1815. An altered plate has "Lt General." (F., 30,593.)

\section{Guadalotupe.}

272. (General Dundas) "Governor of Guadaloupe." Anonymous. Chip. (W.E.B.)

Major-Gen. Thomas Dundas, born 1750, died 3 June 1794, and was buried in Fort Matilda. ("G.M.," 1843, p. 155, and "D.N.B.")

273. "James Elmx, Beccles, Suffotк, 1757 Polak Sculp." Arm. (Hamilton's "Dated Bookplates.") First state. Polak signed Dutch bookplates. (Fincham.)

A tanner, emigrated to G., where he died. 
274. "Janes Elirt. Guadaloupe. Jutr 1"st 1760. Polak sculp." Chip" arm. Second state. (E.L.J., xv., 116, 137.) (W.E.B.)

Anus.-Ermine, two bar's Sable, each charged with five elm leavcs Or.

Crest. - $A$ mermaid.

Sarah, his dau., mar. at Beccles, 1783, Geo. Crabbe, the poet.

275. "Robert Melvili EsQR." Chip. arm. (W.E.B.) "Of Strathkinnefs" in ink in my copy.

Anus.-Gules, three crescents Argent within a bordure of the second, charged with eight cinquefoils of the first, a crescent for a difference. $\mathrm{C}_{\mathrm{R}} \mathrm{EST}$. $-A$ crescent.

Motto.-Denique CoElum.

Born 1723. As a Major served with the 3Sth Reg. at Antigua 1756, Lieut.Col. and Lieut.-Governor G. 1759, Governor 1760, and of the Ceded I. 1763-69. Twelve years later with Sir Wm. Young serred on a mission to Paris for T'obago. Founded the Botanic Garden at St. Vincent. LL.D., F.R.S., F.S.A. Invented carronades. Died 1809 , being then the oldest general. ("D.N.B.")

\section{Butitigl) Guina.}

276. (Austin) "Bisiop of Gutara (B. Wyon $s c$ )." Arm. (F., 996.) Engraved soon after 1S42, when the See was founded.

Arms.-Argent, "long cross Azure surmounted of a small one Or, on a chief Gules a lion passant requardant holding a pastoral staff [SEE], impaling, Gules, on a chevron engraited Or, between three long crosses of the second, as many lions heads erased of the first [A Ustis]. CREss.-A Aritre.

William Piercy Austin was of Exeter Coll., Oxf., matric. 1825, aged 17, B.A. 1829, M.A. 1835, D.D. 1842, then Bishop of G., Primate of W.I. 1883. (Foster.)

277. "Joseph Beete. Demerary." Plain arm. spade shield. The arms and crest are those of Wall of Preston. (F., 2046; Allen, 70.)

Died 1815, aged 60. (Ante, II., 233.) See under "Grenada."

Arms.-Argent, a bend Gules between three boars' heads couped Sable.

Crest.-A boar's head couped Sable, holding in its mouth a sprig of oak with oak apples. MotTo.-FORTUNA PERIIT, HoNestas MANE'.

278. "Thomas Buake. Demerarr. J. Smith Sculp. 65 Holborn London." Arm. (W.E.B.)

279. "J. Henry H. Holmes" ? Governor, circa 1830. (W.E.B.)

Not in the Colonial Office List.

280. "Sir James Carmichael Shyth, Bart" Arm. supporters. (F., $27,473$.

Anuss.-Quarterly, 1 and 4, Argent, a fess tortilé within a bordure Azure [CARMICHaEL]; 2 and 3, Azure, a cup, flames issuing therefrom between two chessrooks, within a liordure Or [SмYтiL]. On an inescutcheon: Argent, a battleaxe in palc proper between three pellets [MonsE]. Badge of Ulster.

CREst.-A cubit arm mailed erect couped, in the hand a broken tilting spear.

Dexter Supporter: A lknight in complete armour. Sinister supporter : $A$ horse furnished. Mo'To.-Toujours PREST. Three badges pendent.

F., 5164, anonymous, has the arms of Carmichael and Smyth quarterly.

Born 1780, mar. 1816 Harriet, dau. and heiress of General Rob. Morse, ereated a Baronet 1821, of Nutwood, Surrey, K.C.H., C.B., K.M.T. and K. St. WV., Grovernor 1833 until his death at Georgetown 1838, aged 58. (Archer, 425.) 
Arrs.-Azure, in chief the sun in its glory, in base a crescent Or, a mullet for a differcnce. CRest.-An eagle's head erased Or.

The same plate as Henry Bowles and Harry Bowles. (F.C.) 330.)

Probably of co. Wilts and owner of a plantation in J. in 1771. (Ante, II.,

313. "JosepH Brissetr" Spade arm.

Arus.-Gules, three swords in pale Argent, hilts and pommels Or, hilts meeting in fesse point.

CREsts.-On the dexter a demi-battle-axe erect, and on the sinister a boar's head couped. MotTo.-SPERAT ET AUDET.

Of Hanover, J., died 1807. (E. E. West.)

314. "Francis Rigbi Brodbelt, M.D." Chip. arm. (F., 3802.)

AnMs.-Argent, three bendlets. CREst.-A double-headed eagle displayed.

MotTo.-ALTIUS IBUNT QUI AD SUMMa NITANTUR.

G. C. Peachey gives the date as about 1750. (E.L.J., xi., 23.)

Son of Daniel B. of Nevis and later of J. Bapt. 1746 and died 1795. The arms on his monument are Gules, three bendlets wavy Or, and the Crest is Or. (Roby.)

315. "Francis Rigbi Brodbelt M.D." Festoon arm.

Ariss.-? Argent, three bendlets wavy Or. Crest and Motto as above. (Illustrated in F.L.J., xv., 2.)

316. Thomas Lee Brodbelt, M.D. Crest. (F., 3804.)

Crest and Motto as above. Perhaps related to the above.

317. (Brodbelt). Anonymous. Arm. (F., 3803.)

Arms of Brodbelt with fifteen quarterings. (Illustrated in E.L.J., v., 197 and 218.)

I cannot say if this relates to $\mathrm{J}$.

318. "EDWard ButLock" Arm. spade shield. (F., 4312.)

Arus.-Gules, a chevron Ermine between three bullocks' heads cabossed.

CREst.-Five Lochaber axes bound with an escarf:

MOTTO.-NIL CONSCIRE SIBE.

Barrister, mar. 2ndly in 1769 Eliz. Savile Trower, and died 1771. His son of the same names was of Upper Bedford Place, and mar. 1796 Dorothy Harrison.

319. "Sir Williali Burnaby BarT." Arm. spade shield. (F., 4440.)

Anus.-Argent, two bars Gules, in chief a lion passant guardant per pale of the second and Azure. The badge of Ulster.

Crest. - Out of a naval crown a demi-lion rampant guardant, in the dexter paw a staff, thereon a flag Gules. A dolphin and cannon support the shield on each side.

MotTo.-Pro REGE. Another state has the lion all Gules. (F.C.)

Of Broughton Hall, co. Oxford. As Capt. R.N. knighted 1754, Admiral and Commander-in-Chief at the Leeward Islands, later at J., created a baronet 1767, mar. 1stly Margaret, widow of Timothy Donovan of J., and 2ndly Grace, dau. of Drewry Ottley of St. Kitts, and died 1777, being succeeded by his eldest son Sir William Chaloner Burnaby, Capt. R.N., who mar. 1783 Eliz., second dau. of Crisp Molyneux of St. Kitts and Garboldisham, co. Norfolk, and died 1794.

320. "Henry Byndloss" Jac. (J.M.)

Attorney-Gen. of J., bap. 1703, mar. 1751 Jane Cussans, and died 1755. 
321. "Colix Campbeli Esq $Q^{R}$ of Westuoreland, JaMaica" Jac. arm. (F., 49S3.)

ARsrs.-Gyronny of eight Or and Sable, within a bordure divided as the gyronny of eight Purpure and Ermine. CREST.-A hand couped holding u spur.

MotTo.-FORGET NOT.

His will was proved in 1752 . See ante, p. 36, for these arms.

322. "Domald Campbell. Jamaica." Pict. arm. The shield fixed to the mast of a Irmphad (the crest of this family). Motro.-FIt via vi. (Allen, 134.)

M. of A. 17 S3, Speaker 1797, mar. Fra. Gent, widow of Ballard Beckford. (Feurtado.)

323. "Johy Campbell Esq ${ }^{\mathrm{B}}$ of Orange Bay, Jamaica" Wreath and ribbon. (IV.E.B.)

Died 1808, aged 76, and his estates passed to his nephew John Blagrove.

324. "Michael Benignes Clare M.D." Arm. (F., 5867.)

Arus.-Quarterly: 1 and 4, Or, three chevrons Gules within a bordure engrailed Azure; '2 and 3, Or, a chevron between two lions passant in chief and an annulet in base Sable [TAYLOR]; impaling: Or, a wall in fess masoned proper, the top broken, in base a rose Gules, on a chief Sable three escallops, the whole within a bordure Gules [GrahaM]. Crest.-A sun in his glory.

MotTo.-CLareo Foveoque.

Physician-Gen. of J. 1817, K.B. 1822, M. of C., mar. 1817 Margaret, eldest dau. of Col. C. D. Graham, Lieut.-Gov. of St. Mawes, and died 1832, aged 55.

325. "M[r EDward Clarke" Arm. (F., 5919.)

Anjrs.-Quarterly: 1 and 4, Azure, three escallops in pale between two faunches Ermine; 2, Azure, a chevron Or between three lozenges Argent [HYDE]; 3, Sable, a bend sinister Argent between six crosses-crosslet fitchy [LAKE] ; impaling, Azure, a dexter arm in fesse issuing from the sinister fesse point, the hand grasping a sword erect, in chief two mullets Argent [Prevost]. CRest.-A pheon.

Of the Hyde plantation in Trelawny, born 1770, mar. 1st Anne Margaret Prevost who died 1821, and died 1826.

326. "Elizabeth Clarke." Arm. (F., 5922.) About 1840 . (F.C.)

AnMrs.-Clarke quartering Hyde, the lozenges being $O r$.

MotTo.--SOYEZ FERME.

Younger dau. of Geo. C. of J. and New York, born 1805, and died 1881.

327. "Srmon Cranke" Wreath and ribbon arm. (F., 5964.)

ARMs.-Gules, three swords erect in fess.

CREST. - A cubit arm couped, in the hand a sword.

Graduated 1751 at Leyden, succeeded as 7th Bart. Will proved 1783.

328. "MI. Concanen JUN ${ }^{\mathrm{B}} "$ Arm. (F., 6598.)

ARis.-Argent, a tree between three crosses-crosslet fitchy, a martlet for a difference. CREST.-An elephant. MotTo.-JUS FASQUE SEQUENDo.

Mathew Concanen, Attorney-Gen. of J., died 1749, and the above was probably a descendant.

329. "Exre Coote, Esq ${ }^{\mathrm{B}}$ " Arm. spade shield. (F., 6812.)

ARirs.-Argent, a chevron between three cootes proper.

Crest. $-A$ coote proper.

Мотto.-vincit veritas. 6810 and 6811 have the same Arms, Crest, and Motto. 
298. "John Hrnes De LA Beche. Barnes and Co. Coventry Street" Arm. (F., 8377.) Not in Fincham.

Arurs.-Quarterly: 1, Vairé Argent and Gules, on a canton Azure a mullet pierced Or [BEACH] ; 2, Vaivé Azure and Or, a pale Ermine, in chief Argont two chaplets, a crescent for a difference; 3 , Vert, a tower supported by two lions com. battant $O r$ [HrNes]; 4, Or, a lion rampant reguardant, on a canton Sable an eagle's head erased.

CREST.-A demi-lion rampant couped, charged with a mullet and crescent and gorged with a coronet, in its paws a shield of Azure, a pile Or.

Motto.-garde la For. (See Archer, 97, 302.)

Younger son of Tho. Beach, Chief Justice of J., by Helen, dau. and coheiress of John Hynes, born 1765, died 1803.

299. (Beckford). Anonymous. Jac. arm. (F., 1999.)

Arms and Crest of $B$.

Motto.-Cassis tutissima virtus.

300. "Eliz ${ }^{\mathrm{TH}}$ Beckford" Chip. arm. (F., 1996.)

Arus. - Beckfond, but with ouly one eagle on the chevron. On an inescutcheon: Argent three bars Gules, in chief as many martlets [C.ARRILI].

(Beckford). Anonymous. "John Boydell excudit 1778." Festoon arm. Not a bookplate. (F., 2000.)

ArMs.-BECkFord, impaling: Argent, three shields Gules [HAx]. Crest of Beckford.

This shield has been cut from a set of six engraved riews in J., published by Boydell, and dedicated to Wm. Beckford of Somerly and J.

In the "Ex Libris Journal," vol. xvii., pp. 146, 164, is an article on an old book which belonged to an 18th century silversmith. Amongst the illustrations given is a shield with the arms of Beckford impaling Hay, which has evidently been obtained by taking an impression with printers' ink from a piece of plate, so that the arms appear reversed. Both shields belonged to $\mathrm{Wm}$. Beckford of Somerly, natural son of Richard B. of J. by Eliz. Hay. He was born 1744, mar. before 1769 his first-cousin Charlotte, dau. of Tho. Hay, Secretary of J., and died 1799. (Ante, I., 95, 186, 323.)

301. "Fras Love BeckFord" Arm. (F. 1997.)

Arus.-Quarterly: 1 and 4, per pale Gules and Azure, on a chevron Argent, between three martlets Or, as many eagles displayed Sable [BEсKFoRD]; 2 and 3, Argent, three bars Gules, in chief as many lions' heads erased [LotE]. On an inescutcheon: Argent, on a chief embattled three bezants [LEIGH].

CREsT.-A heron's head erased, in the beak a fish.

Of Basing Park, co. Hants, boru 1761, mar. 1788 Johamna, dau. and coheir of John Leigh of Northcourt House, Isle of Wight, and widow of Rich. Bennett Lloyd, and died 1838. See No. 2S4, ante.

302. "William Beckford" Arm. plain shield. (F., 1998.)

Arms.-Quarterly : 1 and 4, BeckFord ; 2, Love; 3, Leigh, impaling: 1 and 4, Argent, a bend cotised Sable [STane]; 2 and 3, Or, on a fess Sable throe plates [Bramston]. Crest of Beckford. Motro.-vivaM UT Telim.

Of Hatchford, co. Surrey, son of Fra. Lore Beckford, mar. 1822 Maria Eliz., only dau. of the Rer. John Bramston-Stone of Forest Hall, co. Essex.

303. "E. Erfinghax" Chip. arm. lozenge. (F., 15,493.)

Arms.-Quarterly: 1, Gules, on a bend Argent between three crosses-crosslet Sable....* [Howard]; 2, Gules, three lions passant guavdant [BRothertor];

* Some charge, indefinable, within a tressure. In No. 304 this is an escutcheon charged with a demi-lion rampant Sable, without a tressure. (F.C.) 
3, Checky Or and Azure [W.RREx]; 4, Gules, a lion rampant, a label of three points, a mullet in centre point [MOWBRAT], impaling BECKFORD (with one eagle on the chevron). Supporters: Two lions rampant, each charged with a mullet. An Earl's coronet.

Eliz., dau. of Peter Beckford, the Speaker, born 1726, mar. 1744-5 Tho., the 2nd Earl, who died 1763. She remar. F.-M. the Hon. Sir Geo. Howard, LL.D. (F., 15,511.) Thomas, Lord Howard, her first husband, also had a bookplateJacobear, with supporters. (F.C.)

301. "Katherine, Countess of Effingham" Chip. arm. (F., 15,494.) Anus.-Quarterly, four coats as above, impaling: Argent, a chevron Gules between ten crosses-crosslet Sable, six and four [Proctor].

CREst.-On a chapeau Gules turned up Ermine a lion statant guardant, the tail extended. MotTo.-viRTus MILLE scuta.

No. 15,495 is green.

A dau. of Metcalfe Proctor of Thorpe, Yorkshire, mar. 1765 Tho., 3rd Earl, who was Governor of J. in 1790. They both died in 1791, and a public monument was erected iu Spanish Town Cathedral. (Cundall's "Sculpture in Jamaica," 13.)

305. "BeLMore." Arm.

2nd Earl, Governor of J. 1829-32. Born 1774, died 1841. (W.E.B.)

306. (Bensor). Anonymous. "Ross sc." Spade pict. arm. In ink: "Granted to Moses Benson of Liverpool, formerly of Jamaica." (W.E.B. See E.L.J., v., 136.) Engraved about 1800. (Fincham.)

307. "John Blaqrove, EsQ " Arm. spade shield. (F., 2734.) A very large plate.

ARMs.-Or, on a bend Sable three leg and thigh pieces of armour.

CREsT.-A palm tree with cocoa nuts. F. 2735 is a smaller size.

Son of John Blagrove, who died 1766. Born 1754, of Cardiff Hall, J., and Ankerwyke House, co. Bucks, mar. 1777 Ann, second dau. of John Shakespear, alderman of London, and died 1824.

308. "A. R. Blake of Lincolns InN" Arm. (F., 2752.)

ARMs.-Argent, a fret Gules. On an inescutcheon: Azure, on a chevron Or between three lions passant guardant as many escallops Gules [JAMEs].

Crest.-A leopard passant guardant. MotTo.-virtus sola nobimitas.

? James of J. (F.C.)

309. "E. F. Botrke" Festoon arm. (F., 3203.)

ARMs.-Or, a cross Gules, in the first quarter a lion rampant.

CREST.-A cat o' mountain sejant guardant, collared and roped.

МотT0.-A CRUCE SALUS.

310. "Eduund F. Bourke" Arm. (F., 3204.)

Arms, Crest, and Motto of Bourke.

311. "Edmund F. Bodrke T. Welch se." Arm. (F., 3205.) Engraved about 1820 . (Fincham.)

Arms.-Quarterly: 1 and 4, BovRke; 2 and 3, Per pale Argent and Gules, a lion rampant between three fleurs-de-lis counterchanged [GOODWYN].

Crest and Motto of Bourke.

Edmund Fearon Bourlze, M. for Clarendon 1779, mar. Mary, who died 1800 , aged 37 , and be in 1812, aged 57 .

312. "ChA Bowles" (by R. M.). Chip. arm. 
281. "J. Teschemaker. L.L.D." Arm. (F. 29,148.)

Arus.-Quarterly: 1 and 4, Azure, a .... between in chief three mullets Or, and in base a rose; 2 and 3, Or, in chief a lion rampant, in base an anchor erect, impaling, on a mound a tree.

Crest.-Out of a coronet two wings, and between them a mullet Or.

John Teschemaker, son of John Teschemaker of Essequibo, Esq., matric. from Exeter College, Oxford, 1813, aged 19. (Foster.)

282. "Diocese of Guiana, Cathedral Librari. B. Wyon sc 287 Regent stt." Arm. (F., 33,800.) Engraved about 1842.

Anms of the See.-Argent, a cross Azure, sumounted of a small long cross Or, on a chief Gules a lion passant guardant Or, in its dexter paw a pastoral staff bendwise resting on the sinister paw.

283. Wilitair Newtox Firebrace.

Born 1767 at Barbados. Of Demerara, Chief of the Legislative Council, mar. 1790 Mehetabel Christian Collier, and died 1821.

This plate in a book in the possession of his great-grandson IIr. C. W. Firebrace of Uckfield, Sussex.

The plate of Sir Basil Firebrace (first cousin to John F. of B'os), born 1653 , knighted 1687, created a Baronet 1698, mar. 1671 Eliz. Hough, and died 1724, is illustrated in the Franks Catalogue, vol. i., 368.

\section{\$กmaír.}

\section{ABBRETIATIONS.}

Livingston $=$ Sketch pedigrees of some of the Early Settlers in Jamaica, compiled from the Records of the Court of Chancery of the Island by Noël B. Livingston, 1909.

284. "ANdrew Arcedechie Gletering Hali." Arm. (F., 657.)

AnMs.-Quarterly : 1 and 4, Argent, three chevronels Sable; 2 and 3, Argent, on a chief embattled Sable three bezants [LEIGH]; impaling, 1 and 4, BECKFORD ; 2, Argent, three bars Gules, in chief as many lions' heads erased of the last [Love]; 3, Leigh. Crest.-An arm in armour, in the hand a surord.

MotTo.-DEUS PROTIDEBIT.

Eldest son of Chaloner A. by Cath., second dau. and co-heiress of John Leigh; mar. 1816 Anne Harriet, only dau. of Fra. Love Beckford, and died 1849, aged 69.

285. "J. H. Lawrence-Archer F. H. and G. S. Captatis lis Rotal Rifles" Arm. (F., 671.)

Arus.-Quarterly : I. Argent, a cross raguly Gules charged at the centre point with a saltire Or, on a chief Azure three arows palewise, points downurd. II. Quarterly: 1 and 4, Sable, a lion rampant; 2 and 3, Azure, three water bougets. III. Gules, a cross fretty Azure. IV. Argent, a cross raguly Gules, on a chief Azure three lions' heads cabossed Or.

CREsT.-Out of a mural crown a dragon's head.

MotTo.-Salutear Disponit DeUs.

Author of the well-known "M.I. of the British W.I." 4to, 1875.

286. "Joun Bailite, JaMaica." Arm. shield in a garter. (F., 1168.)

ARMs.-Azure, nine estoiles, three, three, two, and one.

Crest.-A boar's head couped. MotTo.-QUID cLariUs ASTRIs.

The will of Wm. Baillie of J. was proved in 1800 ( $8 \mathbf{I}$, Adderley). Sam. Crook Baillie of J. died 1790. ("G.M.," 476.) 
2S7. (B.rinax). Anonymous. Chip. arm. (F., 1440.)

Aras.-Argent, on a fess Gules, between three bears statant and muzzled Sable, a fleur-de-lis between two martlets close. CREST.-A stork among reeds close. "Barham." written in my copy.

Henry Barham, M.D., born 1692, mar. 1733 Eliz, widow of Col. John Foster, and died 1746. His M.I. with the above arms in Staines Church, co. Midd. The family of likchard Harris Barham of Kent may have used above plate.

2SS. "Jos". Foster Barmam Esq." Chip. arm. Noted by F.C. in E.L.J., xv., 149.

Anus.-Quarterly : 1 and 4, Argent, a chevron vert between three bugle horns stringed [FosTER]; 2 and 3, Argent, on a fess between three bears a fleur-de-lis between two martlets [BARHAM]. CREST.-A heron standing in rushes.

Fifth son of Col. John Foster, born 1729, assumed the name of Barham in 1750, as heir to his stepfather Henry Barham, M.D., mar. Istly, Dorothea Vaughan; 2ndly, Mary Pole, and died 1789.

289. "John Foster Barian" Printed label. (F., 1436.)

Of Trecoon, M.P., boru 1800, mar. 1834 Lady Kath. Grimstone, and died 1838.

290. "George Livius" Chip. arm. (E., 18,4t2, F.C.)

Two varieties. (W.E.B.)

ARMIs.-Vert, a chevron Gules between three pomegranates.

CREST.- $A$ (?) spike between two ostrich feathers.

Geo. Peter Livius, son of Peter Lewis Livius, Saxon Envoy at Lisbon, entered 1773 E.I.C.S., mar. 5 Sept. 1785 Mary Foster Barham of J., and died in 1816, aged 73.

291. "Georee Livius." Spade arm. (F.C.)

Arms and Crest as above, with the addition of Motto-confido.

292. "Barham John Livrus" Spade arm. (F.C.)

Arms and Crest as above. Eldest son of above, mal. his cousin Lucy Foster Barham. She was born 1791.

293. "JoHN BaRHaM Livius" Spade arm. (W.E.B.)

Rev. John Barham Livius, incumbent of Welborne, co. Norfolk, son of above Geo. Peter Livius.

294. "Eleanor Barritt." Arm, lozenge pendant from a ribbon. (F., 1619.)

ARMIs.-Azure, on a chevron Ermine, between three eagles' heads erased, two serpents.

295. "Harriet Barritt" (F., 1620.) The same plate with name altered.

Tho. Hercy Barritt, M. of C. 1775, mar. 1stly, Eleauor, dau. of Sam. Booth of Vere; 2ndly, in 1796, Ann Mellas, and died 1817. The above may have been his daus. by the first wife.

296. "NathaNiel BaylY" Chip. arm. (F., 1874.)

ARMs.-Or, on a fess engrailed Azure between three horses' heads erased of the second as many fleurs-de-lis. CREsT.-An antelope's head erased.

A. very wealthy planter, M.P. Abingdon 1759, and Westbury 1777 , mar. 1stly, in 1767 , the Hon. Eliz. Arthur Ingram; and 2ndly, in 1773, Sophia Magdalena Lamack who died 1788, aged 35. He died 1799. There was also a lawyer of Bath of the same names.

297. "ANNA BAYLY" Chip. arm. lozenge. (F.C.)

Arms of Bayly. Third dau. of above. 
330. (Cootre). Anonymous. (F., 6815.) Has in ink "Sir - Coote." The Arms have a crescent for a difference. Supporters: Two wolves, from their necks hanging a shield of Gules, a bugle horn. The badge and motto of the Order of the Bath.

Born 1762, General, K.B. 1801, Lieut.-Gov. of J. 1805-8, and died 1823. ("D.N.B.")

331. "Robert Corx, Jr, Yarmouth" Arm. (F., 6940.)

Arus.- Sable, on a chevron Or between three eagles' heads erased as many mullets Gules. On an inescutcheon: Erinine, on a chief Sable three crescents [Preston]. CRest. - Out of a coronet an eagle with wings expanded.

MOTTO.-VIRTUS SEMIPER TIRIDIS.

Alex. Aikman, Juur., of J., mar. Charlotte, second dau. of Robert Cory, attorney-at-law, of Great Yarmonth. (Archer, 244.)

332. "John Cussans" Chip. arm. (F., 7717.) By R. Hountaine, but not signed. (F.C.)

ArMs.-Or, an eagle displayed, in chief two barrulets Azure, a crescent for a difference; impaling, Argent, three wolves' heads couped Sable (MCQuEEN).

Crest.-An eagle displayed, charged with a bend, thereon three fleurs-de-lis.

Of Amity Hall, born 1742, mar. 1767 Euphine McQueen, and was dead 1789.

333. "Thomas Cussans Esq" ${ }^{\mathrm{R}}$ Arm. spade shield. (F., 7719.)

Arms of Cussans also with a crescent.

Crest charged with a bend sinister, thereon three annulets.

Elder brother of John, born 1739, was granted arms 1767.

John Edwin Cussans, the Historian of Herts, used a plate (F., 7718) with similar arms.

334. "George Cuthbert Michell, Bond St." Arm. spade shield. (F., 7745.) Not in Fincham.

ArMs.--Or, a serpent erect in pale debruised of a fess Gules.

CREsT. $-A$ mailed hand holding an arrow.

Mottoes.-Justé et recté above, and neC Minus Fortiter below.

Provost Marshal-Gen., died 1789, aged 42. (Ante, I., 142.)

335. "Stuart George Dallas" Arm. spade shield. (F., 7845.)

Arms, Crest and Motto of Dallas, elder brother of Chas. R. K. Dallas.

336. "Charles R. K. Dallas." Arm. oval shield. (F., 7842.)

ARMs.-Argent, a bend Azure between three mullets Gules.

Crest.-An in-crescent. Motto.-LUX venit a B aLTO.

The Rev. Chas. Robert King Dallas, Rector of Farncombe, mar. 1821 his cousin Julia Maria, and died 1860.

337. "R. Dallas" Festoon arm. (F., 7843.)

Arms, Crest aud Motto as F. 7842.

338. "Robert Dallas" Arm. spade shjeld. (F., 7844.)

Arms as F. 7842.

Robert Dallas, M.D., was the founder of this branch in J., where he died about 1769, leaving an eldest son Robert Charles. (Burke's "Landed Geutry" and "D.N.B.") Another R. Dallas, son of Alexr. Dallas of J., was B.A. Oxford 1790.

339. "Alexander R. C. Daulas" Arm. (F., 7841.)

Arms, Crest and Motto as F. 784:2, but the mullets Azure. 
Born 1791, died 1869, Rector of Wouston, co. Hants, eldest son of Rob. Cha. Dallas of Dallas Castle, J., and cousin of Chas. R. K. Dallas.

340. "COL DAlityG" Wreath and ribbon arm. (F., 7850.)

Aras.-Ermine, on a bend Gules three acorns, impaling: Or, a chevron Ermine between three lions passant [PrNNOCK].

CREST.-On a cannon a lion's head erased and chained.

Motтo.-AU BON DRoIT.

Col. John Dalling, Lieut.-Gov. of J. 17i1, created a Baronet 17S3, mar. 1stly, Eliz., elder dau. of Philip Pimnock and heiress of her uncle Col. Henry Darkins. She died s.p. 1768, aged 21. He mar. 2ndly, Louisa Lawford, and died 1798, aged 67. (Archer, 247, 278. Betham's "Baronetage," iv., App. 19.)

341. "Sir Windham Daluing Bart. Griffiths \& Weigalls, 3 St James's St." Arm. (F., 7851.) Not dated by Fincham.

Arms of Dalling, but the bend Sable.

CREST. - A cubit arm erect, couped, vested and cuffed, in the hand a sprig of oak.

Motto and Badge of Ulstel.

He suceeded as 2nd Bart. in $179 \mathrm{~S}$.

312. "JAMLS DaLY. JAMAICA" Arm. (IV.E.B.)

343. "Henrs Dawkins, Esq ${ }^{\mathrm{B}}$ " Chjp. arm. (F., 8174.)

Arus.-Gules, a lion passant guardant between two mullets in pale and as many flaunches Argent, ench charged with a lion rampant, a mullet for a difference.

344. "Henry Dawkins, EsQR" Chip. arm. (F., 8175.)

Anus.-Gules, a lion passant guardant Or between two roses in pale and as many flaunches of the second, each charged with a lion rampant Sable, impaling: Gules, on a cheoron Argent between three wolves' heads erased as mang trees uprooted [CoLTEAR].

Crest.-A bare dcxter arm, couped, in the hand a short battle-axe, and on the blade a rose.

Fourth son of Henry Dawkins of J., born 1728, mar. 1759 Lady Juliana Colyear, and died 1814 .

345. "Henry Dawkins EsQ ${ }^{\mathrm{B}} "$ Arm. (F., 8176.)

Arus.-Single coat and Crest of Dawkins, as in F. 8175.

346. "George Deharx EsQR" Arm. spade shield pendant from a ribbon. (F., 8367.)

Arsis.--Quarterly : 1 and 4, Azure, a bear evect, on a canton Or a cock; 2 and 3, Or, two bars Azure, in chief a lion passant guardant [Gregorr].

347. "George Dehany EsQ" A different plate in the same style. (F., 8368.) Ar3is.-Quarterly: 1 and 4, Demant ; 2 and 3, Gregory quartering Azure, six fleurs-de-lis, 3, 2, and 1, a chief indented Or [THURGAR]. The last coat on a shield of pretence is on Dr. Mathew Gregory's monument. (Archer, 46.)

A barrister, son of Geo. Dehany by Mary, second dau. and coheir of Mathew Gregory, M.D.; born 1760, mar. 1786 Sarah Jones, and died 1807.

349. " WV. K. Demany Esq $Q^{\mathbb{R}}$ " The above plate with altered inscription. (F., 8369.)

His wife Eliz. Favell, dau. of Vice-Admiral M. H. Scott, died 1838 in Belgrave Square. 
349. "JAMres Buller EAST" Arm. (F., 9498.)

Anus. - Azure, a chevron Argent between three horses' heads erasea; impaling, Gules, a cross engrailed Argent, in the first quarter a lozenge of the second [Letge]. Crest.-A horse. Motto.-AQUo PedE PRopera.

350. "Sir James Buller East, Bart." Arm. (F., 9499.)

ArMs.-Quarterly: 1 and 4, Esst, the field Sable; 2 and 3, Per pale Gules and Azure, a wolf salient Or [HANEET]; impaling LEIGH.

Born 1789, B.A. Oxford 1810, mar. 1822 Caroline Eliza, dau. of Jas. Henry Leigh of Stoneleigh Abbey, co. Warwick, succeeded as 2nd Bart. 1847, and died 1878.

351. "Bryan Edwards Esq Greenwich ParK, JalraIca. Ashby sculp. Russel Court London" Chip. arm. (F., 9596; Allen, 247.)

Engraved about 1760. (Fincham.)

A RMrs.-Per bend sinister Ermine and Ermines, a lion rampant Or.

Motio.--Nosce TE IPstr.

352. "Bryax Enwards" Crest. (F., 9597.)

Crest.-A lion's head erased.

Born 1743, M.P., Historian and Planter, mar. 1774 Martha Phipps, and died 1800. ("D.N.B.")

353. "B. Edwards J ${ }^{\mathrm{B}}$ " Arm. Printed on rose paper. (F., 9595.)

Arms and Crest of Edwards. Motro.-Nolt inRITaRe Leonem.

Son of Zacchary Bayley Edwards, and nephew of Bryan, died 1835, aged 29.

"Katherine Countess of Effinghanr" See under "Beckford." 9725.)

354. "Roger Hope Euletson Esq Trin. Coll. Cair." Jac. arm. (F.,

Anars.-Quarterly: 1 and 4, Per pale Gules and Vert, an eagle displayed; 2 and 3. Argent, a chevron between three hurts.

MIotTo. - JAI BONNE ESPERANCE.

Lieut.-Governor of J. 1766, born 1727, died 1775. (Ante, I., 81.) For his daughter see F. 22,358, Amna Petronilla Ord. For his widow see F. 4185 (Brydges), James, Duke of Chandos, 1777. (F.C.)

355. "George Eulis EsQ" Chip. arm.

ARurs.-Or, on a cross Sable five crescents Argent.

Crest.-A goat's head erased Argent. (Illustrated in E.L.o., xvii., 15S.)

Geo. Ellis, Chief Justice of J., died 1740; Geo. Ellis, junr., his eldest son, born 172S, mar. 1746 susanna Charlotte Long, and died 1753, having had issue a son Geo., born 1753, died 1815. The plate probably belonged to the second Geo.

356. "JoHr Elis EsQ ${ }^{\mathrm{R}}$ Neele, sculpt." Arı. spade shield in a beaded oval. (F., 9787.) Engraved about 1790 (Fincham).

Ariss.-Eutis impaling: Gules, on a chevron Argent between three leys as many fleurs-de-lis [PaRKer]. Crest of Ellis. Motro.-PLUs UNA LUNA.

No. 9798 is the same plate without inscription.

Boru 1757, of Hurlingham, mar. 1795 Antoinette Parker, and died 1832.

357. "Altixander ERskine." Spade arm. Before 1833.

Anus.-Quarterly : 1 and 4, Argent, a pale Sable; 2 and 3, Gules, a suord erect in pale Argent, hilt and pommel Or. [DUN].

CREsT.-A gryphon's head erased, in its mouth a sword in bend, all ppr.

Motro.-IN INOMINo CONFIDo.

Of Lima and Dun Pen, parish of St. James. (E. E. West.) 
358. "Alexir Ersine" Arm. Stupporters.

Arms, Crest and Motto as above, with the addition of the Supporters: Two gryphons Gules, winged and armed Or.

Matriculation in Lyon's Office :26 July 1833, as heir male of the ancient baronial family of Erskine of Dun. Mrr. E. E. West, great-graudson of the above, has the original copper plate.

359. "Jorn Peter FeanoN" Crest in a garter. (F., 10,289.)

Crest.-An eagle's head out of a coronet. Motro.-TIM Unum.

Tho. Peters Fearon of J. mar. 1782 Anna Maria Boyfield. Tho. Fearon was Chief Justice in 1765.

360. "Gilbert Ford. Lincolns Inx" Chip. arm. (F., 10,950; F.C.)

A Rus - Azure, three lions rampant crowned, a martlet for a difference.

Crest.-A demi-lion rampant crowned. Motro.-Sibl ex Aurcis.

Of a Bristol fimily, Attorney-Gereral of J., and died 1767.

361. "Grubert Fond EsQ Lrycolns Ixy" Chip. arn. A different plate from the last. The same coat and crest, but a crescent for a difference.

MótTo.- videmus asSEQUAMUR. In earlier state of this plate has for MIotto TIDEMUS ASSEQUIMLR. (F.C.)

362. "Ixgmàn Foster" Chip. arm. (H., 11,065.)

ArMs.-Quarterly: Perfess indented Argent and Sable, in the first and fourth quarters a bugle horn of the second. CREsT.-A stag's head erased.

Mot'To.-INTIDIAA. TIRTUTE VINCAM.

See cute, II., 350, where he is styled "Ingram" in a deed of 1777 . In the will of John Smith of London and Antigua of 1775 he is styled Ingham Foster of Clement's Lane, ironmonger.

363. "Tromas Foster" The above plate with altered inscription. (F., 11,079.)

364. "CALEB Foyster" Chip. arm. literary. Illustrated in E.L.J., xvi., 148. (F.C.)

Anus.-Sable, a stag at gaze between three plates, each charged with a heror's head erased, within a bordure compony Argent and Gules; impaling, Checky Argent and Gules, a lion rampant.

Crest.-A stag's head erect, couped, collared, and chained.

MotTo. - Nascentes MoriniUR.

Died 1777, aged 69. (Archer, 126.) There was a grant of arms, but not of the above, in $178 \pm$ to Sam. Foyster of St. Pancras.

365. "Willian Fowle. Co. Wilts." Seal arm. Engraved by Beckwith for Burke's "Heraldic Illustrations." (F., 11,114.)

Arms.-Quarterly: 1 and 4, Gules, a lion passant guardant between three roses Or, an annulet for a difierence; 2 and 3, Azure, a stag's head cabossed Argent [LEGGE].

Crests.-1, Out of a coronet a dexter arm in armour embowed, in the hand a battle-axe bendwise; 2, Out of a coronet a plume of five ostrich feathers.

MotTo.-BOUTEZ EN AVANT.

William Fowle of Wiltshire plantation died 1796. His nephew Tho. F. mar. Bridget, dau. and coh. of Rich. Legge, and had a son William, who used the above plate.

$$
\text { 366. "JACOB Franco, } \text { EsQ }^{\mathrm{R}} \text { " Chip. arm. (F., 11,204.) }
$$

* Mr. J. Salomons of 118 Sutherland Arenue, a collector of Jerrish plates, and Mr. ColyerFergusson of Ighth:in Mote have helped to elucidate the Franco pedigree and identify the above plates. 
ARMs.-In a landscape field a fountain, thereout issuing a palm tree and water spouting, a crescent charged with a crescent for a difference as second son of the second house. CREST.-A dexter arm habited, couped, in the hand a palm branch.

MotTo.-sub PaCe copia.

367. "Ј ЈСов Fraxco, EsQRE" Chip. arm. (F., 11,205.)

Arms of $F$. with $F$. on an inescutcheon, a crescent charged with a label for a difference as eldest son of the second house. Both plates probably belonged to the same man. This coat was granted in 1760 to Jacob, who was second son of Moses F. of Leghorn.

Jacob and his elder brother Abraham were co-partners, and built themselves adjoining houses in Fenchurch Street. The former mar. his niece Simha, and died in 1777 . The marks of cadency are puzzling, as they differ.

368. "Raphael Franco, EsQ" ${ }^{\mathrm{B}}$ " F. 11,204 with inscription altered. (F., 11,207.)

He was also a merchant of Fenchurch Street, and second son of Jacob and Simha, mar. 1761 Leah D'Aguilar, and died 1781. Three of his sons settled in J., and one of them, Abraham, was father of Sir Ralph Lopes, 2nd Bart.

369. "Moses Franco, EsQ ${ }^{\mathrm{B}}$ " Chip. arm. (F., 11,206.)

Arms as in F. 11,204, but a crescent charged with a label for a difference.

He may have been the eldest son of Jacob and Simha, who died v.p. in 1774. Jacob also had a cousin Moses.

370. "E. Franco" Festoon. (J.M.)

Probably Ephraim Franco of London, who was a son of Raphael and Leah, and ex'or 1808 to the will of his brother Joseph of J.

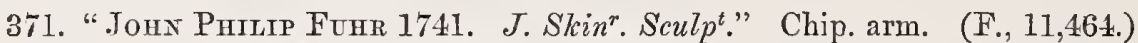

AnMs.-FuHr (the field Argent) impaling, Or, two wings conjoined in lure.

Crest.-A demi-bear couped.

372. "EDwdRD FuHR" Wreath and ribbon arm. (F., 11,463.)

Anus.-Or, on a chevron Sable between in chief three eagles displayed and in base a palm tree on a mound, five mullets of the field.

CREst. - A demi-bear couped reguardant.

MotTo.-CREscit sub PoNdere palma.

Of London, merchant, in 1793 (ante, II., 331). The will of Chas. Fuhr of J. was proved in 1801 .

373. "W. GALE" Chip. arm. (F., 11,585.)

ARMrs.-Azure, on a fess between three saltires Or as many lions' heads erased, collared Azure.

CREST.-A unicorn's head erased, collared, charged on the collar with three saltives.

F. 11,586 is another state of the same plate, and has three griffins' heads on the fess in place of the lions' heads. (F.C.)

William Gale, M. for Hanover 1754, mar. Eliz. Morant, who died 1759, aged 31 .

374. "James Galloway. Warwick sc. 145 Strand" Crest. (F., 11,597.) Engraved about 1S10. (Fincham.)

Crest.-A grenade surmounted by a cross Gules. Motro.-Altion.

He died 1833, aged 75. M.I. with arms in Archer, 326.

375. "Caleb John Garbraxd" Chip. arm. (F., 11,633.) 
ARMS.-Argent, a battle-axe in bend sinister surmounted of a lance in bend dexter, and in chief a dart barwise. MotTo.-DUM SPIRo speno.

John Garbland of Jamaica died in 1722, aged 28. Joshua Garbrand had a grant of : ilms 1768 .

376. "Alan Gardner" Festoon alm. (F.C. in E.L.J., xvii., 159.)

ArMs.--Gardner, and on an iuescutcheon GaLE.

Admiral and C.-in-C. at J. 1786-S9, born 1742, mar. 1769 Susanuah Hyde Gale, only dau. and heir of Fra. Gale of J., created Baron 1800, and died 1809. (D.N.B. and ante, p. 16.)

377. (Baroll) "Gardner" Arm. (F., 11,656.)

A Rus.-Quarterly : 1 and 4, Argent, on a chevron Gules, between three griffins' heads erased Azure, an anchor between two lions passant combattant; 2, Argent, a chevron Gules between three leopards' faces cabossed Sable; 3, Gules, three cinquefoils Aigent [Farrington]. A Baron's coronet, Supporters and Motto.

378. "JAMI GoRdon EsQ ${ }^{\mathrm{R}}$ (J. Gretton fecit)" Chip. arm. (F., 12,278.) Engrared about 1760. (Fincham.)

Anus.-Azure, on a fess checky Argent and Azure, between three boars' heads couped, a lion passant guardant, impaling, Gules, on a bend between two lions rampant Gules a rose [HeRRING].

Crestr.-A stag's head couped. MotTo.-NON FRAUde SED LAUdE.

There was a James Gordon of Kingston, J., merchant, circa 1770.

379. "MIRs Gordon" Chip. arm. lozenge. (F., 12,287.)

ArMs.- Azure, on a fess checky Argent and Azure, between three boars' heads erased, a lion passant, impaling: On a bend Argent a rose supported by two lions passant [HERRING]. MOTTO.- NON FRAUDE SED LAUDE.

Evidently the widow of the above James.

380. "JoHn Gordon. Cook sc." Arm. spade shield. (F., 12,281.) Engraved about 1800. (Fincham.)

Arus.-Azure, three boars' heads in fess, impaling, Gules, on a bend Argent a cinquefoil between two lions passant [HERRING].

Crest.-A demi-savage affrontée, around the loins a wrenth of leaves, in the dexter hand a club upon his shoulder.

Of Bristol, boru 1758, mar. 1787 Cath., eldest dau. of Julines Hering of J., and died 1839. He was second cousin of John Gordon of Wincombe Park, Wilts. The family was from Aucheudolly, co. Kirkcudbright. (Ante, II., 12.)

381. "JoHn Gordon" (F., 12,282.) The same design as 12,281, but without engraver's name.

CREST.- Two arms couped, the hands clasped fessways, surmounted of a human heart. MотTO.-ANimo NON ASTUtia.

382. "WrLLIAM GoRdON" (F., 12,299.)

Like F. 12,282, but impaling: Sable, on a bend Or three gilliflowers within a bordure Argent $[\mathrm{W} \mathrm{ADE}]$.

383. "JoHN GORDON" Arm.

ARMs.-Azure, three boars' heads couped.

CREST. - A demi-man couped, holding in dexter hand a club.

Of Wincombe Park, co. Wilts, born 1774, mar. 1stly, in 1792, Sybella Partridge, and 2ndly, in 1825, Maria, dau. of Nath. Brassey of Lombard Street, and widow of Rich. Oliver of Bath and Antigua, and died 1833. He owned Glasgow plantation in St. James, J. 
384. "Matrhew Gregony. Ex Rde Christi." Jac. arm. (F., 12,764.)

Anrs.-Or, two bar's Azure, in chief a lion passant of the second.

CREST.-A demi-witd boar conped. collared Or.

Son of John Gregory, President of J. 1755, matric. from Christ Church, Oxford, 1728-9, aged 15, B.A. 1732 .

(F.C.)

385. "Thos. LxNch Goleborn Ese" Spade shield wreath and ribbon arm. A RMrs. - Argent, a cross flory Gules between four martlets.

Crest.-An anchor in bend sinister cabled. Not in Burke's "Armory."

Of J. and Trin. Coll., Cambridge, mar. 1792 Cath., first dau. of Sir Joseph Mawbey, 1st Bart.

386. "Henrt GodlBurN EsqR" Arm. (F., 12,367.)

Arass.-Single coat and Crest.

Eldest son of Munbee Goulburn of J., born 1784, D.C.L. 1834, M.P., Chancellor of the Exchequer 1828, 1830, and 1841-6, Home Sec. 1834-5, mar. 1811 Jane, third dau. of the 4th Lord Rokeby. and died 1856. (Foster.)

387. "Edward Goulbern, Esq" Arm. (F., 12,364.)

AnMs.-Argent, a cross Gutes between four falcons; impaling, Argent, a chevron Gules between two mullets in chief and a crescent in base Argent. A crescent for a difference. CREsT. - A falcon erect, in its mouth a sprig.

Second son of Mumbee Goulburm, barrister of the Midale Temple 1815, Serjeant-at-law 1829, D.C.L. 1845, M.P., mar. 1815 Harriette, dau. of Philip Nath. De Visme, and died 1865. (Foster.)

388. "Edward Merrick Gouldurn." Arm. (F., 12,365.)

Arus. - Single coat with a label on the erescent for a difference. Crest.

389. "Frederick Anderlechi Godliurn." Arm. (F., 12,366.)

Anus.- Single coat with a crescent on the crescent for a difference. Crest.

390. "James Grosett Esq ${ }^{\mathrm{B}}$ of Lisbon Merch" alias J. Grosett MuinHEAD OF BREDISHOLM EsQ ${ }^{R}$ Chip. arm., two shields accolé. (F., 12,957.)

ArMs.- No. 1 shield: Quarterly, 1 and 4, Azure, three mullets in fess, in chief an acorn, in base three bezants barwise, a mullet for difference; 2 and. 3, Argent, on a bend Azure three acorns Or [MuIRHEaD]. No. 2 shield: Gules, five women kneeling, each holding a pole [DE MIIRANDA].

Crest. - A cubit arm couped, in the hand a sword bendwise.

Mottofs.- - buve: pro Patria auxilio dei. Below: CAHIND Las sustentey.

He assumed the additional surname and arms of Nivirhead in 1753, mar. Douna Leonora de Miranda of the House of Cordova, Spain. Probably of the same family as John Rock Grosett, secoud son of Schaw G. of J., born 1784, M.P. 1820, M. of C., died 1866.

391. "JAMEs HaLL" Chip. arm. (F., 13,304, and Alleu, 340. Illustrated in E.L.J., xvii., 158.) (F.C.)

Anus. - Argent, a chevron between three talbots' heads erased Sable.

CREST. - A talbot's head erased Argent pellettée Or (sic).

Born 1698 at Kingston, J., mar. Eliz., sister of Col. John Cossles, and died 1742 , but the plate is of about 1750 .

392. "TVildiam James Hali" Chip. arm. (F., 13,347.)

Arms as above. Crest.-Sable, pellettée Argent.

Eldest son of James Hall, died s.p. 
393. "Cosslet HaLx" Chip. arm. (F., 13,292. Illustrated in E.L.J., xvii., 159.) The same design as $\mathrm{F}$. 13,347.

Arms of Hall with the addition of a mullet in centre of the chevron, and in centre chief point a crescent. A later plate has a star of six points wavy Or instead of the mullet, and the Crest is bezantée.

Crest.-A talbot's head Sable plattée. Motto.-Renember and folrget not.

Second son of James Hall.

394. "Wildiam James Halt" Arm. (F., 13,348.)

Arms of Hall, but the chevron engrailed.

MoTTO.-MEMENTO ET NE OBLIVISCE.

Son of Cossley Hall, born 1764, Auditor-Gen. of J., and died, bach., 1827.

395. "Joseph TAIL, EsQR" Jac. arm. shield on a mantle, Hall impaling Calvert. (F., 13,322.) The same coat as F. 13,347.

396. "Jasper H.tL" Alm. (F., 13,308.) Engraved about 1840. (F.C.)

ARMs.-Erminois, a chevron Gules between three demi-lions rampant couped, on a chief embattled of the second as many roses.

Jasper Hall the Elder was Receiver-Gen. 1760, Speaker, and died 1778, leaving a son Jasper, who died 1796. The latter's only dau. Jane mar. Admiral Sir Edw. Codrington, G.C.B., and died 1837.

397. "HaMpson" Arm. (F., 13,577.)

Ariss.-Argent, three hemporakes Sulte.

CREST.-Out of a mural crown a greyhound's head collared.

MOT'TO.-NUNC AUT NUNQUAM.

Sir Geo. Fra. Hampson, 6th Bart. of J., mar. 1759 Mary, eldest dau. of Tho. Pinnock of .J., and died 1774. The above plate was used by a descendant.

398. "Thouras Duffus Hardy, F.S.A." Arm. (F., 13,726.)

ARMs.-Sable, on a chevron, between three escallops Or, as many dragons' heads of the first.

CREsT. - A dexter arm embowed in armour couped, in the hand a dragon's head erased.

Born 1804 at Port Royal, Knighted, died 1878. (W.E.B.) There are several more of his plates.

399. "Richard Havghton" Arm. (F.M.)

Richard Haughton of J. died 1740, aged 49, leaving a son Richard. (Livingston, 46.)

400. "James Har." Arm. spade shield with palm wreaths.

ARurs.-Argent, three escutcheons Gules.

Crest.-A falcon with wings expanded. Motro.-SERva JuGuM.

Inserted in a Horace of 1778 belonging to Miss G. C. Hay of Fort William and Roaring River, Jamaica, shewn me 4 Dec. 1912. Her grandfather Capt. John Baker Hay, R.N., died in 1823, aged 62. The arms are those of the Earls of Kinnoull. Jas. Hay, a Judge of J., who died 1735, bore on a cross five escallops. (See ante, I., 323.)

401. "JaMes W, Hay." Arm. spade shield with palm wreaths.

Arms and Motto as above.

Crest.-A demi-Scotsman couped at the knees, vested in a plaid, and capped, bearing on his shoulder an ox-yoke.

Inserted in a life of Sir J. Reynolds of 1801, belonging to Miss G. C. Hay. He was of the Sec. of State's Office in 1799. (Ante, I., 188.) 
402. "Richard Heath" Festoon arm. (F.M.)

? Of Spring Mount plantation.

403. "Samuet Heming de sancta Anna Parochin̂ in Jamajcâ Araitgr" Chip arm.

Motto.-AUt NUnQdaM tentes adt PERfice. (Allen, 372.)

404. "HEM1NG" Chip. arm. (F.C.)

AnMs.-Or, on a chevron Sable, between three lions' heads erased of the second, three pheons of the first. CnEsT.-On a chapean a lion sejant Ermine.

405. "Hentrg" Spade shield wreath arm. (F.C.)

Arms and Crest as above. Motto.-AUt nunQuAM tentes aUt perfice.

Not in Burke's "Armory." Rich. Heming of J. named in 1672. (Ante, II., 147.) Samuel Heming of J. died 1720 (85, Bolton), leaving an elder son Richard, d. 1755 (283, Paul), and a younger son Sam., who died 1751 (301, Webster), who both left issue.

406. "Alexander Henderson. Lizars sculp" Arm. shield on a mantle. (F., 14,440.) Not in Fincham.

Arms. - Gules, three piles issuant from the sinister Argent, on a chief of the second a crescent between two ermine spots.

CREsT.- $A$ cubit arm erect, in the hand a star, surmounted by a crescent.

MotTo. - sola VIRTUS noBilitat.

Perhaps a descendant of the Attorney-Gen. of J. of above name, who died 1732 , aged 36.

407. "Janes Modyford Herwood, Maristow Deron" Chip. arm. (F., 14,666.)

Arus.-Quarterly : 1 and 4, Argent, three torteaux between two bendlets Gules, all within a bordure of the last [HEYwoon]; 2, Ermine, on a bend Azure a mullet pierced Argent between two garbs Or. [MODYFORD]; 3, Argent, two pales engrailed Gules, over all on a bend Azure three griffins' heads erased [SuANNiNG]. On an inescutcheon Sable a chevron Ermine between three otters passant Argent [HARTopp]. CREst.-A falcon on the stump of a tree with wings displayed.

Of Heywood Hall plantation, which he sold. Sheriff of Devonshire 1759, mar. Cath., dau. and coh. of General Cheverton Hartopp, and died 1798, s.p.m.

408. "George Hibbert" Festoon arm. (F., 14,673.)

Ariss.-Ermine, on a bend Sable theee crescents.

Crest.-A lion passant. Motro.-medio tutus.

Agent for J., and died 1837, aged 80, cousin of Thos.

409. "Arma Johannis Nembhard Hibbert, Chalfont House." Seal arm. (F., 14,674.)

Arurs.-Quarterly : 1 and 4, HibBert ; 2, Argent, a bend engrailed Sable, cotised Gules [TeTLOW]; 3, Vert, a bend Or between two garbs [SCHOLEx], impaling, Quarterly: 1 and 4, Per pale Argent and Sable, a cherron counterchanged, on a canton Azure a harp [ALExANDER]; 2 and 3, Ermine, a chief between three cinquefoils Gules. Motro.-Fidem RectumQde colendo.

He mar. 1833 Jane Anne, dau. of Sir Rob. Alexander, 2nd Bart.

410. "Thomas Hibbert" Arm. (F., 14,675.)

Arms.-Hibbert, impaling: Gules, a bend cotised Argent between six crossescrosslet Or [MANSFIELD].

CREst.-An arm erect couped, vested Azure, cuffed Ermine, in the hand a crescent of the last.

Born 1761, of Agualta Vale 1780, mar. 1792 the dau. of J. Rushton Mansfield of Thrapstone, co. Northants, and died 1807. 
411. "Washixgton HibBert es $\Omega^{R} "$ Arm. (F., 14,676.)

A l'ms and Crest of Hibbert. Plate by Pugin.

Second son of Tho. Hibbert of Agualta Vale, J., was of Bilton Grange, co. Warw., mar. Julia, dan. of Sir Henrr Tichborne, 7th Bart., and widow of Lieut.-Col. the Hon. Chas. Tho. Talbot, and died 1875.

412. "Thomas HibBert"* Arm. spade shield and wreath. ? From a new plate or a recent impression from an old one.

Anus.-Ermine, on a bend Sable three crescents Argent. A label of three points for a difference.

CREST.-A cubit arm couped erect, vested, cuffed Ermine, in the hand a crescent.

Son of Robert Hibbert of Stockfield Hall, co. Lanc., bap. 1745. Sometime of J. and later of Chalfont Park, co. Bucks, mar. Sophia Boldero, and died s.p. 1819.

413. "Robert Hibbert." Arm. 1816. (Not in F.)

Arus.-Hinвегт, impaling: Azure, a fess Or between three fleurs-de-lis [Leicester]. A crescent for a difference. Crest of Hibbert.

Second son of Robert Hibbert of Jamaica and Birtles House, Cheshire, by Letitia Hamilton Nembhard his wife, and mar. Istly, in 1816, Letitia Kath. Leicester, only dau. of Henry A. Leicester', younger brother of the 1st Baron de Tabley. She died in 1817, aged 18.

414. "Charles R. C. Hibber't."* Arm.

Arus and Crest of Hibbert. MiotTo.-FIDEM RECTUM-QUE Colendo.

Charles Robert Calvert Hibbert, eldest son of Leicester Hibbert of Crofton Grange, Kent, born 1852, mar. 1896 his cousin Margaret Dora, third dau. of Col. Hugh Robert Hibbert of Birtles Hall, Cheshire.

415. "Veronica Hibbert Ashby Saint Ledgers Northamptonshire" Arm. pict.

Arms of Hibbert in a lozenge.

IIOTTO.-GOD BIDS YOU TRY, HE DOES NOT SAY SUCCEED.

416. Robert Fiennes Hibbert of Bucknell in the Codnty of Oxon.* Jac. arm. (modern).

Aruss.-Quarterly: 1 and 4, HibBert; 2 and 3, Argent, a cross between four roses Gules [Troturas]. On an inescutcheon: Quarterly, 1 and 4, Gules, a chevron Argent (1ightly Or) between two fleurs-de-lis in chief and an eagle displayed in base [READE] ; 2, Ermine, a chevron between three roses Gules; 3, Per pale Argent and Sable, a chevron and in base a crescent counterchanged, on a canton Azure a harp [ALEXANDER]. Crest of Hibbert over helmet.

Motro.-FIDEM RECTUMQUE COLENDO.

Eldest son of Fred. Drummond Hibbert of Bucknell by Hester Louisa, second dau. and coh. of Fiennes Trotman of Syston Court, b m 1860, mar. 1887 Florence Jane, only child of Philip Villiers Reade of Wood Park, co. Galway, by Caroline Charlotte, dau. of Rob. Du Pré Alexander.

417. "Ex Libris Munden. H J F. BADELEF. 1903 "* Arm. Jac. mantling.

AnMs.-Quarterly : 1 and 4, Ermine, on a bend embattled and counter-embattled between two crosses-crosslet fitchy four crescents Argent [HIBвERT]; 2 and 3, Per bend Argent and Azure semée of fleurs-de-lis a lion rampant counterchanged, debruised of a bend engrailed Gules [HoLLaND]; impaling, Per pale Argent and Sable a chevron counterchanged, on a canton Sable two barrulets Or.

Crests.-1, A cubit arm erect couped, cuffed Ermine, in the hand a crescent [HIBвERT]; 2, Out of a mural crown a demi-lion rampant guardant, collared with a band engrailed Argent and Azure, and above the dexter paw a fleur-de-lis [HOLLAND].

* The above six plates were forwarded by Miss M. Nembhard. 
Motto above: Respice aspice PRospice. Below : ANIMICM IPSE Parabo.

The Hon. Arthur Henry Holland-Hibbert of Munden, co. Herts, second son of Henry, 1st Lord Knutsford, by his first wife Eliz. Margaret, dau. of Nath. Hibbert of Munden, born 1855, mar. 1884 Ellen, first dau. of Sir Wilfrid Lawson, 2nd Bart. Assumed the name of Hibbert in 1876.

418. "George Hinde," Chip. arm. (F., 14,810.)

Anss.-Gutes, a chevron Or between three hinds.

CREST.-A cockatrice out of a coronet.

He mar. 2ndly Poyntz, and died 1756. "Rob" Hinde Esq ", Chip. (F.C.), has the same arms. "See Cussans' "Herts."

419. "Thomas Hodges Esq" Jac. arm. shield within paim branches. (F., 14,936.)

Arus.-Or, three crescents Sable, on a canton of the second a coronet.

CREsT. - Out of a coronet a crescent Sable.

Eldest son and heir of Capt. John Hodges of .J., and of St. James' Place 1769.

420. (Hodges). Anonymous. Chip. arm. (F., 14,942, and F.C.)

ARMs.-Or, three erescents, on a canton sinister Sable a coronet; impaling, Argent, a fret Gules [BLAKE].

Crest.-Out of a coronet an heraldic antelope's head.

Thos. Hodges, eldest son and heir of Capt. John Hodges of J., was of St. James' Place, London, in 1769 ; mar. Frances Barbara, sister of Sir Patrick Blake, 1st Bart., of St. Kitts. Both named in latter's will of 1784 .

John Hodges of Maxfield, J., mar. 1stly Anne Blake. (Archer, 324, 328.)

421. "His Excellenct Robert Hunter Esq Captain General \& Chief Governour of Jamaica. A Johnston sculp." Jac. arm. (F., 15,778; Allen, 399.) Engraved about 1740. (Fincham.) Illustrated in E.L.J., viii., 141, 164.

AnMs. - Vert, three greyhounds courant Argent, on a chief of the second as many bugle horns stringed. CREsT.-A greyhound's head erect erased.

A later state has a motto-AUXILIUM AB ALTE-added around the shield. (F.C.)

Governor 1729, mar. Eliz., only dau. and heiress of Sir Tho. Orby of Croyland Manor, Bart., and widow of Lord John Hay, and died 1734, leaving an only son. (Livingston, 134.)

422. "Tho ${ }^{\mathrm{s}}$, Orby Hunter EsQR", Chip. arm. (F., 15,782.)

Arms and Crest as above.

Great-grandson and last male descendant of the Governor. Richard Heming of $\mathrm{J}$. in his will, dated 1753 , calls him bis brother-in-law. He was M.P. for Winchelsea, and died in 1769.

423. "John Hunter of Jamaica" Arm.

Arms as above, impaling, Quarterly, 1 and 4, Or, a lion rampant; 2 and 3, Sable, three horses' heads couped. Crest.-A greyhound's head couped.

(Plate sent by a dealer.)

424. "JoHn Hrde" Arm. spade shield pendent from a ribbon. (F., 15,894.)

ArMs.-Gules, a saltire between four bezants, a chief Ermine.

425. "JoHN HIDE EsQR" Chip. arm. (F, 15,896.)

ArMs.-Gules, two chevronels Argent.

Crest.-A tilting spear-point with pennon.

Son of John Hyde of Marlborough, succeeded 1750. Later of Hyde End, co. Berks, and died 1819 , aged 72. 
426. "P. S. Hrnes" Arm. spade shield. (F., 15,907.)

Arrs. - Gules, on a mount Vert a tower supported by two lions combatant.

CREST.-Out of a coronet a spear-point with pennon.

Motto.-TURRis fortis Min Deus. (See F., 8377, ante.)

427. "Jines IvaLIS" Arm., 1805 water-mark in paper. (F., 16,022.)

ARIS.-Azure, a lion rampant between two bezants in fess, on a chief Argent three mullets Azure. CREST.-A demi-lion rampant, in the mouth a mullet Argent.

Mo'To.-ReCte Facrendo securus.

A will of James Inglis of J. was proved in 1789 .

42S. "M MJOR IRTiNg" Spade and mantle arm. (F.C.)

AnMs.-Argent, three holly branches of as many leaves Vert.

CREsT.-Three arrows tied around with a ribbon.

MOTTO.-SUB SOLE SUB UMBRA virens.

- Of the 1 W.I. Reg., Lieut.-Col. at his death at Bath in 1808, after active service of 33 years.

429. "HaUghton JaMes EsQR." Chip. arm. (F., 16,263.)

Anus.-Quarterly: 1 and 4, Azuve, on a chevron between three lions passant guasdant Or, as many mullets of six points Sable [JAMEs] ; 2, Sable, a man Argent holding in the dexter hand a club [? EuLEx]; 3, Argent, three bars Sable [Hadghton]. Crest.-A stag statant. (Illustrated ante, II., 1.)

Born 1738 and died 1813.

430. "Hugo James EsQR. Middut Temple" Crest. (F., 16,265.)

CREST.-A bull's head couped, in its mouth a lighted torch.

MotTo.-ESSE ET VIDERI.

Attorney-Gen. of J., born 1750.

431. "William Rhodes James" Arm. (F., 16,290.)

ARMs.-Azure, on a chevron Or, between three lions passant, as many escallops.

Crestr.-A demi-lion couped, in its paws an escallop.

There were four generations in J. with these names. The third died 1795 , aged 40.

432. "H. N. Jarietw" Arm. (F., 16,324.)

AnMs.-Azure, a lion rampant guttée and crowned.

Crest.-A lion's head erased guttée, collared and crowned.

Herbert Newton Jarrett, Jun., grandson of H. N. J. of Orange Valley, who died 1790, was of Grove Place, co. Hants, mar. 1801 Anne Stephens, and died 1811. His uncle of the same names was of Norfolk in 1801.

433. "Johr Johnston of JAMAICA" Arm.

Arus.-Argent, a saltire Sable, on a chief Gules three woolpacks.

CREST.-A dexter arm in armour, in the hand a dagger.

MotTo.-NUNQUAM NON PARATUS.

(Plate sent me by a dealer.)

434. "JoHN JoHNSTON OF JAMAICA."

Arms of J.impaling: On a bend Azure between two unicoms' heads erased three lozenges.

(Plate sent me by a dealer.)

435. “Kеiтli JopP" Arm. (F., 16,737.)

Anus.-Gules, a garb, on a chief' Argent a ship in full sail.

Crest.-On a garb lying fessways a cock crowing. MотTo.-8rc Donec. 
Of Aberdeen and Keith Hall, J. Eleanor his widow died 1859, aged 82. M.I. in Christ Church, Cheltenham. A portrait of Mrs. Keith Jopp by Hoppner fetched $£ 2440$ at the sale of the Fischoff collection in Paris in June 1913. There was a family of Jopp of Winkton, Christchurch, co. Hants.

4.36. "JAMES JoPP EsQ" Arm. (F., 16,738.)

Ariss.- J., impaling Or, a fess wavy Gules between six cinquefoils.

Crest and Motto as above.

437. "Charles Jopp" Arm. (F., 16,736.)

The same coat as F. 16,737.

438. "RoвERT KeITH EsQ ${ }^{R}$ " Chip. arm. (F., 16,873.)

Arms.-Quarterly: 1 and 4, Argent, on a chief embattled Gules three palets Or, a bordure crenellée of the second [KЕाтH]; 2 and 3, Or, a fetterlock Sable, on a chief Azure three stars [MURRAY].

Crest.-An Ermine. Motto.-Ex Candone Decus.

He was of Craig, Ambassador at Vienna and St. Petersburg and father of Sir Rob. Murray Keith of Murraysfield, K.B. (whose plate is F. 16,874), and of Sir Basil Keith, Governor of .J. (Burke's "A rmory"). The last-named died 1777, and his arms as above quartered are on his tablet in J. (Archer, 52.) 4031.)

439. (Browne, Marquess of Sligo) "Westport House." Arm. (F.,

ArMs.-Quarterly : 1, B. as in F. $4060 ; 2$, Azure, a tower supported by two lions combatant [K ELII]; 3, Or, a fess Sable between three wolves heads erased; 4, Argent, a chevron Sable between three badgers.

Supporters, Crest and Motto.-F. 4050, 1, 2 have the same arms of B.

Howe Peter, second Marquess (descended from Peter, second Earl of Altamont by Eliz., only child and heiress of Denis Kelly, Chief Justice of J.), born 1788, succeeded 1809, mar. 1816 Hester Cath., first daughter of John Tho., eighteenth Earl of Clanricarde, was Governor of J. 1834-6, and died 1845. F. 4032 is a different plate.

440. "Charles Kerr, JaMalca. 17[72]" Wreath and ribbon, engraved label. The 72 written in ink. (F., 17,075.) W.E.B. gives the date as 1769 .

441. "Malcolm Laing. Trin. Coll. Cambridge" Arm. (F., 17,417.) Arus.-Argent, three piles in chief Azure.

Of Kingston, Receiver-Gen. of J. 1763, died 1781, aged 63. (Archer, 85.)

442. "Mrs. Elizabeth Lawes" Jac. arm. (F., 17,728.)

ARMs. - Or, on a chief Azure three stars of six points. On an inescutcheon : Or, a lion rampant Sable debruised of a bend Gules, thereon three escallops [GibBons].

James Lawes, elder son of Sir Nich. Lawes, Governor of J., born 1697, Lieut.Governor, mar. 1720 Eliz., only dau. and heiress of Wm. Gibbons of Vere, and died 1733. She remar. $1742 \mathrm{Wm}$., eighth Earl of Home.

443. "Temple Lawes EsQ"

A very rare plate, of which it is believed only one example is at present known, bears the name as given above, upon the motto ribbon. Just above the plate line at base is : "1741 I.S. (in ligature) kin ${ }^{r}:$ Sculpt." (E.L.J., xviii., 88.) Younger brother of James Lawes, bap. 1699, mar. 1730 Mary Butler, and died 1754. 
414. "Rich $J_{\perp}$ s Lawerce* Hughes fecit" Chip. arm. spade shield. (F., 17,765.) Engraved about 1730. (Fincham.)

Anus.-Aigent, a cross raguly Gules.

Uf Fairfield, J. Born 2t Oct. 1745, mar. Mary, fourth dau. of Tho. Hall of Kirlipatrick and WVorcester, J., and died 1830, aged 85. Father of Charles.

445. "George Lawrence" Arm. (W.F.L.)

Anus.-Argent, a cross raguly Gules, a crescent for difference; impaling, Or, a lion rampant debruised of a bend Sable, charged with a buckle between two mascles [Spexce]. Crest and Motto of Lawrence.

Second son of Rich. Jas. Lawrence, born 1775, of Cowesfield House, co. Wilts, mar. Sarah Brissett, dau. of Pat. Spence, M.D., of the parish of W cstmoreland.

446. "Charfes Lawrexce" spade arm. (F., 17,755.)

Arms of Lawrence, a mullet Gules for a difference.

Crest.-A pike's tail couped erect.

447. "Chardes Lawrence" Chip. arm. modern. (F., 17,754.)

Arms of Lawrence with a mullet for difference, impaling Gules, an eagle displayed, on a chief' Argent three trees [D'A GUILAR].

Crest of Lawrence. Motro.--IY CRUCE SALUS.

Third son of Rich. Jas. Lawrence, born 1776, of Fairfield, J., and Mossley Hall, Liverpool, inar. 1800 Rose, dau. of S. D'Aguilar.

448. "J. 'Thakp Lawrence. Hazelimph" Arm. (F’.C.; Allen, 4.74.)

ARMr.-Quarterly of six: I. Argent, a cross raguly Gules, on a chief of the second a lion passant guardant of the first. II. Argent, two bars, and in chief three mullets Gules [Washingtor]. III. Argent, two bars Vert between nine martlets [MLnE]. [V. Sable, on a bend between two bendlets Argent three walnut leaves proper [WALLER]. V. Azure, a chevron lozengy between three crossescrosslet. VI. Argent, three falcons.

1. Crest of Lawrence. 2. CREST.- $A$ tree, and on a shield suspended therefrom Azure three fleurs-de-lis. Motto of Lawrence.

449. "John Tharp Lawrence F. Adolpho. 134 Oxford Strl." Arm. on mantling. About 1804-1810. Not in Fincham. The surface of the paper green. Another specimen on India paper.

Arms, quarterly of six as in preceding.

Son of James Lawrence of Hazelymph Plantation in J. by Mary Brissett, mar. Julia, dau. of Jas. Ricketts of Ridgeland in the parish of Westmoreland, and died in U.S.A. 1847.

450. "Arthur Johnstone Lawrence" Arm. (W.F.L.)

Arms of Lawrence with a martlet for a difference, impaling Argent, on a chevron Sable three quatrefoils Argent [ErRE].

Crest of Lawrence, per pale Gules and Argent.

Motto of Lawrence-THE ORDER OF THE BATH.

Third sun of Chas. Lawrence of Mossle! Hall, Liverpool ; K.C.B. and MajorGeneral, purchased Foxhills, Chertsey, about 1872, mar'. Jacyntha Charlotte Eyre, and died 189t-5.

451. " Ti KenNedr Lawrie" Arm. (H', 17,776.)

Arars.-Quarterly : 1 and 4, Per cheoron (reversed) Or and Sable, in base a cup wreathed with laurel between two crosses pattée [LawnIE]; 2 and 3, Argent, on a chevron Gules, between three crosses-crosslet fitchée, a pine-apple between two plates [KENNEDY].

* Mr. W. F. Lawrence of Cowesfield, Silisbury, has all the following plates, except that of J. T. Lawrence of Hazelymph. 
Cnests.-1. An oak trunk fessways ensigned with a cross pattée fitchée entwined with a laurel branch. 2. A dolphin naiant, behind it a laurel.

MotTo.-INDUSTRIA ATQUE Fortuna.

Of Red Castle, Galloway, and J., died 1811, aged 62. (Ante, I., 29.)

452. "W. B. K. Lawrie of Woodhald" Arm. (F., 17,775.)

The same coat as above.

453. "MatThew Lewis EsQR ${ }^{\mathrm{R}}$ "Wreath and ribbon arm. (F., 18,248.)

Arus.-Quarterly: 1 and 4, Sable, an eagle displayed; 2 and 3, Or, two bars Azure, in chief a lion passant with a crescent for a difference [GREGORT].

Crest.-On a chapeau turned up Ermine an heraldic tiger.

Second son of $W \mathrm{~m}$. Lewis by Jane, eldest dau. of Mathew Gregory, born 1750 , Dep. See. for War, mar. Anna Maria, dau. of Sir Tho. Sewell, Knt., Master of the Rolls, and died 1812 .

454. "Willidar Lewis .JUN ${ }^{\mathrm{B}}$ " Festoon arm. (F., 18,264.)

Single coat and Crest of Lowis.

455. "The Bishop of Jamaica. Griffiths \& Weigalls 3 St James' $S^{t}$. Lond ${ }^{n}$." Arm. (F., 18,366; Allen, 421 ; E.L.J., ii., 144.) Engraved about 1830 (Fincham).

ARurs.-Gules, in fess a key and pastoral staff saltirewise, an open Bible at centre point, in chief a lion passant Or, in base a pine-apple [THE SEE]. Impaling : Azure, on a pale Argent, between in fess two falcons' wings addorsed, three crosses pattée Gules, on a chief Or two roses of the third [LIPscours].

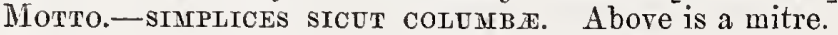

Chr. Lipscomb born 1781, Bishop of J. 1824-1843.

456. "SAnuel Long" Jac. arm. (F., 18,665.)

Arms and Crest of Long. Perhaps of J., and died 1757.

F. 18,666 has "Esq" "added. F. 18,676 is a similar plate without inscription.

457. (Lorg). Anonymous. Chip. arm. (F., 18,677.)

Arms and Crest as in F. 18,667. Motro.- SERo SED SERIo.

The shield is enclosed between two pine-apples.

458. "Beeston Lone Esq ${ }^{\mathrm{B}}$ " Arm. spade shield. (F., 18,638.)

A RMs. - Single coat of LoNG.

Born 1710, and died 1785, leaving a son of the same names, who was of Coombe House, and mar. 17\$6 Miss Neave.

459. "SAMUEL LoNG" Wreath and ribbon arm. (F., 18,667.)

Arms and Crest of Long. F. 18,668 is the same plate reworked, the lion holding a long cross flory fitchy Or.

460. "Edward Beeston Long" Arm. spade shield. (F., 18,653.)

ARMrs.-Long, with Thomlinson on an inescutcheon as in F. 18,654.

Of Hampton Lodge, co. Midd., born 1763, mar. Mary, dau. of John Thomlinson, M.P., and heiress of her grandfather John Thomlinson of East Barnet, co. Herts, and died 1825 .

461. "Edward Beeston Long Esq" Arm. spade shield. (F., 18,654. Illustrated in E.L.J., xviii., 23, by F.C.)

Arus.-Quarterly : 1 and 4, Sable, a lion passant Argent, in the dexter paw a cross-crosslet fitchy Or, on a chief of the second three crosses-crosslet of the field [Lovg]; 2, Per fess Or and Gules, a pale counterchanged, throe Cornish choughs 
proper, a mullet for difference [TムTE]; 3, BECkFond. On an inescutsheon: Per palc Vert and Argent, three greyhounds courant counterchanged, a chief engrailed $\mathrm{Or}$ [ThourLinsov].

Crest.-Out of a coronet Or a lion's head Sable, guttée Argent.

462. "EDward Loxg" Alm. (F., 18,652.)

Arss.-Quarterly : 1 and 4, Lorg; 2, 'IATE; 3, Gules, nine bezants, a canton Ermine [Zodche]. On an inescutcheon, Beckford. Crest of Long.

MIOTTO.-PIEUX QOIQUE PREUT.

Born 1734, Judge of the Vice-Admiralty Court, J., 1760, Speaker 1768, Historian of J., mar. 1758 Mary Ballard, second dau. and coheiress of Tho. Beckford and widow of John Pallmer, and died 1813.

463. "Charles Lovg EsQR" Arm. spade shield. (F., 18,639.)

Arus.-Loxg, impaling, Quarterly: 1 and 4, Vert, a lion rampant Argent; 2 and 3, Argent, three falcons [HuME].

464. "Charles Lovg, Hurts Hall" Arm. (F., 18,643.)

Arurs.-Quarterly: 1 and 4, LoNa; 2 and 3, Azure, a lion passant between three fleurs-de-lis Argent [NoRTH], impaling LoNg.

Of Saxmundham, co. Suffolk, mar. 17 2 .Jane, second dau. of Beeston Long, - and died 1813.

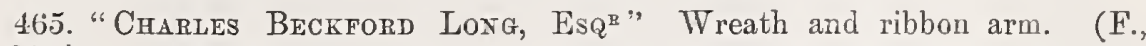
18,641.)

ArMs.-Quarterly : 1 and 4, LoNg; 2, TATE; 3, BECKFord. On an inescutcheon: 1 and 4, Barry wavy on a chevron crenellée, between three sea horses, seven guttées de poix [T-CCKER]; 2 and $3, O r$, an eagle's head erased Gules, a mullet Azure for a difference [Morro]. Crest of Long charged with a mullet.

Third son of Edw. Long by Mary Ballard Beckford, mar. Frances Monro, dau. anc heiress of Lucius Tucker by Frances, dau. and heiress of $\mathrm{Wm}$. Jenkyns, and died 1836, aged 65 .

466. "Charles Beckford Lowg." Arm. (F., 18,645.)

Arus.-Quarterly of twelve: 1, Long; 2, TAte; 3. Zouche; 4, Argent, two chevrons Gules, a label of five points Azure [ST. MAuR]; 5, Gules, three leopards' faces jessant-de-lis reversed; 6, Sable, a fess Argent between three fleurs-de-lis; 7, Gules, three lozenges Ermine; 8, Sable, three lions rampant, two in chief, one in base, between nine crosses-crosslet Argent; 9, Gules, a cinquefoil Ermine; 10, Or, a lion rampant between two tressures Gules; $11, A$ cross flory $O r$ between four martlets; 12, BEckFord. On an inescutcheon, Quarterly: 1 and 4 [TUCKER]; 2, Or, a lion rampant reguardant Sable [Jeskrss]; 3 [Monro]. MotTo.-PIEUX QUOIQUE PREUX.

F. 18,646 is the last plate with the Crest reworked.

467. (Long). Anonymous (Cleghori). Arm. (F., 18,680.)

Arirs.-Quarterly: 1 and 4, Lovg; 2, TAte; 3, Zouche. Motto.

468. "Right Hororable Sir Charles Loyg, G.C.B." Arm. two shields accolé with supporters. (F., 18,640.)

469. "Right Honourable Lord Farnborodgh" Arm. two shields accolé. (F., 18,637.)

Arurs.-I. Love. II. Lovg, impaling Hume.

Sir Chas. Long, G.C.B.. was created a Baron 1826, mar. 1793 Amelia, dau. of Sir Abr. Hume, Bart., and died 1838. 
470. "Robert B. Loxg." Arm. (F., 18,661.)

Arms, Crest and Motto of Long, with a mullet for difference.

471. George William Prescott. Arm. spade shield in a beaded oval. (F., 2ł,066 and F.C.)

Anus.-Sable, a chevron Argent between three owls, impaling Lovg of J.

CREST. - A cubit arm erect, cuffed Ermine, in the hand a pitch-pot fired.

He mar. 1774 Sarah, dau. of Beeston Long of Carshalton and London, merchant, created Bart. 1794, and died 1801. She died 1817.

472. "Charles Devon." Arm. (F., 8,567.)

Anirs.-Quarterly : 1 and 4, Checky Or and Azure, a fess Gules; 2 and 3, Sable, two bars Ermine, on a chief indented per pale Or. and Argent an eagle displayed of the first [BARLow of Sheffield]; impaling, Quarterly : 1, Sable, a lion passant Argent, in the dexter paw a cross-crosslet fitchy $O r$, on a chief of the second three crosses-crosslet of the field [Lowg of J.]; 2, Per fesse Or and Gules, a pale counterchanged, three Cornish choughs proper [TATE]; 3, Gules, ten bezants, 4, 3, 2 and 1, a canton Ermine [Zovch]; 4, Per pale Gules and Azure, on a chevron Argent between three martlets an eagle displayed Salle [BECKFORD of J.].

CREST.-A lion rampant, gorged with a mural coronet.

MotTo.-NON SIBI SOLUM.

Of Rackenford, co. Derosl, mar. in 1822 Mary, dau. of Edw. Becston Long of Hampton, co. Middlesex, and J. ? F. 8568 with inscription altered.

473. "Lopes" Arm. (F., 18,720.)

Anus.-Quarterly: 1 and 4, Azure, a chevron Argent charged with three bars gemel between as many eagles rising, on a chief of the second five lozenges of the first [Lopes]; 2 and 3, Argent, a fountain in a landscape [Franco]. Badge of Ulster.

CREsTs.-1, A lion sejant Erminois supporting with the dexter paw a lozenge Azure; 2, An arm embowed, vested, couped, in the hand a palm branch.

MotTo.-QUOD TIBI ID ALII.

Sir Ralph Lopes of Maristow, co. Deron, succeded his uncle, the first baronet, in 1831. The former was son of $\mathrm{Abr}$. Franco by Esther Lopes, all Portuguese Jervs of J.

474. "Percr Lousadi, Mert. Colt." Arm. (F., 18,745.)

Arus. - Azure, on a chevron between three doves reguardant Argent, wings expanded, two sugar canes, impaling: Argent, three bars Gules, in chief a greyhound courant [SкIPWIтн].

CREST.-A like dove, in its beak a sprig.

Motto.- - Spernit Pericula virtus. Arms confirmed in 1777 (Burke's "Heraldic Tllustrations," 89).

The Rev. Percy Murtindale Lousada, only son of David Lousada, matric. from Merton Coll., Oxf., 1841, aged 18, student of the Inner Temple 1844, mar. 1848 Mary Eliza, second dau. of M. Gutteres of Sidmouth, and died 1859, aged 36. They were Portuguese Jews.

F. 18,746 is the last plate printed in gold on dark blue paper.

F. 18,747. Arms, Lousada quartering skipwith.

475. "Benjayin Lron" Pict. arm. (F., 18,977.)

Arus.--Argent, a lion rampant Azure within a tressure flory; impaling, Azure, a chevron Or between three garbs [Coursss].

Crest.-A demi-lion affrontée couped, in dexter paw a dagger and in sinister one a cross. MotTo.- SPES MEA IN CHRISTO.

He owned St. Jago Park, J., and his will was proved in 1780, but there is no clue iu it to his wife's name. 
476. "Benjanin Lron." Spade shield within a wreath.

single coat of Lyon and Crest. No motto. (F.C.)

477. "ZACHART MIACAULAY" Arm. (F., 19,0S5.)

Arurs.-Gules, two arrows in saltive, surmounted of a fess checky of the second and first between three buckles within a bordure indented Or.

CrEst. - A booted foot couped at the ankle and spurred.

Motro. - DUlCe periculuir.

Born 1768, resident in J. 1784-1792. Abolitionist and Philanthropist. Father of Lord Macaulay, and died 1838. ("D.N.B.") Also a smaller plate.

478. "MIcN NIR" Festoon.

Crest.-A negro holding a branch of sugar-cane. (W.E.B.)

479. "Richalld Robert Madden" Arm. (F., 19,434.)

ARMs. - Sable, an eagle with wings expanded preying on a heron, on a chief or a cross-crosslet Gules.

CREsT.-Out of a coronet an eagle standing with wings expanded, in the beak a cross-crosslet. MotTo.-FIDE ET FORTITUDINE.

Born 1798, writer, special J.P. in J. 1833-4, F.R.C.S. 1855, author of several works on the W.I., mar. 1828 Harriet, youngest dau. of John Elmslie of J., and died 1896. ("D.N.B.")

480. "Gilbert Mathison" Arm. (F., 19,996.)

ARMs.-Gyronny of eight, Sable and Giules, a lion rampant within a bordure Argert, charged with eight crosses-crosslet fitchy of the first; impaling, Argent, a lion rampant between in chief two sinister hands couped, and in base a crescent.

CREST.-A hand erect couped, holding a falchion fessways [FARQUHAR].

MoTTO. - FAC ET SPERA.

Mar. Cath., dau. of Sir Walter Farquhar, 1st Bart. She died in 1849. Gilbert Matthison, Assistant Judge of St. Jago-de-la-Vega, died in 1774, perhaps father of the above.

4S1. Emanuel Mendez $D_{A}$ Costa. Chip. arm. (F., 20,350.)

ARMIs. - Gules, the upper halves of six thigh-bones couped fesswise, the cut ends neeting in the centre pale, 2, 2, and 2, a canton Ermine and a martlet charged with a crescent for cadency.

CREST.-Out of an antique crown a plume of ostrich feathers.

Motro.-GRACIA DEI SUPFICIT MIE.

F. 20,352, 3, 4, and 5 all have the same arms, but with various mottoes. One of these plates has been illustrated in E.L.J., xv., 27, 43.

The will of Lady Rebecca M. da Costa of J. was proved in 1792. They were Portuguese Jews.

482. "Isanc Mendes. London. 1746 Levi sculp." Chip. al"m. (F., 20,351.)

Arms as above, but the joint ends meeting in the centre pale. Crest and Motto.

Two states. (F.C.) Fincham omits "London."

483. "Henry Moore" Jac. arm. (J.M.)

Arms and Crest of Moore. It also occurs without the name. (F.C.) F.C.)

484. " $\mathrm{S}^{\mathrm{r}}$ Henry Moore" Chip. arm. (Illustrated in E.L.J., xviii., 24, by

ArMs. - Argent, three greyhounds courant, impaling Lora.

CREST. $-A$ moorcock, in its beak a sprig.

Born 1713 in J., graduate of Leyden 1731, Lieut.-Gov. of J. 1756-61, created Baronet 1761, Gov. of New York 1765, mar. Catherina Maria, dau. of Sam. Long of $\mathrm{J}$. , and died 1769 . 
485. "Lady Moore" Festoon arm. lozenge. (F., 20,995.) (Illustrated in E.L.J., xviii., 23, by F.C.)

Arms as above. Widow of Sir Henry.

456. "Henry Moore" Arm. shield on a mantle. (F., 20,979.)

487. "Edward Morant. Brockenhurst 1764" Landscape arm. (F., 21,023.) Engraved about 1825. (F.C.)

Anus.-Gules, a fess Argent, fretty Azure, between three talbots sejant Or. On an inescutcheon: Gules, a chevron vairé between three crescents [GODDARD].

Edward Molant, Senr., born 1727, M. of C. of J. 1757-60, M.P., mar. 2ndly in 1762 Mary Whitehorne, dau. and coh. of Dr. Jas. Goddard of J., and died 1791, leaving a second son Edward, to whom the plate must have belonged. The date 1764 probably refers to the purchase of the Brockenhurst estate. See "Hamilton," under 1764, 1786, 1825, and 1862.

488. "John Morant 1786" Arm. landscape. No Motto. (Hamilton.)

489. "JoHn Morant 1825 " Arm. pictorial.

Motto.-EN MOURANT J'ESPère. (Hamilton.)

490. "John Morant. 1862." Arm. (F., 21,025 and Hamilton.)

Arms.-Morant, impaling, Quarterly, 1 and 4, Azure, three fleurs-de-lis Or; 2 and 3, Gules, three lions passant Or within a bordure Azure and Argent [Somerset]. Crest and Motto of Morant.

Of Brockenhurst, born 1825, mar. 1855 Lady Henrietta Louisa, 3rd dau. of the 7 th Duke of Beaufort.

491. "George Morant" Crest. (F., 21,024.)

Crest.-A dove, in its beak an olive branch.

Of Farnborough Place, Hants, died in 1846, aged 76.

492. "J. Lushington Morant" Crest. (F., 21,026.)

493. "Munbee" Arm. (F., 21,316.)

Anus. - Azure, fretty Or, on a canton Gules a cross moline.

CREST.-An Indian affrontée, couped at the shoulders, a plume of six feathers on his head, a necklace around his neck, and a sheaf of arrows behind his left shoulder. MotTo.-FORTITER ET NECESSE.

Major Valentine Munbee of J., mar. in 1702 Eliz. Dawkins, and another of the name (perhaps his son) mar. in 1721 Bridget Beckford, and died 1778.

494. (Munbee). Anonymous. Arm. (F., 21,317.)

Arms. - Munbee, impaling Azure, a dolphin, on a chief Or two saltires humettée Gules [FRANKLAND].

CREST.-An Indian voman couped at the shoulders, on her head a plume of six feathers, a necklace around her neck, and a cloth across the breasts looped over the left shoulder.

Capt. Gore Boland Munbee of the Bombay Engineers mar. 1846 Sophia Cath., dau. of the Rev. Roger Frankland.

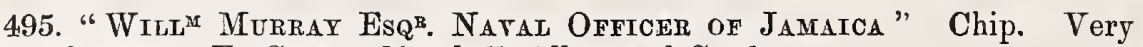
rare, unknown to F., Carson, Marshall, Allen, and Cattle.

M. of Assembly 1765, Naval Officer 1766. (W.E.B.)

496. "George Murrax. Westmoreland, Jamaica" Festoon arm. (F., 21,412.) 
Arus.-Azure, within a tressure flory a chevron or between three mullets Argent, a crescent for a difference.

CREST. - A culit arm erect, in the hand a star of eight points Or.

MotTo.-LUX E TENEBRIS.

Assistant Indge of Savanma la Mar, mar. 1775 Cath. Gordon, and died 1804, aged 75 . (Archer, 337.)

497. "Johr Nixor Summer Street" Chip. arm. (F.C.)

The same Crest and Arms of Nixon, the axe Sable.

498. "Johr Nixon" Arm. shield on clouds. (F., 21,914.) Engraved about 1790 to 1800 .

ArMs. - Sable, five plates, 2, 2, and 1, in chief Argent a battle-axe fessways; impaling, Argent, an eagle displayed. CRest.-A cock.

Col. of Horse and Judge in J., died 1774, too early for the plate.

499. "George Nugent" (F., 22,090.)

ArMs.-Ermine, two bars Gules. CREst.-A cockatrice.

MotTo.-DeCRevi.

F. 22,085 and F. 22,089 may also be his.

500. "Sir George Nugent" Crest in a garter. (F., 22,091.)

Crest of Nugent. Badge of Ulster and Motto of the Bath.

Natural sou of the Hon. E. Nugent, born 1757, Lt.-Gov. of J. 1801-6, created Baronet 1806, G.C.B. 1815, M.P., F.M. 1846, and died 1849. ("D.N.B." and Diary of Lady Nugent.)

501. "Admirat Nugent" Crest. (F., 22,092.)

Crest of Nugent.

Sir Cha. Edmund, younger brother of George, born 1759, served much in the W.I., M.P., Admiral 1808, Admiral of the Fleet 1833, and died 1844. ("D.N.B.") Another plate.

502. "Anna Perronella Ord" Chip. arm. (F., 22,358; illustrated iu E.L.J., vi., 143.)

ARMs.-Sable, three salmon erect, impaling, Per pale Gules and Vert, an eagle displayed [Elletson]. Crest.-A buck's head couped.

Dan. of Roger Elletson and widow of Ogle of J., mar. James Ord, who was M. of A. 1744 and 1749 , and died 1772 .

503. "N. T. OrGill. M.A." Arm. spade shield. (F., 22,386.)

Aris.-Quarterly: 1 and 4, Argent, a fess Gules between three crescents, each charged with a fleur-de-lis; 2 and 3, Azure, a fess Argent between three dolphins naiant [LEMas], impaling, Argent, a chevron between three crosses-crosslet flory [Anderson]. Crest.-A buli's head erased. Motto.-тenebo.

The Rev. Naunton T. Orgil mar. 1783 Henrietta Jane, dau. of Sir Wm. Anderson, Bart.; assumed the surname of Leman in 1807.

504. "Taures Pedder, Bath, Jamaica" Label. (W.E.B.)

505. "JAMEs Pedder" Arm. (F., 23,097.)

Arms.-Quarterly: Sable and Gules, on a bend Argent between two escallop: a greyhound courant between as many cinquefoils of the second.

CREst.-Between two olive branches as many lions' heads erased, addorsed, gorged with one collir. MOTTO.-JE DIS LA VERITÉ.

Died 1775, arred 6t (ante I., 77), but the plate is later. The arms of Jas. Pedder of Ashton Lodge, co. Lanc. (Burke's "Armory.") 
506. "Edward Gordon Dovglas Pennant" Arm. (F., 23,197.)

ARus.-Quarterly: 1 and 4, Per bend sinister Ermine and Ermines, a lion rampant Or, a canton Sable [Pennast]; 2 and 3, Douglas, Eart of Morton, quartering, Argent, three piles Gules, the dexter and sinister charged with a mullet [Dovgras of Dalkeith]; impaling Fitzroy.

CREST.-I. Out of a coronet an heraldic antelope's head charged with a crosscrosslet; II. A wild boar statant padlocked to a tree, with the motto LOCK SICKER.

Motтo.- - EQUO ANIMIO.

Born 1800, assumed the surname and arms of Pennant 1841, created Baron Penrhyn 1866, mar. 2ndly, in 1846, Mary Louise, dau. of Heury, 5th Duke of Grafton.

507. "Will: Hen : Ricketts" Early Chip. arm.

ARMs.--Argent, a chevron between three roses Gules.

Crest and Motto of Ricketts as in F. 24,991.

508. "Wilt. Hen. Ricketrs" Chip. arm. (F., 24,991.)

Arins of Ricketts with a mullet for a difference.

Crest.-An Indian couped at the shoulders, vested, and on the head a turban.

MOTTO.-QUTD VeRUM ATQUE DECENS.

Born 1740, M. of C. of J., of Longwood, co. Hants, beneher of Gray's Inn 1769, granted arms 1773, mar. 1757 Mary Jervis, sister of John, Earl St. Vincent, and died 1798.

509. "WrLi HeNhy Ricketets" Chip. arm. 18 . . watermark in paper. (F., 24,992.)

Arins, Crest and Motto as above.

Son of the preceding, born 1764, Capt. R.N., mar. 1793 Lady Eliz. Jane Lambart, dau. of Rich. C., Earl of Cavan, assumed the surname of Jervis 1801, and was drowned 1805.

510. "Mrs Porntz Ricketts, Baker Street" Engraved label. (F., 24,989.)

Probably Sophia, dau. of Governor Watts, who mar. 1772 Geo. Poyntz Ricketts, Governor of Barbados. If not, she may have been Sophia Peirce, who mar. 1800 Geo. Poyntz Ricketts, junr.

511. "Mordaunt Ricketts" Arm. (F., 24,988.)

A RMs.-Quarterly : 1 and 4, Or, on a chevron Gules two swords between three roses; 2 and 3, Barry of eight Or and Gules [Porntz].

CREST.-An ar'm in armour, embowed, in the hand a sword. MIotto as above.

Third son of Geo. P. Ricketts, Governor of Barbados, of the E.I.C.S. 1812. His paterual grandmother was Hannah, dau. and coheiress of Joseph Poyntz of J.

512. "Geo ${ }^{\mathrm{B}}$ Widi $\mathrm{M}$ Ricketts. Trin. Coll. Cambridge. Holland Sculp." Arm. spade shield. (F., 24,986.) Engraved about 1780. (Fincham.)

Anus. - Ermine, on a chevron Gules two swords, points to centre, between three roses.

CrEst.-An arm embowed Ermine charged with two cinquefoils, in the hand a sword. Motto as above.

Son of Geo. Crawford Ricketts of J., born 1791, Judge at Madras, knighted 1825, died at sea 1832. Father of Sir Henry Ricketts 1802-1886. ("D.N.B.")

513. "Francis Hate Rigbi" Arm. (F., 25,045.)

ARMs.-Quarterly : 1 and 4, Argent, three bends indented Azure, on a chief Sable three cinquefoils; 2 and 3, Azure, a chevron embattled and counter-embattled Argent [HALE].

Crests.-I. An antelope's head erased. II. Five arrows with a serpent entwined, one in pale, four in saltire. 
514. "F. H. R. Mistleer Hall" Engraved label. (F., 2.5,046.)

Son of Lient.-Gen. Bernard Hale by Martha, dau. of Ri»h. Rigby, Prov.Mar.-Gen. of J., Lieut.-Col., and took the surname and arms of Rigby on succeeding in 1788 to the estate of Mistley Hall on the death of his uncle the Rt. Hon. Rich. Rigby, P.C., M.P., mar. Frances, dau. of Sir Tho. Rumbold, Bart., and died $182 \pi$.

515. "Eben Robertson. Kingston, Jamaica." Chip. arm. (F., 25,189; Allen, 736.)

A RIS.-Gules, three wolves' heads erased dropping blood.

Crest.-A hand erect couped, holding a royal crown.

Motto.-virtutis gloria merces. Under the shield a wild mial chained.

Ex'or 1798 of $\mathrm{Wm}$. Baillie of J.

516. "Eber Robertson" Arm. (F., 25,190; Allen, 735.)

A smaller plain shield. Arms, Crest, and Motto as before.

517. "Sir Joshua Rowe" Arm. (F., 25,617.)

Arurs.-Gules, three holy lambs; impaling, Sable, a fess engrailed between three hands bendwise Or. Bate]. Crest.-A holy lamb.

Mотto.- sub CRUCE VINCaMr. F. 25,618 has in addition the badge of the Bath.

Chief Justice of J. 1832-56 and died 1874, aged 77, his widow Frances Ann surviring (ante, I., 217).

518. "Mart Eliz" Campbell" Arm. (F., 5020.)

ARMs.-Gyronny of' eight Or and Sable, within a bordure engrailed, divided as the gyronny of eight of the first and Azure, charged with five buckles; impaling, Checky Or and Gules, a lion rampant Ermine, a canton Azure [SCARLETT].

Eldest dau. of the 1st Lord Abinger, mar. 1821 Sir John Campbell (later a Baron), was created Baroness Stratheden 1836, and died 1860.

519. "Alex ${ }^{B}$ SCHAw EsQR" Jac. arm. (F., 26,214.)

ARMS.-Azure, three covered cups with a crescent for difference.

CREST.-A demi-savage wreathed abont the head and loins with laurel, and holding a elub over the dexter shoulder. МГTTO.-I MEAN WELL.

Perhaps connected with the Schaws of Schawfield plantation. I have in MS. the Tour in 1774-78 through the W.I. by Miss Jen. Schaw, sister of Alex. Schaw, Esq.

520. "Benjamre Scotr" Chip. arm. (F., 26,267; Allen, 764.)

AnMs.-Argent, a cross-erosslet fitchy Sable.

Crest.--An eagle standing on a crane lying prone.

Perhaps of J., where he died 1825, aged 91, having freed 83 of his negros.

521. "David Shakespear Hill sc." Festoon arm. (F., 26,548.) Engraved about 1780. (Fincham.)

Anus.-Or, on a bend Argent a tilting-spear; impaling, Argent, two bendlets embattled and counter-embattled Sable.

Crest.-An eagle with woings expanded, in the dexter paw a tilting-spear in pale. Motro.-FIDE SED CUI VIDE.

Of Hodges plantation. His wife Cath. died in 1805, aged 47.

522. "Thomas Frederick Stmmons" Arm. (F., 26,963.)

Arss.-Quarterly : 1 and 4, Sable, a dolphin naiant embowed; 2 and 3, Argent, on a cross Gules five roses [Lintory]; impaling, Argent, on a chevron Azure, between three lions rampant Gules, as many bugle horns of the first [PERRY].

Ciest.-A broken oak trunk erect, surrounded by a sprig.

Motto.- Stabilitate et victoria.

Capt. R.A. of Langford, co. Som., mar. Mary, dau. of the Hon. John Perry, a Judge in $J$. 
523. "Hans Sloane Esq." Spade shield arm. (F.C.) ? A wood block and not copper.

ArMs.-Gules, a sword in pale, point downwards, between two boars' heads couped at shoulders erect, Or, on a chief Ermine a lion passant of the first between as many mascles Sable.

Sir Hans Sloane, Bart., born 1660, died 1753, s.p.m. Wm. Sloane of Stoneham, Hants, mar. 1733 Eliz., dau. of John Fuller of Brightling, Sussex, by Eliz., 1st dau. and coh. of Dr. Fulke Rose of J., and their son Hans Sloane, M.P. 1768 -1806, mar. 1772 his cousin Sarah, dau. of Stephen Fuller, A gent for J. (Crisp's "Visitation," Notes, ix.)

524. "Aubrey Geo. Spencer. Oxon." Arm. (W.E.B.)

525. "Aubrex G. Spencer D.D. Archdeacon of Bermeda" Arm. Two states.

Born 1795, of Bermuda 1812 to 1839 . (W.E.B.)

526. "Bisuop SPencer" Name and mitre. (F., 27,702.)

His first plate after being consecrated Bishop in 1839. (W.E.B.)

527. "Aubrey. NewFoundeand" Arm. mitre.

Bishop of Newfoundland 1839 to 1843 . (IV.E.B.)

528. "AuBRET G. JAMAICA" "Wyon" Arm. mitre. (T., 27,701.)

Arus.-Argent, a pastoral staff and key in saltire debruised by an open Bible between a lion passant and a pine-apple [the SEE of J.]; impaling, Quartenly. I. and IV., Quarterly Argent and Gules, a fret Or, over all a bend Sable charged with three escallops; 2 and 3, Sable, a lion rampant, on a canton Argent a cross Gules.

Crest. - A mitre.

The whole shield is over a donble-headed eagle Sable crowned with ducal coronets, and each head resting on a bezant.

Bishop of J. 1843 to 1856; died in Torquay 23 Feb. 1872, and his marble bust is in Exeter Cathedral.

529. (Spencer.) Anonymous. Axm. The plate of F. 27,701 without inscription. (F., 27,721.)

530. (Storer.) Anonymous. Arm. (F., 28,295.) A moderu steel plate.

Arurs.-Quarterly: 1 and 4, Per fess Argent and Gules, a pale counterchanged, three cranes of the first; 2 and 3 , Or, a lion rampanl requardant, in its dexter paw a cross-crosslet [MonRIS]; impaling, Quarterly, 1 and 4, Sable, a cross engrailed Or [WILloUguвг]; 2 and 3, Gules, a cross moline Argent.

Crest. - A crane.

Anthony Morris Storer of Purley Park, co. Berks, mar. 1860 Cicely Barr, dau. of Sir John Pollard Willoughby, 4th Bart. Anthony Storer, the first settler, born 1675, mar. Eliz. Anna Maria, dau. of Col. Sir Chr. Morris of J., and died 1719.

531. "Anthont Langley Swtmer, EsqR. of Mold in the county of FLINT" Jac. arm. (F., 28,675.)

ARMs.-Gules, three bells.

Crest.-A demi-lion rampant couped, between its paws a bell.

From Bristol, mar. Arabella, 5th dan. of Sir John Astley of Patshull, co. Stafford, Bart.. and died in J. 1740, aged 34. His son of like names was of St. Peter's Coll., Camb., 1744, M.P. for Southampton, and died 1760 in J.

532. "Ww Leigh Srares EsQR." Arm. spade shield. (F., 28,729.)

ARMs. - Ermine, three de-crescents.

CREsT.-A man's head in a helmet with the vizor raised.

Died 1796 at his plantation, Oxford St. Mary's in J. 
533. "T" W. Darling fec . Great Newport $S^{t}$. Arm. Engraved about 1770. (Fincham.)

534. "J. I'(ALLOR)." First state. Taylor coat only, no Badge of Ulster. Festoon supporters. (F.C.)

535. "J. T(AYLOR)." (F., 28,994). Second state. Ulster Badge added. (F.C.)

536. “J. T(AYLOR)." (F., 28,995.) Third state. The same, with Houghton on an inescutcheon added. (This is the same plate, not a Chip. as stated in Catalogue.) (F.C.)

537. “E. T(ATLOR)." (F., 2S,976.) Fourth state. Same plate again reworked. (F.C.)

538. "Sir J. Taylor (of Lysson Hali, Jamaica)" Arm. (? style).

Arms. - Single coat with Badge of Ulster.

Crest and Supporters and Latin Motto.

Born 1745 in J., created Bart. 1778, F.R.S., died at Kingston, J., 17S6. Plate sent me by a dea?er.

539. "Lady Taylon" Arm. lozenge.

Arms.-A similar design, but on an inescutcheon [Houahtor]. (Ibid.)

540. "Simor Tarlor" Arm. (F., 29,022.)

A Rurs.-Single coat, a crescent for difference. Crest and Latin Motto.

Brother of Sir John, died 1813, aged 73. (Archer, 136.)

541. "S. R. B. T. Thompson sc. Gt Newport St." Festoon, arm., supporters. (F., 29,024.) Engraved about 1790. (Fincham.)

Aris.-TaYlor quartering Hovghton, Latin Motto.

542. "Sir SiMoN TAXLOR" Arm. supporters. (F., 29,023.)

ARus.-Quarterly: 1 and 4, Argent, a saltire wary Sable between two cinquefoils in fess and as many human hearts in pale Gules; 2 and 3, Sable, three bars Argent, on a canton Or a rose and thistle [Hovgrtos]. In centre point the Badge of Ulster.

CREST.-Out of a coronet a hand erect couped, grasping a cross-crosslet Gules.

Mottoes.-Abore: in HOC SIgNo vinces. Below: MALGRé LE TORT. Supporters: Two leoparls rampant, collared and chained.

543. "Sir Sinon R. B. Taylor, Bart." Arm. (F., 29,025.)

Arus.-Taylor quartering Hodghton. Crest, Supporters, and both Mottoes. 1815.

Sir Simon Richard Brissett Taylor, 2nd Bart, succeeded 1786, and died bach.

544. (TAYLOR). Anonymous. Arm. (F., 29,041.)

ARMS.-Quarterly: 1 and 4, TAYLOR, differenced with a canton Ermine; 2 and 3, Argent, on a mount a tree debruised by a fess Azure, charged with three mullets [WATson]. On an inescutcheon: TAYLOR quartering Houghtor.

Crest of Taylor, charged with a heart. Supoorters.

Geo. Watson mar. in 1810 Anna Susanna, dau. of Sir John Taylor, 1st Bart., and sister aud coh. of Sir Simon R. B. T.. 2nd and last Bart., whose additional surname and arms he assumed in 1815. He squandered his estate. F. 29,042 is a smaller plate.

545. "DAvid Thomson, M.D." Jac. bookpile arm. (F., 29,327.)

AnMs.-Per fess Argent and Sable, a fess counter-embattled between three falcons counterchanged. CREST.-A falcon.

Of Hallover, J., and died 1785. (Ante, II., 18.) 
546. "William Henry Twring Esq. Bryn, co. Pembroke" Arm. Originally engraved by Beckwith for Burke's "Heraldic Illustrations," and afterwards used as a bookplate. (F., 30,064.)

Arus.- Sable, two bars between as many stars of six points Or.

Crest.-The twins Castor and Pollux in infancy.

MotTo.-STElits aspirate gemellis.

Eldest son of Wm. Twyming of J., born 1810, Rector of Grosmont, co. Heref., 1855 until his death 1874. (Foster.)

547. "JonN VASsaLL EsQR" Chip. arm. (F., 30,245; E.L.J., vii., 17. Illustrated in "Antigua," iii., 446, and Allen, 114.)

A RMs.-Azure, in chief a sun in splendour, in base a chatice Or.

CREST.-A ship without saits or yards Sable, at each masthead a pennon, and at the poop the ensign flying.

Born 1738 at Cambridge, Mass., B.A. Harvard 1757, mar. 1761 Eliz., daul of Col. Robert Oliver of Antigua, and Dorchester, Mass., IV. of C., a loyalist, retired to England 1775, and died at Clifton 1797. Lie owned Newfonnd River plantation in J.

54S. "JohN VASSALL EsQ $Q_{\mathrm{R}}$ " Chip. arm. (F., 30,246.) A different plate from the last, but very similar; it has a ship with yards and furled sails. This plate occurs in blue as well as in black, and there is a rare early varjety of it with the field Argent instead of Azure in the possession of F.M. (F.C.)

549. "Fannt VASSalt" Chip. From the J.M. collection and unique.

Dau. of Wm. Vassall of J., born 1715, and died 1800. (W.E.B.)

550. "Williair Vassalil" Arm. spade shield. (F., 30,253.)

A Rirs. - The sun, very large. CREST.-The ship has three bare masts rigged.

Of Battersea. Will dated 1794, and proved 1800, names his Green River plantation in J. (680, Adderley).

551. "D $\mathrm{D}^{\mathrm{R}} \mathrm{V}_{\mathrm{SSAIIL}}$ " Arm. (F., 30,244.)

Arms and Crest. MotTo. - S SAPE PRO REGE SEMPER PRO PATRIA.

These being the ancient ones.

Wm. Vassall, Staff Surgeon R.A., born 1780, mar. 1817 Anne, only dau. of Col. Sam. Oliver of Belgrave, co. Leic., and died 1845.

552. "Spencer L. H. Vassati Esq Royal Naty. Burnell se." Arm. (F., 30,248.) Engraved about 1845. (Fincham.)

ARMs.- VASSALL, with the augmentation of: On a fess Or the breached bastions of a fortress, above which the wards "MONTE VIDEO," on a canton Argent "38th" within a branch of cypress, and another of laurel, the stems united in saltire.

New CRest.-On a mount Vert a breached fortress, thereon hoisted a flag Gules, with MONTE vIDEO in gold.

New MotTo.-EVERT BULLET HAS ITS BILLEN.

F. 30,249 is this plate reworked, with a regimental colour on either side.

553. "Captata Spencer Vassali, Royal Naty. Burnell sc." Arm. tropby. (F., 30,250.) Engraved about 1840? (Fincham.)

The last plate with inscription altered and motto added over the second crest.

Promoted to Captain 1837. Nominated a K.H. in 1837.

F. 30,251 is this plate reworked. F. 30,254, anonymous, is this plate reworked, with the badge of the Royal Hanoverian Guelphic Order added below. 
554. "Spencer L. H. Vassali." Arm., two shields accolé. (F., 30,252.) (Illustrated in Howard's "Misc. Gen. et Her.," 2nd Series, iv., 120.)

Aras.-I., Vassall ; II., Vassali, impaling, Argent, a saltire engrailed between four roses Gules [NAPIER]. Both Crests aud Mottoes of Vassall.

Sir Speucer Lambart Hunter Vassall, R.N., born 1799, Knt. 1838, mar. 1844 Letitia Sarah, only dau. of Edw. Berkeley Napier and widow of the Rev. C. H. Pulsford, and died 1846.

555. "Rawdox I. P. Vassall B. Wyon sc. 287 Regent St." Arm. (F., 30,217.) Engraved about 1850 . (Fincham.)

Arms, Crest and Motto as augmented.

Rawdon John Popham Vassall, General in the Army, younger brother of Sir Spencer, died 1894.

556. "Holland House" Arm. (F., 11,128.)

ARMs.- Ermine, on a chevron three foxes' heads erased, on a canton Azure a fleur-de-lis [Fox]. On an inescutcheon: VAsSaLl Ancient. A baron's coronet. Supporters and Motto.

Henry Richard, 3rd Lord Holland, mar. 1797 Eliz., dau. and heiress of Rich. Vassall of J., and divorced wife of Sir Godfrey Webster, Bart.

557. "Arma Edwardi Perting, et Honoria Maria Georgiand uxore EJUs." Arm. shield on a mantle. (F., 14,509.)

Arus. - Argent, two bars Azure, surmounted of a cross Gutes, thereon five lions' heads erased [Hensiow]; impaling, Quarterly, 1 and 4 , VAssali (Col. Tassall's augmented coat); 2 and 3 , Argent, a lion passant between three fleurs-de-lis [Evans], quartering, Sable, five mascles, 1, 3, and 1 [BRANDRETH].

MotTo.- OBSEQUeNs NoN VERNILIS.

Rev. E. P. Henslowe mar. H. M. G., dau. of Col. Spencer Tho. Vassall.

There are several other plates of the Henslowes.

558. "SAMUEL VAUGHAN" Jac. arm. (Illustrated in E.L.J., i., 38, Curio 11, and Allen, 890.) One red and one black. (W.E.B.)

Arus. - Sable, a chevron Argent between three boys' heads couped at the shoulders of the second, crined Or, each enwrapped about the neck with a snake Vert. Crest.-A like boy's head. MotTo.-IN pRdDentia \& simplicitate.

Sometime a planter in J., then settled in Hallowell, Maine. His son Benj. born in J. 1751, mar. 1781 Sarah Manning of St. Kitts, and his plate has been entered under that Island. He died at Hallowell in 1835.

The Hon. Sam. Vaughan, custos of St. James', J., died at Ridgeland estate 1827, after a residence of 58 years.

559. "SaMuel VAUGHai JuN" Arm. spade shield. (F., 30,277.)

ArMs.-Single coat, Crest and Motto.-PRUDenter e'T siMpliciter.

Perhaps of the above family. There is also a very similar plate belonging to William Vaughan. (F., 30,282.)

560. "Henry Garrioch Vernon Coll: Reg: Oxon." Alm. beaded oval. (F., 30,342.)

ARurs.-Or, on a fess Azure three garbs.

CREST.-A demi-woman couped, in her dexter arm a sheaf, in her sinister hand a sickle.

Son of Bowater Vernow of J., matric. from Queen's Coll. 1777, aged 18, B.A. 1784, Rector of Great Bromley, co. Essex, 1807, until his death 1837. (Foster.) F. 30,338 may be his father's.

561. "Janes Wedderburn." Chip. arm. (F., 31,222.)

Arus. - Argent, a chevron between three roses Gules. 
Crest. - An eagle's head erased.

Perhaps of J., and will proved 1799.

562. "Mrs WELCH" Arm. lozenge mutilated. (F., 31,256.)

Arms.-Azure, three mullets Or; impaling, Azure, a bear sejant, on a canton Or a cock [DEHANY].

Lucretia Favell Dehany mar. 1769 Richard Welch, Chief Justice of J., who died 1782. (Ante, II., 230.)

563. "Hon "Hon John Browne." Arm. (F., 4060.)

ArMs.-Sable, in bend between two double cottises three lions passant Argent; impaling, Argent, three roses, a crescent for a difference.

Crest.-An eagle displayed. Motto.-suivez raisox.

Lient.-Col., second son of John, 1st Lord Kilmaine, born 1770, mar. 1797 Anne, dau. of John White of J., and died 1855.

Wm. White of Landoveny plantation in St. Anns, in his will dated 1796 , names his late nephew John, eldest son of testator's deceased bro. John. Dorothea Sus ${ }^{a}$, relict of the last, was residing with her six daus. in Grantham.

564. "John Wigglesworth" Arm. (F.M.) (Areher, 116.)

565. "Col. Wridmax. Newstead Abeer, co. Notts" Arm. Originally engraved by Becker for "Burke's Heraldic Illustrations," and afterwards reworked and used as a bookplate. (F., 31,764.)

ArMs.-Azure, on a chevron Ermine, between two eagles displayed and a lion passant Or, three stars; impaling, Gules, between two roses, a bend engraited Erminois, thereon three annulets of the field [PREISIG].

Crest.-Out of a mural crown a demi-lion rampant, in its mouth an axe dropping blood. MotTo.- TENTENDA VIA EST.

The Wildmans made a large fortune out of the management of the plantations of the Beckfords. There are other plates, F. 31,765, 6, 7 and 9.

566. "Gum: Wimimans de Sancte Anne Parochiô in JamaicâA Armigr, W. H. Toms sculp" (F.E.M.)

ArMs.--Gyronny of eight Ermine and Sable, a lion rampant Or.

Not in Fincham.

567. "Gershom Wimumams Inner Temple" Chip. arm. (F.C.)

Arms as above.

Crest.-A talbot Ermine and Or. Motmo.-SPero MeLIora.

568. "John Wilson, Kingston. Jamaica" Pict. The name is given on an open book, which is surrounded by a wreath. (Allen, 948.)

569. "John Yorke Esq". Richarond" Wreath and libbon arm. (F., $32,877$.

Arms.-Argent, a saltire Azure; impaling, Gyronny of eight Or and Sable within a bordure quarterly-quartered Emine and Argent [CAMPBELL].

CREst.-A monkey's head erased.

Of Beverley and Richmond, mar. secondly in 1769 Eliz. Woodstock, dau. of Peter Campbell of Fish River, J. The Jast named died 1817, aged 81. (G.M., 377.)

570. "Rotal Agricultural Societr of Jamaica" Arm. (F.M.)

571. "Union Hati Library Jamatca." Within an oval wreath. (F.C.)

572. "Morant-Bat Circulating Library \& Reading Room D. Wilson \& Co." Large label. (W.E.B.) 
573. "JAs TiRgo Dunx" Festoon arm.

Arus.-Gules, a sword in pale, hilt downwards, between three padlocks.

Crest.-A hand erect couped, holding a key. Мотto.- IrecuM навіта.

Brought from J. in $1874-5$ by Mr. W. F. Lawrence of Cowesfield. Of Kingston, J., merchant, born there 1760 , mar. in 1780 Eliz. Simpson, eldest dau. and coheiress of John Simpson of Bounty Hall, Trelawny, planter. She was born 1762, and died in London 1839. He died at Leamington Spa in 1820.

574. "George Harte" Chip. arm.

Arus.-Argent, a fess Sable, in chief three roses of the field. A crescent for a difference. ĊREST.-A crane's head couped. No Motto.

See ante, I., 297, and II., 122. (F.C.)

\section{¿ttartimítur.}

575. "Governor MImnes." Arm. spade shield. (F., 20,679.)

Arus.-Azure, a chevron between three windmill sails Or; impaling, Azure, a cross moline Argent [BeNTINCK].

CREST.-A garb banded by a fess dancetty Argent, thereon three mullets Sable.

MotTo.-SOTEz SAYs REPROCHE.

Robert Shore Milnes, born 1746, Gov. of M. 1795, Lieut.-Gov. of Lower Canada 1799-1S03, created Bart. 1801, mar. Charlotte Frances, dau. of Captain John Albert Bentinck, and died 1836. See his portrait after Romney in the "Connoisseur," xxvii., 191.

\section{Ploutserrat.}

576. "Herry Dren" Wreath and ribbon al'm. (F., 9428.)

Arus.-Or, a chief indented Sable. CREst.-Out of a coronet a goat's head.

Chief Judge of M., matriculated from St. Marr Hall, Oxf., 1759, aged 17, as son of John Dyer of M., Esq., and died 178s. His father, who was also Chief Judge, died 1781. (F., 9431.) Mark Dyer (of Tortola) is the same plate with name altered.

577. "John Ratel Frye" Chip. arm. (F., 11,452.)

Anus.-Vert, three horses in pale courant, Argent, bridled.

CREST. - A cubit arm, in the hand a scimetar.

Grandson of President Wm. Frye, Sen., born 1744, M. of C. 1768, mar. 1771 Sarah Pott, and died 1799.

578. "Walter S. Morson, M.D. Lizars" Arm. (F., 21,222.) Engraved about 1820. (Fincham.)

Arus.-Per fesse Ermine and Gules, a pale counterchanged, over all a lion salient reguardant.

Crest.-A tion's head erased. London, from Norwich, granted 1723. (Burke's "Armory.")

His second name was Skerrett (probably a descendant of Walter Morson, Chief Justice of M., who died 1804), practised in A., and died 1832, aged 30.

579. "H. L. Dotglas Morsor." (F., 21,221.)

Has the saine Crest and Arms.

MotTo.-FILUS ATQCE FORTIS. 
580. "Ricuard Musgrate" Arm. (F., 21,443.)

Aris.-Azure, six annulets, 3, 2 and 1.

CREST. - Two arms in armour embowed and counter embowed, in the hands an annulet. MOTTO.-SANS CHANGER.

Of the Inner Temple, barrister-at-law, died 1848, aged 57.

581. "Richard SrMs EsqR. 1703." Early arm. (F., 28,763.) F., 28,728 is the above plate reworked and altered to "Symes."

Anis.-Azure, three escrllops in pale.

Crest.-A demi-horse rampant couped.

Of Lewisham, co. Kent, died 1728, aged 72, brother of Lieut. Geo. Syms of M., and of Capt. Henry Syms of A.

582. "Dominick Trant of Dingle, Esq ${ }^{R} "$ Bookpile arm. arms on a' mantle. (F., 29,738.)

AnMs.-Gules, two swords in saltire between four roses.

CREst.-A demi-eagle affrontée couped, with wings expanded.

MotTo.-AQUILA NON CAPIT MUSCAS.

? of M. in 1724, M. of C. 1730 , and died 1762. There were many of the name in the W.I., and difficult to connect.

583. "Robert Turte" Chip. pict.

Ariss.-Quarterly Argent and Gules.

Cnest.-An angel vested Argent, holding in the dexter hand a flaming sword, and the sinister resting on a shield of the arms.

Motto.- alleluia alleldia alieldia.

Born in M. (W.E.B.) ? only son and heir and ex'or 1772 of Nich. Tuite of London. Perhaps of Philadelphia.

584. "Miss Elinora Tutte" Chip. arm. lozenge. (F., 29,940.) (Illustrated in E.L.J., 1x., 100, and ante, 145.)

Arms.--Quarterly Argent and Gules. Motro.-Alleluia.

Robert and Elinora were named 1724 in the will of their father Rob. Tuite of Warrington as W.I. merchant, and of which Sir Jos. Tuite, Bart., was an ex'or. Another of the same names was dau. of Nich. Tuite of London, merchant, who died 1772, aged 66, and mar. before 1753 Tho. Selby of Biddleston, co. Northumberland. The above were all apparently of Tuitestown, co. Westmeath.

585. "N. Whbe Esq ${ }^{\mathrm{Re}}$ 24, Portland Place." Crest. (F., 31,176.)

Crest. - A demi-buck erect, erased.

Nathl. Webb, M.P. Taunton and of Savile Row, died 1785, and his son of the same names was then in the Coldstreams.

586. "Mrs Spencer WeBb." Arm. Arms of Webb with Flight on an inescutcheon. (F., 31,180.)

Anus.- Sable, in bend three escallops. On an inescutcheon: Or, on a chevron Sable, between three pellets each charged with a martlet, a fleur-de-lis between two hares (?) courant.

Of Clifford, co. Somerset.

587. "JонN WeBв 'EsQ" Chip. arm. (F., 31,172.)

Arms of Webb. Crest.-A buck's head erased.

J. Webb, younger bro. of Nathl. Webb, had a son John Spencer Webb of Hackney in 1785 . F.C. has a pictorial Chip. John Webb, Esq., signed "Bache sculpt Birmingham," with the same coat and crest, which may belong to this man. 
5SS. "Jolin SPexcer Colepeper ESQR" Jac. transitional arm.

ArMs.-Argent, a bend engrailed Gules [CoLEPEPER]; impaling, Sable, three escallops Argent bendwise [WEBB].

Crest.-A falcon with wings expanded. MotTo.-J'Espere.

589.- "JoHN Spencer Colepeper EsQR" Jac. transitional arm. The last plate reworked.

Arus.-Single coat of Colepeper.

590. "JoHN SPENCER COLEPEPER ESQ ${ }^{\mathrm{R}} \mathrm{JUN}^{\mathrm{E}}$ " The last with name altered.

I think the Franks' catalogue is wrong as to the Colepeper plates, and I take them to be as abore. Mr. Gambier Howe calls them "Chips," but they are really transitional Jac. to Chip., and he says (incorrectly) that the J. S. C., Jun., married Mary Webbe. The fact of the plate with "Jun" having the single coat makes this the later state, and the appearance of the plates bears this out. (F.C.)

591. "J ${ }^{\circ}$ Spencer Colepeper EsQR" Crest. (F., 6391.)

Crest of Colepeper.

John Spencer Colepeper, eldest son and heir of Wm. C. of Hollingbourne, co. Kent, and nephew and heir of Frances, wife of John, 3rd Lord Colepeper, was for many years Treasurer of the Charterhouse. He mar. 1stly in 1743 Ruth, sister of Robert and Nathaniel Webb of M., who died 1746, and 2ndly in 1752 Mary Webb, sister of another Ruth Webb (ante, I., 43), and died in 1788, leaving an only son and heir John Spencer Colepeper, who was born 18 Dec. 1746, and named in the intail of the estates of his uncle Nath. Webb in 1784.

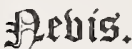

592. "Alexander Hamilton" Plain arm. spade shield with Crest and Motto. (E.L.J., viii., 153, by TV.E.B.)

Born in Nevis 1757, removed to Boston about 1774, drafted the Constitution of the U.S.A., killed in a duel at the age of 47 .

593. "WALter Nisbet" Arm. spade shield. (F., 21,906.)

ARMs.-Argent, three boars' heads erased.

Crest. - A boar's head erased.

MotTo.- $T$ IS Fortibus ARMa.

Of Mount Pleasant, M. of C. 1759, died 1765. His son Walter, born 1745, was living 1793.

594. "Ferdinando John Paris, of the Inner Tejiple, London. Gent." Early Jac. arm., printed in brown. (F., 22,680.)

Arurs.-Gules, a fess wavy Sable between three unicorns' heads couped Or.

Crest.-A sphinx proper.

Col. Edw. Paris was of Nevis 1707. F. J. Paris did much legal work for the Leeward I. 1730-48, and was probably W.I. He was also solicitor to the S.P.G., and agent for Pennsylvania. His will was proved in 1759 . (412, Arran.)

595. "R. Boileau Penibertoy" Arm. (F., 23,167.)

ARMs.-Argent, a chevron between three buckets Sable.

MotTo.- SECUNdis DUBIISQUE RECTUS.

Capt. in . Indian Army, born 1798, died 1840. 
596. "R. C. B. Penberton." Arm. (Illustrated ante, I., 272.)

Arms and Motto. CRes'r.-A boar's head erect, couped Sable.

Major-Gen. R.E., C.B. (retired), born 1834, now living.

597. "John Pinnex, EsQR" Arm. spade shield. (F., 23,654.)

AnMrs.-Quarterly: 1 and 4, Gules, three crescents Or, issuant from each a cross-crosslet fitchée Argent [PINnEY]; 2 and 3, Or, a double-headed eagle displayed [PRETOR].

CREST. - A dexter cubit arm in armour, holding a cross-crosslet fitchée.

Motto.-AMor patris.

He was born Pretor, and took the name of Pinney, High Sheriff of Dorset 1764, President of Nevis 1794, later of Bristol, merchant, and Somerton Erleigh, co. Somerset, where he died 1818.

598. "John Charles Pinney" Crest of Pinney in a garter. (F., 23,654.)

Second son of Chas. Pinney, Mayor of Bristol, and grandson of the above, Vicar of Coleshill, co. Warwick, mar. 1862.

599. "Peter Batllie G. Johnson sc Bristol" Arm. shield in a garter. (F., 1172.)

ArMs-Azure, nine stars, 3, 3, 2 and 1 [BaIllie]; impaling Prnney, quartering Pretor.

Of Dochfour, N.B., and of Bristol, mar. 1797 Eliz., dau. of John Pinney, and died 1812. The Baillies had large interests in the W.I.

600. "Eliz" Ba Buldie" Arm. lozenge in a wreath. (F., 1160.)

Arass.-Batrlite, impaling Pinney.

601. "Frantis Williams Sanders Esq $Q^{R}$ of Lincoln's InN" Arm. (F., 26,049.)

ARMs.-Sable, between three bulls' heads cabossed, a chevron Ermine charged with a rose. CREST. - A demi-bull erased, charged with a rose.

602. "Francis Wilitams Sanders Esq ${ }^{\mathrm{B}}$ of Lincolns Inn, Warwick Sc. 145 Strand." Arm. (F., 26,050.) Engraved about 1820. (Fincham.)

Probably son or grandson of Fra. Sanders, Jun., who mar. 1748 Martha Williams.

603. "J. W. SANDERS" Arm. (F., 26,056.)

Arms and Crest as above.

The Editor found the signature "John Williams Sanders 1768" in a book beneath the bookplate of John Pinney of N. F. 26,057 is a reworked plate.

F. 26,062, anonymous, has the same arms and crest with the addition of the Motto: ESSE QUAM VIDERI.

604. "William Suith" Festoon arm. (F., 27,409.)

ARMs.-Gules, on a chevron Or between three bezants as many crosses pattce fitchée Sable.

CREST.-Out of a coronet a goat's head couped. F. 27,397 has the same arms and crest, but is of later style.

Perhaps of Roundhill plantation, born 1734, and in London 1757.

605. "JА ${ }^{\mathrm{s}}$. Toвis W. Darling" Urn arm. Engraved about 1780. (Fincham.) (Illustrated in E.L.J., ix., 143, and "Antigua," iii., 136.) 
ARus.-Or, three leaves. F. 29,519 is the same plate with Crest, a dove, added. F. $29,51 \mathrm{~S}$ is the same plate, but "Jas" bas been erased and "G" written, evidently by Geo. Tobin, a son, born 1768, Admiral, and died 1838.

Born 1737, removed to Bristol 1783, where he died 1817.

606. "I. Woovley EsQ ${ }^{\mathrm{R}} \quad$ B. Cole sculp." Chip. arm. (F., 32,465.) Engraved about 1750. (Fincham.) Illustrated in "Antigua," iii., 256. F. 32,466 has the engraver's name erased.

ARus.-Sable, a chevron between three owls Argent. CREst.-An owl.

Jolin Woodley was M. of A. 1718, 1724, 1730-1. His son John born 1715, died 1760 .

607. (Viscount Nelsov). Anonymous. Arm., two shields accolé on a hatchment. Not a bookplate. (F., 21,649.)

Arms.-I. Nelson; II. NBLsor with, on an inescuteheon: Barry of six Azure and Argent, three bucks' heads cabossed, on a chief Ermine a lion passant between two pheons [WOOLWARD].

Capt. Nelson mar. 1787 at St. John's, Nevis, Frances Herbert, dau. of Wm. Woolward and widow of Dr. Josiah Nisbett.

\section{马t. (Troir (驲antísh))}

609. "Christopher McEvot, EsQ ${ }^{\mathrm{R}}$ " Pict. arm. (F., 19,194.)

Anurs.-On a chief Azure a demi-lion rising out of a fess Gules; per pale Argent and Ermine, a hand couped Gules in dexter base quarter.

CREST.-A hand couped holding a short sword in bend sinister.

Motro.-Non sine SANGUINE.

Died 1792, aged 72. M.I. at St. Pancras (ante, 127). He and Michael McEvoy were both subscribers in 1790 to Peterkin's "Planting."

609. "Jounnes MoErox" Festoon arm. (F., 19,193.)

Arus.-The chief and hand are Argent. Crest as above. No Motto.

A plate of John McEvoy with arms, crest, and motto as above was illustrated in E.L.J.

610. "MARKOE." Arm.

Removed from St. C. to Philadelphia. (F.M.) The late Dr. Francis Hartman Markoe, Professor of Clinical Surgery of Columbia, N.Y., who died 1912, was of this family.

Wm. Markoe died 1797, aged 34. M.I. in St. Olave's, Jewry. In 1737 Philip M. was Deputy-Gov. and Peter a M. of C. of Anguilla.

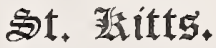

611. "RALPH AdYe M.D" Arm. (F., 199.)

Anus.-Azure, a fess dancetté Or between three cherubs; impaling, Gules, a lion's head erased between three estoiles [EsDAILE].

CREST.-On a mount Vert a stag couchant.

He mar. about 1788 Eliz. Esdaile, and died 1804. (Ante, II., 242.) 
612. "Willett Lawrence Adye" Seal arm. (F., 200.)

Arus.-Adye as above. Crest.-The stag is collared and chained.

MotTo.-NIL DISPERANDUM.

Of Merly House, co. Dorset, born 1818, died 1878.

613. "Winifreda Watson-Arustrong 1897" Piet. arm. (Illustrated in E.L.J., xi., 81.)

Arms.-Whtson quartering Armstrong, impaling Adye as above.

614. "JaMes Akers EsQR" Festoon arm.

Arms.-Gules, three escallops Argent. Crest and Motto as iu F. 263. (F.C.)

He mar. before 1766 Jane Dupuy, who died in 1.789, aged 65. He and J. A., Jun., were both parties to a close roll of 1790 .

615. "Endund Fieming Akers" Festoon arm. (F., 263.)

Arus.-Gules, three escallop shells Or.

CREST.-An arm vested bendy Azure and Or, in the hand a pennon bendy of the same charged with a Saracen's head proper between eight crosses counterchanged. Motto.-Je tive EN ESPeratce.

Nephew, I think, of the preceding, of Berrymead Priory, Acton, co. Midd., mar. 1stly Frances Rawlins, and 2ndly, in 1816, Cath. Dewhirst, and died 1821.

616. "E. F. A" Crest, Cypher, and Motto. (F., 264.)

617. (AKERs). Festoon arm. (F., 265.)

Anus.-Single coat, Crest, and Motto as above, surrounded by an oval edge of laurel leaves. Beneath is written: "ARETAS Akers."

618. "H.S. Hardtanan Berkeley" Arm. ("Baker;" F., 2318.)

Arus.-Quarterly: 1 and 4, Gules, a chevron between ten erosses pattée Argent, six above and four below, with a crescent for difference [BERKELEY]; 2, Sable, a demi-man in armour affrontée, couped across the thighs, in his dexter hand a pick or axe bendwise [HarDTMaN]; 3, Gules, on a bend sinister wary Or, between two crescents of the second, three mullets of six points of the first.

Cres'rs.-1, A mitre charged with a chevron and ten crosses pattée Argent; 2, Out of a coronet a man in armour affirontée, couped across the thighs, between two wings, each charged with a crescent and a bar.

Mottoes.-1. Above: Ubi anior ibi fides. 2. Below : Died avec nous.

Henry Spencer H. Berkeley, born at St. Kitts 1851, Solicitor.Gen. of the Leeward I. 1878-83, Chief Justice of Fiji 1889-1902, knighted 1896, AttorneyGen. of Hongkong 1902-6, mar. 1878 Kath., dau. of Fred. Cassin of Antigua. The above arms were taken from family seals since lost. The third coat is probably a Hardtman one. Sir Henry thinks the plate was by Culleton.

619. "Patrick Blake. Foster Sculp Fetter Lane" Chip. arm. (F., 2760.) Eugraved about 1760 . (Fincham.)

ARMS.-Argent, a fiet Gules. Crest.-A mountain cat passant guardant.

Motto.-Confido in probitate.

620. "Patrick BlakE" The last plate reworked. (F., 2761. Illustrated in E.L.J., x., 6.)

Aruss.-Blate, impaling Argent, on a bend Sable three chess-rooks [BUnbery]. Crest and Motto of Blake.

Of Langham Hall, co. Suffolk, created a Baronet 1772, mar. Annabella Bunbury, divorced 1778, and died 1784 .

621. "Henry Brouncker Esq" Jac. arm. shield on a mantle. (F., 3917.) ArMis.-Argent, six plates, 3,2 , and 1 , a chief embattled Sable.

CREST.-An arm in armour embowed, in the hand a sword.

Of Ireland. (Burke's "Armory.") 
622. "Henti Brodncher Esiq ${ }^{R}$. Boveridge." A modeln impression of the last plate with altered inscriptiou. (F., 3948.)

H. Brouncker, Sen., mal. 1stly Eliz., and 2ndly in 1761 Susammah Fenilleteau, and died 1773, leaviug a son H. B., who purchased Boveridge in Cranborne, co. Dorset, in 1788, and died bachelor 1825, aged 58. He used the arms as in F. $39 \pm 7$, with certain additions for a difference.

623. "Mary Brodxckeтr." Arm. loz. (F., 3949.)

Arms as in F. 3947, but with ogresses.

Dau. of H. Brouncker, Sen., born 1766, mar. 1789 Adm. the Hon. Wm. Finch.

624. "JoHN SMrth Budgen, EsQ (Hughes Fecit)" Wreath and ribbon arm. (F., 4269.) Not dated in Fincham.

Anurs.-Sable, a vyvern; impaling, Ermine, a millrind Sable [MILLs].

Crest. $-A$ woyzern.

Only son and heir of Tho. Budgen, M.P. Snrrey, by Penelope, dau. of Dan. Smith, Dep.-Gov. of Nevis. Of Dorking, co. Surrey, b. 17\$1, mar. 1764 Lucretia, 2nd dau. of Matthew Mills, Jun., and died 1805.

625. "WILliaM ColHods, EsQR." Festoon arm., two spade shields accolé. (F., 6406. Illustrated in E.L.J., ix., 81.)

Arus on the first shield: Argent, a saltire engrailed Sable [CoLHowr]. On the second shield: Gules, two cheorons Ermine between three eagles displayed or [Parsons]. Crest.-A stag's head couped.

W $\mathrm{m}$. II Dowall Colhoun, only son of Rob. C., Treasurer of St. Kitts, was in 1773 of Wretham, co. Norfolk, and living in 1793. Nath. Parson of St. K. was uncle of the former. In $1678 \mathrm{a} \mathrm{Wm}$. C. was M. of A.

626. Nicholas Crooke (Gregory sc.) Arm. Crook with Jolly on an escutcheon. (F., 7430.) Engraved about 1810. (Fincham.)

Arus.-Argent, on a bend Gules three roses. On an inescutcheon : Argent, an ark in the water, a dove standing thereon, all between three gilly-flowers. [Joxux of Scotland]. Crest.-A raven proper. Motro.-toral a moRT.

Of St. John's, Cabbesterre, 1753; his son of the like names was bapt. 1721. John Jolly died at St. K. in 1782, aged 21.

627. "Samuel Crooke of the Minden Temple." Chip.

Arms as above, quartering: Sable, a chevron Argent between three owls. (F.C.) The latter coat is certainly "Woodley" of St. K.

? M. of C. of St. K., of Brook Street 1764, died 1772.

628. "Daniet Cunrngham, EsQR." Chip. arm. (F., 7606.)

Arurs.-Quarterly : 1 and 4, Argent, a shake fork Sable [ConYngHAu]; 2 and 3, Or, a fess checky Azure and Argent [STEWART]; impaling, Or, three crescents, on a canton Sable a coronet [HoDGES]. CREST. - A unicorn's head couped.

Above is the Motto.- VIRTUTE ET L'GOIT in the first state, and L'GoIT replaced by LABORE in the second state. Below is the Motto.-VIRTUTE ET LABORE VERUM AMICUM COLE. F. 7607 is a smaller plate, with below only VERUM AMICUM COLE.

Son of Capt. Robert Cunyngham of St. Kitts, mar. Eliz. . . . ., and died 1776. (Ante, I., 101.)

629. $\operatorname{RoB}^{\mathrm{T}}$ Cunyngham EsQ ${ }^{\mathrm{B}}$. Late Jac. arm. (F.C.)

Arus.-Conymgham quartering Stewart. Mottoes as in F. 7607.

Probably the brother of Daniel.

630. "JNo KNight EsQ ${ }^{\mathrm{R}} "$ Chip. arm. (F.C.)

ARrs.-Argent, three pallets Gules, on a canton of the second a spur with the rowel downwards, leathered Or, within a bordure engrailed Azure; impaling 
Cuningham, quartering STEwaRT as in F. 7606, within a bordure engrailed Gules.

CREST.--On a spur lying fessways Or, an eagle erect with wings expanded.

Of Cookley, co. Worc., mar. 1765 Henrietta Cuningham of St. Kitts, who died 1802. (Ante, III., 46.)

631. "Charles Pearce." Chip. arm. (F., 23,007, and F.C.)

Arus.-Argent, Guttée de sang, a chief nebulée Gules; impaling Cunivghar, quartering Stewant, as in preceding. Crest.-A demi-stag couped, collared.

Of London, merchant, mar. Eliz. Philadelphia Cuningham of St. Kitts.

632. "Jayes Dewar of Vogrie." Jac. (J.M.)

633. "James Dewar of Vogry, EsqR" Chip. arm. (F., 8570.)

Anus.-Or, a chief Azure.

This plate has been altered to "James C. Dewar of Vogry." (F.C.)

634. "David Dewar, Esq ${ }^{\mathrm{R}}$. Enham, Hants" Crest. (F., 8569.)

Crest.-An anchor cabled. Mot'so.-DUy spiro spero.

Second son and heir of Geo. Dewar of St. Kitts (who was named in the entail of the Togrie estate in 1772), mar. 1787 Penelope Susanna Mathew, and died 1794, aged 4.6 .

635. "John DewaR" Crest. (F., 8573.)

Crest.-An anchor. Motto.-As F. 8569.

Eldest son of Geo. Dewar, apparently disinherited, living 1785.

636. "I. E. DEwıR" Arm. spade shield (? Chip.). (F., 8572.)

Anus. - A ship on the sea, on a chief Azure three boars' heads erased.

Crest.-As in F. 8569.

637. "Eliz. ST Leger Douglas" Chip. arm. lozenge. (F., 8906.)

Anus. - Argent, a human heart proper, crowned, on a chief Azure three mullets of the first.

Dau. of Jas. Geo. Douglas by Mary Payne his wife, mar. 1769 John Willett.

638. "JosepH Estridge. (Cook \& Johnson sc.)" Arm. (F., 9969.) Engraved about 1850 (Fincham).

Arus.- Ermine, on a bend engrailed Azure three ostriches' heads erased.

Crest.-An ostrich with wings expanded. Motro.-Deus tutamen.

Sixtb son of Jos. Estridge of Carshalton Lodge, co. Surrey, born 1811, Lieut.Col. Bombay Engineers, and died 1890.

639. "Eliza Estridge. (T. Culleton 2 Long Acre, London)" Arm. lozenge. (F., 9968.) Not dated in Fincham.

Arms as in F. 9969.

Only child of John Estridge by Eliz. Parson his wife, born 1794, died 1868.

640. (Fencos). Anonymous. Chip. arm.

ARMs.-Quarterly: 1 and 4, Gules, three chevrons Argent; 2, Sable, a chevron between three spear-heads Argent, embrued at the points Gules; 3, Azure, a chevron between three crescents Argent. These arms are painted on the tablet in Bath Abbey (only adding on an escutcheon of pretence, Argent, a cross between four fleurs-de-dis Sable for Fenton) in memory of Jane, wife of John Roberts, and only child of Wm. Fenton of St. Kitts by Jane his wife, dau. of Wm. Cleaver. She died 1806, aged 65. (Note by Mr. A. J. Jewers in the E.L.J. See ante, I., 79.) 
64l. "Stricklaxd Freemax Esq and ribbon arm. (F., 11,346.)

Arus. - Purpure, three lozenges Or; impaling, Gules, a chevron Or between three crosses pattee, on a canton Ermine a stag's head erased [STRICKLAND].

Crest.-A demi-lion rampant, couped, charged with a lozenge Argent.

MotTo.- Libertas et Natale solum.

IIar. 1781 his cousin Eliz., dau. of Sir Geo. Strickland of Boynton, Bart., and succeeded in 1782 his uncle Sambrooke Freeman of Fawley, M.P.

642. "Strickland Freemay. Fawley Court, Buckinghamsmire." Arm. (F., 11,3 4 .) Freeman impaling Strickland as above, but a different design.

643. W. P. Wildiams Freenad EsQ (Warwick sc. 145 Strand). Arm. (F., 11,354.) Not dated in Fincham.

Arus.-Quarterly: 1 and 4, Freemar, the field Azure; 2 and 3, Gules, a wolf reguardant, issuant from a cave on the sinister side [WILIILMs].

Crests.- - 1, Freejiar, Gules; 2, $A$ lion rampant, crowncd.

A note written across the plate records that the book was given to a friend in the year 1835. Wm. Peere W. Freeman of Fawley Court, born 1782, mar. 1811 Frances Dorothea Blencowe, and died 1830. His father of the same names, born 17t1, who assumed in 1822 the arms of Freeman, and died 18:32, may have also been the owner of above plate.

644. "Sir William Payne Gallwex, Bart. M.P." Arm. (F., 11,598.)

AnMs.-Quarterly : 1 and 4, Per fess Or and Gules, in chief an eagle displayed Sable, in base a castle [GALLwET]; 2 and 3, Gules, a fess between two lions passant Argent [PAINE]; on an inescutcheon, Quarterly: 1 and 4, Argent, a lion rampant Sable, on a chief of the second three roses [RussELL]; 2 and 3, Azure, a dolphin naiant embowed, on a chief Or two saltires Gules [FRANKLAND]. Badge of Ulster.

Crests. - $1, A$ cat passant guardant; $2, A$ lion's gamb couped, holding a broken spear-head. MOTTO.-viNCIT OMNIA veritas.

Born 1807, succeeded as 2nd Bart. 1831, M.P. 1851, mar. 1847 Emily Anne, third dau. and coheiress of Sir Robert Frankland Rnssell, Bart., and died 1 s81.

645. "Stephen Parne Galway, EsQ ${ }^{\mathrm{R}}$ " Arm. spade shield. (F., 11,611.)

Anus.-Gules, per fess Azure and Gules, \&c., quartering PArNe. Crest of Galway.

Of Tofts Hall, co. Norfolk, uncle of the preceding, born 1749, assumed the surname of Gallwey 1762, mar. Mary de Lancey and died 1812.

646. "John Garnett of $\mathrm{S}^{\mathrm{T}}$ Christopher" Chip. pict. (W.E.B.)

A subscriber 1790 to Peterkin's "Planting," Registrar and M. of. C. 1821. There was also a J. G. who was M. of C. 1702.

647. "Johi Garnett" Chip. (Allen, 298.)

ARMs.-Gules, a lion rampant within a bordure Or. (F.C.)

648. "William Payne Georges" Chip. arm. (F., 11,788.)

Arus.-Ermine, on a saltire a leopard's face cabossed.

CREST. $-A$ wild boar statant.

Chief Justice of St. Kitts 1780-1799, mar. Eliz. Payne, sister of Lord Lavington, and died about 180t. He had a son and grandson of the same names.

649. "JA A $^{\mathrm{s}}$ GInger M.D. (Signed) R. $M$. ." (R. Mountaine). Chip. arm. Not in Fincham. I think my copy of this plate is the only one known. (F.C.)

ARMs.-Azure, a crescent between two mullets in pale Or.

CRest.-A hand holding a bow. Motto.-mente et Manu. 
Born 1721, army surgeon, M.D. Ed. 1753, writer, L.R.C.P. 1758, travelled with young Mr. Bourryan of St. Kitts, practised there 1759, mar. there, wrote a poem "The Sugar Cane" and Essay on W. I. Diseases, and died 16 Dec. 1766, in his 46th year. (Munk, II., 219.)

650. "Bertie Greatheed." Arm. spade shield. (F., 12,620.)

Anas.-Azure, a saltire Or between four fleurs-de-lis. CREST.-A fleur-de-lis.

Only surviving child of Sam. G. of Guy's Cliff, co. Warwick, M.P. for Coventry, by Lady Mary Bertie, eldest dau. of the 3rd Duke of Aucaster. He came of age April 1782.

651. "R. W. Greatheed EsQR" In pictorial Chip. frame.

Crest.--d fleur-de-lys. (F.C.)

652. "Isabella Hammton." Arm. shield on clouds. (F., 13,471.)

Arms.-Quarterly: 1 and 4, Gules, three mullets pierced; 2 and 3, Argent, a ship [ARRAN].

CREST.-Out of a ducal coronet an oak tree penetrated transversely through trunk by a frame saw. MotToEs.-THROUGH. NEC TIMEO NEC SPERNO.

Dau. of 5 th Earl of Buchan, mar. $1770 \mathrm{Wm}$. Leslie H. attorney-gen. of the Leeward I., who died 1780 . Her portrait after Romney has been engraved.

653. "G. C. Julius" Arm. spade shield. (F., 16,771.)

ARMs.-Argent, a fess Azure between three stars.

Crest. - A star. Motro.-virtute et industria floresco.

Geo. Cha. Julius of the Old Palace, Richmond, M.D., mar. 1795 Isabella Maria, dau. of the Rev. Jonathan Gilder, and died 1866, aged 91 . He had 1, Geo. Cha. Julius, and 2, Fred. Gilder Julius, born 1811, who mar. Ellen Smith, and died 1886. (Lieut.-Col. H. W. Pook.)

654. "George C. Julius" Arm. (F.C.)

Arms of Julius impaling Argent, a fess Sable between three martlets.

Crest and Motto of Julius.

655. "Frederick G. JULIUS" Arm.

Arms.-Julius, with Smith on an inescutcheon. (F., 16,770.)

Arms.-As above, but the stars Gules, and on an escutcheon, Or, a chevron cotised between three demi-griffins Sable [SмrтH]. Crest and Motto of Julius.

656. "ANT $\mathrm{HART}^{\mathrm{X}} \mathrm{EsQ}^{\mathrm{R}}$ " Arm. (F., 13,931.)

Anus.- Sable, a bend Or letween three fleurs-de-lis.

CREST.-A stag trippant.

B. 1757 at St. K., Lord Chancellor of Ireland and knighted 1827, mar. Martha Jefferson, and died 1831. (D.N.B.)

657. "JoHN HAR'T" Chip. pictorial.

The same Crest and Arms, but the bend Argent; impaling, Azure, on a fess between three crosses-crosslet placed saltireways Argent as neany crows [? CroziER]. (F.C.)

658. "Losack" Anonymous. Arm. From a photograph of a bookplate (?).

Arms.-Azure, a double-headed eagle on a chief per pale Argent and Gules, on the dexter side three crescents, and on the sinister three mullets.

Crest. $-A$ double-headed eagle over a Count's coronet.

Mot'To.-sans crainte.

Used by Admiral Geo. Losack (eldest son of Richard Hawkshaw, late President of St. K.) who died 1829. 
659. "Wilim Mcdowall of Castlesemple EsQ ${ }^{R}$ "Jac.arm. supporters. (F., 19,183; dllen, 535.)

AnMs.- - dzure, a lion rampant crowned with an antique croun.

Crest.--A hand erased holding a dagger erect. Supporters: Two lions rampant gorged with a coronet and cach holding in its dexter paw a dagger.

MIOTTO.-TINCERE VEI MORI.

Boln 1700 and by his wife Eliz. bad a son Wm., M.P., who died bach. 1810. One with the same names was M. of Council of St. K. I721 (Arms in Senex's Atlas) and nearly related to the above. Several of the family were inrolved in the banliruptey of Alex. Houstoun \& Co., W.I. merchants, of which firm they were partners.

660. "Richard Maítadsd 1769" Arm. spade shieid pendent from a ribbon in an ornamental oval frame. (F., 19,519.)

Arsis.- The royal coat of Scotland. CREsT.-A lion's head erased.

MIOTTO.-PAIX ET PEU.

of L. and Woodford, co. Essex, W.I. merchant, partner with Messrs. Boddington, and died 1775. His only son Thomas mar. Jane Mathew of St. K.

661. "Wildiam Manning" Arm. spade shield. (F., 19,658.)

ARMs.-Quarterly Azure and Gules, a cross flory between four trefoils Argent. Crest.-Out of a coronet an eagle's head between two ostrich feathers.

Born 1729, died 1791. (Ante, I., 24.2.)

662. " William Manning Jun ${ }^{R}$ " The same plate but inscription altered. (F., 19,659.)

Born 1763 , died 1835 . F. 19,653 and F. 19,649 also relate to this family.

663. "Thomas Austen" Arm. (F., 9S5.)

A Riss.-Quarterly: 1 and 4, Or, a cherron Gules between three lions' gambs erect Sable [Austen]; 2 and 3, Argent, a chevron between three mullets Gules, impaling Mannisg. Crest.-On a mural crown a stag sejant.

Col. Austen of Kippington Park, co. Kent, M.P., mar. 1826 Caroline Cath. Manning, who died 1894, aged 93.

664. "Benjamin Vaughar" Arm. spade shield. (F., 30.260.)

A RMs.- Sable, a chevron Argent between three child's heads couped at shoulders, with a serpent around the neck [VגUGHAN]; impaling, Gules, a cross flory between four 3-foils [MarNixg].

CREST.-A like head. MotTo.-PRUDENTER ét simpliciter.

Born $175 \mathrm{l}$ in J., later a partner with $\mathrm{Wm}$. Mamning, Junr., of L., whose sister Sarah he mar. in 1781, and died 1835 in his 85th year. ("Gent. Mag." $1836,415$.

665. "William Mathew Esq" Jac. arm. (F., 19,9S0.)

A Rus.- Quarterly: 1 and 4, Sable, a crane within a bordure Argent [Starkie]; 2 and 3, Argent, two stars in fess [Van Leemputr]. On an inescutcheon: Sable, on a fess Argent a lion passant between three garbs [HILL]; impaling, Quarterly: 1 and 4, Gules, on a chevron Or three crosses pattée fitchée Sable, between three roundles [SMITH]; 2 and 3, Gules, three men's heads couped affontée [WILLIAMs].

Governor of the Leeward I. 1732 till his deatl 1752, nar. 1stly in 1707-S Anu, dau. and heiress of Col. Tho. Hill, Dep.-Gor. of St. K., who died 1715 ; 2ndly Ann, dau. of Daniel Smith, Dep.-Gov, of Nevis, who died 1730 ("N. and Q.," 8th S., II., 188); and 3rdly in 1731 Margaret, dau. of Isaac Garnier.

666. "IsadC Mathew J. Kirk sculp Pauls Church Ird." Chip. arm. Engraved about 1760. (Fincham.)

Arms of Mathew, quartering VAN Leemputr. No Crest nor Motto. (F.C.) 
Only son of Gov. Wm. Mathew by his third wife Margaret Garnier. Bap: 1734, will p. 1761.

667. Daniel M M'THEW Chip. pict. arm. (F., 19,969. Illustrated in E.L.J., xviii., 84, bv F.C.) No tinctures.

Arms.-Quarterly: 1 and 4, Argent, a stork; 2 and 3, TAN Leempet. An earlier state has on an inescutcheon .... on a chevron betueen three bezants as many crosses formée [SMIrH]. (F.C.)

His first wife was Penelope, only child and heiress of $\mathrm{Wm}$. Smith. She was mar. 1736, separated 1742, and divorced 1745 . 369.)

668. "Daniel Mathew" Chip. arm. (F., 19,970. Illustrated ante, I.,

Arms.--Quarterly : 1 and 4, Mathew ; 2 and 3, VAN Leemfett, impaling Bram. Crest.-A stork. Motto.- æquam servare mentem.

He mar. 1750 Mary Byam as his second wife, and died 1777. In the British Museum in Case 73 is an oriental plate with the above arms on it. It is of the Ch'ien Lung period, 1736-1795.

669. Daniel Bram Mathew Festoon arm. (F., 19,971.)

ArMs.-Quarterly: 1 and 4, Mathew ; 2 and 3, VAN LeempdtT; impaling, 1 and 4, Argent, a fess Azure, in chief three torteaux [DER1sa]; 2 and 3, Argent, a saltire Sable [DERING].

Of Felix Hall, co. Essex, mar. 1784 Eliz. Dering, and died 1838, aged 82.

670. "Daniet Dering Mathew Carus College, Cambridge." Pict. arm. (F., 19,972.)

Arms of Matthew but the field Sable, quartering Vax Leenpet. Motto.

Only son of the preceding, died s.p. 1856. F.C.)

671. "Edward Mathew EsQ ${ }^{\mathrm{F}}$ " Arm. (Illustrated in E.L.J., xviii., 85, by

Arns.-Matthew quartering VAN LeEmput, impaling Bertie.

Born 1728, General, Governor of Grenada 1783, mar. 1743 Lady Jane Bertie, third dau. of Peregrine, 2nd Duke of Ancaster, and died 1805. 146.)

672. (Mathew). Anonymous. Arm. (Illustrated in E.L.J., xriii., 125,

The same arms as above, with a palm tree, two cannons and balls surrounding the shield. Motro.-PRo Rege LEGE GREGE.

This little plate was probably designed for the preceding when he held command in the W.I.

673. "Captain George Mathew, Coldostream Guards" Arm. (F., 19,975.)

The same shield as in Burke's " Heraldic Illustrations."

Among the quarterings are Smith and Williams.

Younger brother of Daniel Byam Mathew, born 1760, of Fabians, co. Essex, mar. Euphemia Hamilton of 'Tobago, and died 1846.

674. "Willtali Mathew EsQ ${ }^{\mathrm{B}}$ " Wreath and ribbon arm. (F., 19,9S1.)

Aruss.-Quarterly: 1 and 4, Starkie; 2 and 3, VAN Leemputt, label of three points in second quarter, impaling Argent, in pale three lions passant Gules [Brogrdve]. Crest of Mathew.

Of Baddow, co. Essex, and of Antigua, mar. 1754 Eliz., dau. and heiress of Wm. Brograve of Scarning, co. Norfolk, and died 1764.

675. (Mathew). Anonymous. Arm. supporters. (F., 19,982.)

Arus.-Quarterly : 1 and 4, StarKie; 2, VAN LeEmputt ; 3, Gules, on a 
chevron Argent three crosses-crosslet between three bezants. On an inescutcheon : Argent, a fess Gules between three goats [HANDLEX].

Crests.-1. Mathew; 2. Out of a coronet an eagle's head. Supporters: Two griffins segreant and collared. Motto. Another plate. Arm. (F., 19,983.) Sir George Benvenuto Buckley Mathew, K.C.M.G., C.B., M.P., mar. 2ndly in $18 \pm 9$ Rosina Adelaide Handley, dau. of Joseph Chas H., Provost Marshal of Turks Island, and died 1879.

676. "John Conyers EsqR. Copt Hall, Essex. H. Gravelot inv. et s." Library interior pict. arm. (F., 6669.) Engraved about the year 1760 and illustrated in Fincham.

Anus.-Azure, a maunch Or, over all a bendlet gobony Ermine and Gules.

He succeeded his father 1742, mar. 2ndly in 1747 Lady Henrietta Fermor, and had an elder son John, born 1748, who mar. 1773 Julia Cath., only dau. of Wm. Wathew of Antigua, and died 1818.

677. "JAMes MrLLiken EsQ ${ }^{\mathrm{R}}$ of Mrulrken" Jac. arm. Also a smaller plate. (F., 20,624.)

Anus. - Argent, two bars wavy Azure, issuant from the top bar three demi-lions rampant, crowned Gules.

CREsT.- $A$ demi-lion rampant crowned, in dexter paw a sword.

MotTo.-REGARDE BIEN.

Major Jas. Milliken was a M. of Council of St. K. 1710, and died before 1720, leaving a son Jas. He was probably related to the above.

678. (Milus). Anonymous. Chip. arm. A reversed impression, not a bookplate. (F., 20,661.)

Arus.-Mitus impaling SodLegre, as in F. 20,639.

Crest with coronet. Motto.

Mathew Mills, Jun., mar. 1743 Cornelia Soulegre, elder dau. and coheiress of Col. Peter S. of St. Kitts, and was knighted 1752.

679. "Peter Matw" Mruls Esq" Chip. arm. (F., 20,647. Illustrated ante, 49.)

Anus.-Quarterly: 1 and 4, Milus ; 2 and 3, Sovlegre, impaling: 1 and 4, Gules, three 5-foils Ermine [HAmition]; 2 and 3, Argent, a three-masted ship [ARRAN]. Crest of Mills without coronet.

680. "Peter MaTW Mrlus Esq ${ }^{R}$ " (printed in red). Arm. spade shield. (F., 20,648.) Arms, Crest (no coronet), and Motto.

Only son and heir of Mathew Mills and Cornelia. Born 1743-4, of Twickenham, mar. Cath. Hamilton, and died 1792. Father of Geo. Galwey M. and of Peter Mathew M., Jun.

681. "Geonge Galwex Mrlus EsQ ${ }^{\text {R." }}$ Arm. spade shield. (F., 20,639.)

ArMs.-Quarterly: 1 and 4, Ermine, a mill-rind Sable [MTLus]; 2 and 3, Argent, three trees fessways, on a chief Gules three crescents between two mullets Or [Soulegre]. On an inescutcheon: Vert, a lion rampant Or [FARRELL].

Crest.-Out of a coronet a lion rampant Or.

MOTTO.-HONOR VIRTUTIS PRETIUM.

M. of Council 1800, M.P. Wallingford, friend of the Prince Regent. The Farrells were of Montserrat. The above arms of Myll are recorded in the Visitation of co. Glouc.

682. "George Galwex Mrlus EsQR." A smaller plate. (F., 20,640.) On the inescutcheon the lion is Gules. The Crest is also Gules.

683. "Thomas Milus" Festoon arm. (F., 20,656.)

Arms and Crest (without coronet) of Mills. 
684. "Paitfield Milis. InNer Temple." Arm. (F., 20,646.)

Arms and Crest of Mills.

Born 1816, Chief Justice of Nevis, where he died of cholera 1854.

685. "Arthur. Willtan English" Arm.

Arms of English with, on an inescutchecn, Mrtus quartering Paitfield.

Of Welsthorpe manor, co. Line., mar. 1845 Mary Ollyffe, dau. of Paitfield Mills of Clayhill Enfield. (F., 9898.)

686. "JeNNETT PAYNe ORToN" Chip. lozenge arm.

ARus.-Purpure, betucen three castles as many fleurs-de-lis, the centre one inverted, debruised of a fess Argcnt. (F.C.)

In 1753 Miss Orton owned a plantation in the parish of St. Thomas and another in the parish of St. Ann.

687. "Brooke Thylon OtTler" Festoon arm. Very rough work.

A RMs.-Argent, on a bend Azure three garbs. CREST.-A garb. (F.C.)

688. "Brook T. Otтles" Arm. (F., 22,461.)

Aruss.-Per bend Or and Argent, on a bend nebuly Azure three garbs between two crosses-crosslet Azure.

CREST.-In front of a garb three arrows, two in saltire, one in pale.

MotTo.-DAT DEUS INCREMENTUM.

Born 1774, of Tallaght, co. Dublin, Commissioner of Mlilitary Accounts, Ireland, mar. Isabella Maria Brown, and was living 1818.

6S9. "Sir Richard Ottuey" Printed label. (F., 22.462.) 184.5 .

Born 1782 at St. Vincent, Chief Justice of Grenada 1814, knighted 1820, died

690. "Frederick Wollastor LLB" Chip. arm. (F., 32,338.)

Arms.-Quarterly: 1 and 4, Argent, three mullets Sable, pierced; 2 and 3, Azure, on a chevron Argent three cinquefoits Gules between as many swans Argent, crescent for difference; impaling, Argent, on a bend Azure three oat sheaves Or [OTTLET].

CREST.-Out of a mural crown a demi-griffin segreant holding a mullet pierced sable. Motto.-NE QUID FALSI.

Third son of Wm. Wollaston of Finborongh, co. Suffolk, born 1735, mar. 2ndly Priscilla, dau, of D. Ottley of St. K.

691. "John Parson" Festoon arm. (F., 22,817.)

Anus. - Gules, two chevrons Ermine between three eagles displayed [Parson]; on an inescutcheon: Azure, a chevron between three muilets Or [CHETwrND].

Third son of Edward Parson of Little Parndon, co. Essex and St. K., mar. 1774 Isabella, dan. and heiress of the Hon. Wm. Richard Chetwynd, eldest son of John, 2nd Viscount Chetwynd, who died v.p. 1765.

692. (Johi Parsox). Anonymous. Arm. (F., 22,818.)

Arms as above.

693. "EdwARd Parsons EsQR" Festoon arm. (F., 22,821.)

A rus.- - Single coat of Parson, as in F. 22,818.

Crest.-A leopard's head surmounted by an eagle's leg erased. 97.)

694. "Ralph Parne EsQ" Chip. arin. (F., 22,964. Illustrated ante, II.,

Andrs.-Gules, a fesse between two lions passant Argent.

CRest.- A lion's jamb erect, erased Argent, holding a titting spear broken, Gules. 
Ralph Payne, Chief Justice of St. C., died about Jan. 1763, and his son of the same names was born about 1738, Speaker of St. C., later M.P., K.B. and Grov. of Leerard I. 1771-6, created Baron Lavington 1795, a second time Grov. 1799 till his death in 1807.

695. "Joseph Webster. Allen sct. Birmm." Arın. (F., 31,207.) Engraved about 1820. (Fincham.)

Anus.-Azure, five swans close in cross between four annulets Or, impaling Parne. Crest.-A swan's head erased, in the beak an anmulet Or.

Motro.-Carpe DIEM.

Of Penns, co. Warwick, mar. Maria Mary, eldest dan. of Sir Peter Payne of Blunham, co. Bedford (Bart.?). She died 18 48 , aged 56.

696. "L L Colonel P. Phipes" Arm. (F., 23,554.)

Arurs.-Sable, a trefoil between eight mullets Argent; impaling, Gules, three pheons, on a chief $\mathrm{O}_{i}$ a bar nebuly of the second [AnNoLD].

Crest.-A lion's gamb erect holding a trefoil. MotTo.-virtute Qujes.

697. ( I $^{T}$ CoL. P. P.) Arm. Single coat of Phipps. Plate rather scarce. (H.R.P.)

Pownoll Phipps, born 1780, Major E.I.C.S. 1821, mar. 2ndly, after 1812, Sophia Matilda, only dau. of General Benedict Arnold of Conn., U.S.A., and died 1858. She died 1828. (See his Life, published in 1894.)

698. "Roberdead" Festoon arm. (F., 25,130.)

Anus. - Sable, a chevron Or between two annulets in fess and a tower in base, on a chief Argent a cross-crosslet Gules.

CREST.-A demi-greyhound erect couped reguardant, around its neck a cloth collar Sable with a cross Argent on its end. MOTTO.-NE CEDE MALIs.

Below are palm leaves. Of a St. K. family. (F.M.)

Daniel Robertan owned a plantation in Trinity, Palmetto Point, in 1753. John Peter Roberdeau, formerly of Bath, died at Chelsea in 1815. I., 1.)

699. "Charles Spoorer EsQ." Chip. arm. (F., 27,745. Illustrated ante,

ARus.-Azure, a boar's head erect erased Or, from the neck three drops of blood; impaling, Argent, on a chevron Gules, between three bugle horns stringed Sable, as many crosses-crosslett Or [BणRT]. Motro.-IMITARI QUEM colis.

Of Harley Street, mar. 2ndly Mary Burt, and died 1790.

700. "HEnRy WARD Townlex Ashby sc. Russel Ct." Wreath and ribbon arm. (F., 29,659.) Engraved about 1770. (Fincham.)

ARMs.-Or, on a fess a mullet of the first, in chief three mullets [TownLEY]; impaling, Argent, a chevron Or between three owls Sable. CREsT.-A falcon.

In 1753 James Ward, Esq., owned a plantation in the parish of St. Mary Cayonne. Townley Ward was in 1793 party to deeds of St. Kitts. (Ante, I., 212.)

701. "ANтhoNy WHarton" Chip. arm.

Arus.-Sable, a maunch Argent within a bordure Or charged with six pairs of lions' paws saltireways, erased Gules.

Crest. - A bull's head couped Argent, gorged with a coronet. (F.C.)

Anthony Wharton of St. Kitts was dead in 1759, leaving a younger son of the same names. (See ante, I., 78.)

"Thomas Wharton" Chip. arm. Has the same arms and crest. (F.C.)

702. "Thos Lucas Wheeler" Arm. spade shield. (F., 31,448.)

Arus.-Argent, a fess Gules between six annulets [LocAs]. 
CREST.-Out of a coronet a wyvern's head.

Capt. in 100th Reg., heir of Tho. Lucas of St. K., and Lee, co. Kent, who died 1784; of New Bond Street, died 1792.

703. "Henry Ralph Wiflett." Arm. (F., 31,840.)

Arurs.-Quarrerly: 1 and 4 , Argent, three bars gemelles, and in chief as many lions rampant Salle; 2 and 3, Gules, a fess between two lions passant Argent [PAYNE]. CreST.-Out of a coronet a moorcock with wings expanded.

MotTo.--SPERAT INFESTIS MEETUIT SECUNDIS.

Born 1786, of Merly, co. Dorset, died bachelor 1857. (Ante, II., 242.)

704. (W illett). Mutilated. Crest and Arms of Willett. (F., 31,813.)

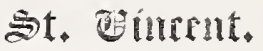

705. "Malachy Corxon" Lyon's book. Chip. arm. (F., 6631.)

Anus. - Argent, a tree uprooted, esect, supported by two lions combatant betueen in chief an antique crown and in base three lizards.

CREST.-An arm in armour, embowed, in the hand a sword.

MotTo.-NeMro FIDELIOR.

Malachy O'Comor, Sen ${ }^{x}$, of Dublin, W.I. werchant, joint owner with his brother Valentine of the Mount William plantation, mar. 2ndly, after 1801, Lydia, widow of Bryan Blake of Antigua and St. V., and died at Bath 1521.

706. "Charles Graxt 177." Festoon arm. (F., 12,499.)

AnMs. - Gules, three antique crowns Or.

Crest.- - A banyan tree. Motro.-Revirescimes.

Of the Adelphi plantation and of Carron, N.B., son of Janes Grant, mar. 177 S Ann Mayer of Antigua, and died 1821.

707. "Janes Graxt" Festoon arm. (F., 12,522.)

The same design as F. 12,499 , but with a bear's head couped and muzzled in centre point. Of Antigua and Carron, N.B., died 1790. Auother of like uames was M. of C. of St. V., and died 1837, aged 64 .

708. "Michael Keane" Festoon arm.

Anus.-Argent, three salmon in pale; impaling, Azure, a tower supported by two lions combatant [? KELLY or HrNes. See this coat in Archer, 248, 302].

CREsT.-A cat o'mountain sejant proper, holding with its dexter paw a flagstaff and flag. (F.C.)

Attorney-Gen.; his will proved 1799 (513, Howe).

709. "Governor Lincoin" Festoon arm.

Probably Edmund Lincoln, Gov. of St. V. (F.M.) Not in the Colonial List.

710. "L R Phipps Mrdde Temple" Festoon arm. (F., 23,553.)

Ariss.- - *

Lake Roche Phipps, son of Wm. Phipps of Cork, took up lands in St. V. in 1777 , barrister and M. of $A .177 \mathrm{~S}$, died 25 Dec. 1787 at Bermula. He owned two plantations of 450 acres in Charlotte parish called Massaricau and Camacarabon.

* The Print room at the British Museum is closed for alterations (Ost. 1913). 
711. "Wrlliair Svagg. Middle Temple" Arm. (F., 27,526.)

ARMs. - Argent, three pheons proper.

Crest.-An arm couped, embouved, in the hand a tilting spear.

Son of Wm. Snagg of St. V., called to the Bar, Middle Temple, 1829, Sol.-Gen. for Grenada 1S38, Chief Justice of the Leeward I. 1856-68, of B. Guiana 1868-78, knighted 1859, mar. 1838 Anne, dau. of John Turner, and died at Demerara in 1878, aged 71 .

712. "William Wruly EsQ" See ante, No. 159, p. 19.

$\mathrm{He}$ was probably identical with the Chief Justice of St. V., who died at Budleigh Salterton, co. Devon, in Feb. 1828. I could not find any memorial of him in the church near there.

1775, Oct. 30, William Wylly, eldest son of Alex. Wylly of Georgia, in Ameriea, Esq. Also Campbell Wylly, youngest son. (Gray's Inn Admissions.)

\section{Tobañ.}

713. "Peter Caupbell, Esq." Chip. arm. spade shield. (F., 5024.)

ARMss.-Gyronny of eight Sable and Or.

Crest.-A hand holding a spur. MotTo.-Forget not.

Lient.-Gov., and died 1779. There was also one of the same names of Jamaica, who died in 1817 at A binger Hall, Dorking.

714. "Johr Clark. Tobago" Festoon. (W.E.B.)

Died in 1507 .

715. "Oswald Clark. Tobago" Wreath arm. (F.C.)

A Rus.- Argent, on a bend Gules between three pellets as many swans of the first. Crest.-A swan. MotTo.-PResens absensque ident erit.

716. "D. DALT" Crest.

Sir Dominick Daly went to Canada in 1812, Sec. of Lower C. 1825, Lieut.Grov. of 'lobago 1851-4, President of Edward Isle 1854-61, Gov. of S. Australia 1861-8. (IV.E.B.)

717. "Adam Fairholme, Esquire of Chapel. Lizars sculpt." Chip. arm. (F., 10,152.) Engraved about 1820. (Fincham.)

The will of Adam Fairholme of Tobago was proved in 1772 (403, Taverner). Thos. Fairholme died 1786. plate.

718. "Walter IrviNe" Arm. spade shield. (F., 16,093.) A very small

Arus.-Argent, three holly branches, each of as many leaves, banded.

CREST. - Seven arrows palewise, points upwards, and banded.

MоTTO. - SUB SOLE SUB UMBRA VIRENS.

He mar. in 1797, at Deebank, Cath. Gordon.

719. "Rowler Lascelres Esq ${ }^{\mathrm{R}}$ " Arm. spade shield in beaded oval. (F., 17,636 .)

ARMs.-Sable, a cross-crosslet Or, a crescent for a difference; impaling, Or, on a chevron Azure three thistles, between as many roses of the second [GovLD].

CREST.-A bear's head Ermine, couped, muzzled and collared.

Will proved 1797 (508, Exeter). 
720. "WruL Lindsay" Arm. (F., 18,347.)

ArMs.-Gules, a fess checky Argent and Azure, in chief a mullet, and the base undée of the third [LINDSAY of Culsh, N.B.].

Crest.-A tower. Мотto.-FiruIUs maneo.

F. 18,349 is the same plate without inscription, so probably an earlier one. Gov. of T. 1794, and died 1796.

721. "Thomas Wilson of Tobago" Ribbon and wreath. (W.E.B.) He died at sea in 1801. Will (833, Abercrombie).

For the plate of Sir Wm. Young, Bart., Gov. of T., who died in 1815, see ante, p. 17 of this supplement.

\section{Trimian.}

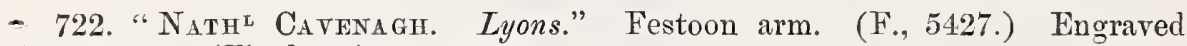
about 1790 . (Fincham.)

ARMrS.-Argent, a lion passant, and in base two crescents Gules.

Crest.-Out of a crescent Gules, a garb. Motto.-Dat Deus incrementum. Lieut. R.A., eldest son of Nathl. Cavenagh of Bath, died at 'T. 1819, aged 24.

723. "Henry Fuluer." Arm. Ca 1830-40.

Lawyer. (W.E.B.)

724. "George Lewis Garcia"

Attorney-Gen. (W.E.B.)

725. "William George Krox. Trinidad" Arm. (F., 17,371; Allen, 468.) F. 17,370 is without "Trinidad."

ARMS.-Gules, a falcon, wings expanded, within a bordure engrailed Argent.

Crest.-A falcon close. Motro.-Moveo et proficio.

Chief Justice, born 1788, died 1869. (W.E.B.)

726. "Frederick WarNer" Arm. Ca 1830-40.

Lawyer. (W.E.B.) Third son of Ashton Warner, Chief Justice. Of the Middle Temple 1835, barrister-at-law 1841, M. of C., and died 1889.

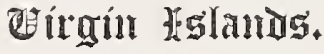

727. "John Conkley Lettsom, M.D., F.R.S., London" Engraved label. (F., 18,196.)

MotTo.-DUM SPIRAS, SPES.

Born in the V.I. in 1744 , M.D. Leyden 1769 , F.R.S. 1771, died 1815 . (D.N.B.) G. C. Peachey gives the date of plate as 1780 . (E.L.J., xi., 135.)

728. "Samder Fothergili Lettsom." Crest in garter. (F., 18,197.)

CREST.-An eagle with wings expanded, holding in its beak a shield charged with a snake. MOTTO.-A DEO PRINCIPIUM.

Third son of the above, mar. a dau. of Mr. Baron Garrow, and had a son born 1810 . 
729. "MIIRK DreR" Wreath and ribbon arm. (F., 9131.)

Arurs.-Or, a chief indented Sable, a crescent Gules for a difference.

CREST. - Out of a coronet a goat's head.

He mar. 1774 Ann Arabella Moreton, was a M. of C. before 1794, and died at Alphington, co. Devon, in 1832, aged 83. This plate is the same as F.9428 (Henry Dyer of Montserrat) with the name altered.

Probably WV.I., but not identified.

730. "Miclear Plantation" Arm. (IV.E.B.)

731. "Peter Nouaille. Greatness" Arm. (W.E.B.)

\section{ADDITIONS TO BOOKPLATES.}

\section{ANTIGUA.}

732. "George Colebrooke of Southgate Middx. EsQ"." Chip. arm. (F., 6372.)

Arus.-Gules, a lion rampant Argent, ducally crowned, on a chief Or three martlets Azure, a mullet for a difference.

CREST. - A wyvern, wings expanded, resting the dexter foot on an escutcheon Gules.

MotTo.- - Sola boNa QU一 Honesta.

Third son of James Colebrooke of Childham Castle, co. Kent, born 1729, mar. 1754 Mary Gaynor, only child and heiress of Peter Gaynor of Antigua, succeeded his brother James as 2nd Bart. 1761, M.P. for Arundel, Chairman of the E.I. Co., died at Bath in 1809. The "Gaynor" plantation was later called "Colebrookes." No. 6374 is lis brother's plate.

733. "Fountaine Cook, EsQ ${ }^{\mathrm{R}}$." Chip. arm. (F., 6678.)

Of the 1750 Cole, Oxford style. (F.C.) Will proved 1773. (Ante, 182.)

731. "Elearor Thompson 1797" in ink in the bracket. Wreath and ribbon arm.

AnMs.-Or, on a fess indented Azure three estoiles, on a canton of the second the sun in its glory.

CREST.-A dexter cubit arm in armour, in the hand five ears of wheat.

MotTo.-IN LUMine LUCEM. (E.C.)

\section{BAHAMAS.}

735. "Vincent Mathews Esq Rahama's" Printed label. Cirea 1820. (W.E.B.)

? Collector of the Customs.

736. "Generat W. Downeswets" Arm. (F., \$959.)

Third son of the Rt. Hon. W Vm. Dowdeswell by Bridget, dau. of Sir Wm. Codrington, Bart., of Antigua. A ppointed Gov. 1797, died bach. 1 Dec. 1828.

\section{BARBADOS.}

737. "Johr T. AlLEXNe EsQR" Arm.

Ariss.-Alleyve, impaling: Sable, a dexter cubit arm couped, the hand grasping three arrows [? WILLING]. Crest of Alleyne.

MOT'TO. - JE CRAINS DIEU ET N'AI POINT D'AURRE CRAINTE. (From a book p. E. G. Sinckler.) 
In St. James's Churchyard is the tomb of the Hon. John Forster Alleyne, who died 29 Sept. 182:3, aged 63. Eliz. Gibbes, his wife, dau. of .... Willing of Philadelphia, died 12 Feb. 1820, aged 55. The above impaled coat is on the tablet in the church to the Hon. Henry Alleyne (1808-1852), their 6th son.

738. "Sir Graham Briggs"

When visiting Farley Hill I was told that be used a bookplate, but a specimen could not be found. His bonks are with Lady Briggs, who resides in London. On an engraving, "The Pursuit of Pleasure," hanging in the old house, I noticed that it was dedicated to the late Sir Gralian's father, with the impaled coat of Briggs.

739. "JAs Douglas." Arm.

CRest.-A human heart proper, surmounted by a royal crown, between two eagles' wings.

He arrived in Barbados from the Isle of Wight, mar. a Miss Lessingham, purchased the Bath Plantation in St. John's Parish, and died about 1815. His youngest son Daniel Douglas, attorney, of the Mount Wilton Estate in St. Thomas's Parish, was grandfather of the present Mrs. Sinckler. [E. G. Sinckler.]

740. "JoHN Forster" Arm.

Arus.-Argent, a chevron Vert between three hunting-horns stringed.

Crest. - A stag statant. MotTo.-STA SALDO.

From a book p. Mr. E. B. Bonyun of Bridgetown. Probably a Barbadian plate.

741. (Hayses). Anonymous. Arm.

Anms.-Quarterly: 1 and 4, Argent, three crescents barry wavy Azure and Gules; 2 and 3, Gules, two billets Argent.

Crest.-A heron's wings displayed. Motto.-velis et remis.

Forwarded by the Hon. A. Percy Hayues of Bissex Hill, Barbados.

742. "Cатh. JaNe OKeden" Engraved label.

The wite of David Parry, Gov. of B. See No. 216, ante, p. 25. (F.C.)

743. "Јонм Thorxtoy" Arm.

ArMs.-Argent, a chevron Sable between three oak-leaves.

CREST.-Out of a coronet a uyvern's head and wings.

Motto.-etian inter spinas floRes. plate.

From a book p. Mr. E. B. Bonyun of Bridgetown. Probably a Barbadian

744. "The HoN ${ }^{\mathrm{BLe}}$ M I $\mathrm{Rs}$ Walter." Chip. arm. (F., 30,797.)

ARMs.-Or, guttée-de-sang, two suords in saltire Gules, over all a lion rampant Sable. On an escutcheon of pretence: Gules, on a saltire Argent a rose of the field [NETILL of Raby].

CREsT.-A stork proper dipping his beak into a whelk-shell, erect $O r$.

Abel Walter of Barbados, and Badesley in Boldre, co. Hants, mas. the Hon. Jane Nerill, dau. of Geo., 11th Baron Abergavenny, who died 1720-1, and heiress of her brothers Geo, 12th Baron, who died s.p. 1723, and Edward, 13th Baron, who died s.p. 1724. She died in 1756. She also used a label in an orwamental frame. (F.C.)

\section{BERMUDA.}

745. "Ex LIBRIS EDVARDI - LEWTON - PENNY - S.T.P. Bermvdienses apud Insvlas infeliciter submersis et turpiter in honoratis Auno Salutis mdccclXxxтo. Phillimore Auc. imp." Pict. arm. Two mell-of-war, etc., the doctor standing on a jetty.

Arus.-Ermine, two greyhounds courant barwise.

CREST.-On a coronet a lynx passant.

Greek lines above. 


\section{DOMINICA.}

746. "Avdrew GrLlon EsQR." D. Lizars Sculp?." Festoon arm. Eugraved about 1790. (Kincham.)

Arurs.-Gules, on a saltire Argent five martlets volant of the first.

CREST. - A raven on the face of a rock proper.

МоTто.-TUTUM REFUGIUM.

Of Wallhouse, co. Linlithgow, Lieut.-Col. of Scots Fusilier Guards, mar. 1800 Mary Anne Downe. John Gillon of Wallhouse plantation in Dominica and of Welbeck Street, by his will, dated 18 July 1809, demised his estates to Wm. Downes Gillon, son of testator's cousin, the above Col. Andrew Gillon. See a short pedigree in Burke's "Landed Gentry."

\section{GRENADA.}

747. Tine Right Honber Sir George Macartnex, Knight of the Order of the White Eagle and of the Batl. Armorial arms on a mantle. (F., 19,067-72.)

Lord Macartner was Governor-General of Grenada, the Grenadines, and Tobago in 1778 . (F.C.)

\section{JAMAICA.}

748. "Mrs Demany" Armorial lozenge.

Anus.-Dehany with Gregory quartering Thurgar on an inescutcheon.

The wife of George Dehany. No. 34t, ante, p. 4 . (F.C.)

749. (Hrve.) Anonymous. Chip. arm.

750. "Hon Ble Edrond Hrde EsqR" written.

ARMrs. - Azure, a chevron between three lozenges Or.

Crest.--A falcon (?) with wings expanded. (F.C.)

He was a merchant of Kingston in 1726, M. of A. for St. Andrew 1735, and M. of C. 1742 (Feurtado), mar. Mrs. Eliz. Hargreaves, widow, who died 21 June 1735, aged 55 (Archer, 262), and died in Jamaica 12 Aug. 1763. (G.M., 565.)

751. "Chas Long EsQR $C L: f e c^{t}$ " Pict. arm. Arms of Long, but the lion facing the wrong way. Evidently desigued by Mr. Long. (W.E.B.)

752. (Thos Walley Partington.) Chip. arm., name in MSS.

Arus.-Gules, on a fesse argent three Cornish choughs.

CREsT. - A hawk with wings expanded proper.

Receiver-General in 1778. (F.C.)

\section{CORRECTIONS AND NOTES.}

\section{ANTIGUA.}

P. 1, No. 1. D.D. is a slip for M.D.

P. 5, No. 37. Major H. R. Phipps, R.A., points out that Richard Shute Codrington was of Bridgwater and Combe St. Nicholas, co. Som., son of Rev. Rich. Codrington, $R$. of Bishop's Hull (died 1825), by Jane, dau. of Rev. A. Webber. (Memoir of the Family of Codrington, 1910, p. 170.)

P. 7, No. 50. This plate has been recently sent me. It bears the name "Gunthorpe." The lions' heads are collared. The Motto is : colum non ANIMUM.

P. 16, No. 130. This should read "WM FAUQUIER EsQR JUN."

Anms of Fanquier, quartering: Gules, an escutcheon within an orle of eight mullets Argent [Chamberlayne]. (F.C.) 


\section{BAHAMAS.}

P. 19, No. 159. He first went from Georgia to New Brunswick, where he became first Crown Counsel and Registrar of the Court of Vice-Admiralty, but in 1787 removed with his family to the B. In 1788 he was appointed sol.-Gen. and Surrogate of the Court of Vice-Admiralty. In 1822 he was transferred to the Chief Justiceship of St. Vincent. (Professor Siebert of Ohio, Univ. Bulletin, xvii., No. 27.) He died at Budleigh Salterton, co. Devon, in Feb. 1828, but I could not find any tablet there.

\section{BARBADOS.}

P. 21, No. 175. See Egerton MS. 1720, Brit. Mus., for correspondence in 1766 of Gedney Clarke, Sr. and Jr., about Demerara.

P. 24, No. 208. John Keeling mar. 1744 Hester, only child of Narm. Rawdon of B. and Hoddesdon, co Herts. She died 1756.

P. 28, No. 236. The Gov. was son of John Spry, D.D., Archd. of Berks and grandson of Jeffry Spry of Exeter. (Burke's "Armory.")

P. 34, No. 285. Add: Henry Gordon (will proved 1788) by Rachel his wife, dau. of Susanna Lawrence by Lawrence Lawrence of U.S.A., had a dau. Anne Gordon, who mar. 10 .July 1797 Alex. Edgar (will proved 1820), and their 3rd dau. Mary Edgar mar. T. H. Archer, M.D., whose only son was Capt. Lawrence Archer. (Cowesfield MSS.)

\section{DOMINICA.}

P. 30, No. 250. A specimen from "Bacon's Laws, 1832," has been given me here (Dominica). His full names were William Francis Balthazar Blanc. $\mathrm{He}$ was Attorney-Gen, in 1824, and several of his children were baptized at Roseau.

\section{JAMAICA.}

P. 50, No. 422. Tho. Orby Huntel was only son and heir of Gov. Robert Hunter, and died about 1769 ; the former's grandson Tho. Orby Hunter mar. 1796 Frances, youngest dau. and coheiress of Jas. Modyford Heywood of J.

P. 54, No. 453. An earlier state is without the crescent. (F.C.)

P. 66, No. 567. Gershom Williams was Judge of Admiralty and SolicitorGen. of the Bahamas in 1766 . (F.C.) 


\title{
INDEX NOMINUM.
}

\begin{abstract}
Christian Names printed in SMALI CAPITALS denote a Bookplate.
\end{abstract} Arms occur on Bookplate when Surnames are in Italic.

\section{A}

Abergavenny, Geo., Baron, 86 : see also Nevill. Abinger. Lord, 61 ; see also Scarlett.

Adair, $1,15$.

Adair, Alexander, 15 ; Anne, 1 ; James Barter Makittrick, 1 ; JAMES MAKITTRICK, 1 ; Lydia, 15.

Adams, 19.

Adams, Thomas Maxwell, 19

Adamson, 19.

Adamson, Williadr, 19

Adolpho. F., 53.

Adye, 71 .

Adye, Ralpir, 71 ; Willett Lawrence, 72

Aikman, Alex., jun., $\neq 0$; Charlotte, 40.

Aker's, 72.

Akers, ARETas, 72 ; EDMUND Fleming, 72 (2); JAMES, 72.

Alexander, 48,49 .

Alesander, Caroline Charlotte, 49 ; Jane Anne,

48; Sir Robert, 48 ; Robert Du Pré, 49.

Allen, 32 .

Allen, Anna, 32 ; Richard, 32 ; - , 3, 81.

Alleyne, 19, 85 .

Alleyne. Eliz. Gibbes, 85 ; JoHN F., 85 ; Rebecca, 19; Sir REYNOLD ABEL, 19 ; ThoMas, $19 ;-19$

Altamont, Eliz., Countess of, 52 ; Peter, Earl of, 52 .

Ames, - 22 .

Ancaster, Duke of, 76 ; Peregrine, Duke of, 78 ; see also Bertie.

Anderdon, 2

Anderdon. Anna Maria, 2 ; Anne, 2 ; Ferdin. ando, $2 ;$ John, $2 ;$ JOHN LAVICOURT, 2 ; JoHN PRoctoR, 2 (2); Mary, 2 (2).

Anderson, 59.

Anderson, Henrietta James, 59 ; Sir Wm., 59.

Anonymous, 4, 5 (2) $7,8,9,-10,11,12,17,22$,

$24,32.33,35,36,37,38,40,50,54,55,58,62$ $(2), 63,7 \pm, 76,78(2), 79,80,85$.

Anson, George Edw., 32.

Appleby (Appelby), -, 4, 32

Applewhaite, 22.

Applewhaite, Susannah, 22 ; Thomas, 22.

Arcedeckne, 34

Arcedeckne, ANDREW, 34; Anne Harriet, 34 ; Cath., 34; Chaloner, 34 .

Archer, 19, 34

Archer, J. H. LA rence, 88 : Mary. 88 ; T. H., 88.

Armstrong, WINIFRIDA WATsON, 72.
Arnold, 81 .

Arnold, Benedict, 81 ; Matilda. 81.

Arran, 76, 79.

A rundell of Wardour, 20

Arundell of Wardour, Dowager Lady, 20.

Ashby, - 42, 81 .

Astwell, 30 .

Ashwell, Charles, 30 ; Fanny, 30 .

Asprey, - 13

Assheton, WILLIA 20.

Astley, Arabella, 62 ; Sir John, 62.

Athill, 2 .

Athill, JAMES, 2; Mary, 2; Mary Ann, 7;

SamUel, 2 ; SAluUEL, JUN., 2 ; Sam. Byam, 2. Athill-Crutwell, Dr., 7.

Atwood, 18

Atwood, Thomas, 18 (2).

Austen, 77.

Austen, Caroline Cath., 77 ; Тномаs, 77.

Austin, 33.

Austin, William Piercy, Bishop of Guiana, 33.

B

Bache, - 68 .

Badeley, H. J. F., 49.

Baijer (Bayer), JоHN Oтто, 2 ; Oтто, 2.

Baillie, 34, 70 .

Baillie, Eliz., 70 ; John, 34 ; Peter, 70 ; Sam. Crook, 34; W. E., 1 ; Wm., 34, 61 .

Barbados, Library Association, 28 ; LiteRARY SOCIETY OF, 28.

Barham, 35 .

Barham, Dorothea, 35 ; Eliz., 35 ; Henkr, 35 ; John Foster, 35 ; Josh. Foster, 35 ; Lady Kath., 35 ; Luey Foster, 35 ; Mary, 35 ; Mary Foster, 35 ; Richard Harris, 35.

Barlow of Sheffield, 56 .

Barnes and Co., 36 .

Barrit, 35.

Barrit, Ann, 35 : ELEANOR, 35; HARRIETT, 35 ; Thos. Hercy, 35.

Barter, Anne, 1.

Bastard, 12.

Bastard, JoHn Pollexfen, 12 ; Judith Anne, $12 ;-, 12$

Bate, 61.

Bathurst, Louisa, 3

Bayly, 35 .

Bayly. ANNa, 35; Eliz. Arthur, 35 ; NathanreL, 35 : Sophia Magdalena. 35.

Beach, 36. 
Beach (de la Beche), Helen, 36 ; Jонn Hyxes, 36 ; Thomas, 36.

Beaufort, Duke of, $5 \mathrm{~s}$; see also Somerset.

Becker, - 66.

Beckford, 34, 36, 37, 55, 56 .

Beclyford, ANoxymous, 36 ; Anne Harriet, 34; Ballard, 39; Bridget, 58 ; Charlotte, 36;

ElIz.. 36, 37 ; Fra., 39 ; FRA. Love, 34. 36 ;

Johanna. 36 ; Maria Eliz., 36 ; Mary Ballard,

55 (2) ; Peter, 37 ; Richard, 36 ; Thos., 55 ;

WM., $36 ;-36$.

Beckles, 20.

Beckles, Edward Hynduan, 20.

Beckwith, -, 43, 64 .

Beete, 33.

Beete. JosepH, 30, 33.

Belli. 21.

Belli. Paulina, 21.

BELMORE, EARL OF, 37.

Benson, Axorymous, 37 ; Hoses, 37.

Bentinek, 67.

Bentinck, Charlotte Frances, 67 ; John Albert, 67.

Berkeley, 5. 72 .

Berkeley, Hexry Spencer Hardtyan, 72 ; Kath., 72 .

Bertie, Lady Jane, 78 ; Lady Mary, 76 ; see also Ancaster.

Best, Anne, 11

Bethel, 5 .

Bethel, Elizabeth, 5.

Bishop of Sierra Leone, 20

Blackman, 2,3.

Blackman, ANNa MIARIa, 3; JNo. LuCIE, 2 ; Mary, 2, 25 ; Priscilla, 2 ; Rowland, 2.

Blackrell, 8.

Blackwell, Philadelphia, 8

Blagrove, 37.

Blagrove, Ann, 37 ; JoHN, 37, 38.

Blake, 37, 50, 72.

Blake, Annabella, 72; Anne, 50 ; A. R., 37; Bryan, 82 ; Frances Barbara, 50 ; Lydia, 82 ; Patrick, 72 (2) ; Sir Patrick, 50 ; Thomas, 33.

Blanc, Williaß, 30 ; William Francis Balthazar, 88.

Blencowe, Frances Dorothea, 75.

Blenman, 20

Blenman. Eliz., 20 ; JoNAthaN, 20 ; T., 20 ; Timothy, 20; Wm., 20.

Blizard. Eliz, 3, 15.

Boddington, Messrs.. 77.

Bogle, 6 .

Bogle, Eliz., 6 ; James, 6.

Bogle-French, Nathaniel, 6 ; Rebecea, 14 ; see also French.

Boldero, Sophia, 49.

Bonham, 20.

Bonham, Agnes, 20 ; Pixsox, 20.

Bonnin, 3.

Bonnin, Henry Goussé, 3 ; Marguerite WingFIELD, 3.

Bonyun, E. B., 86.

Booth, Eleanor, 35 ; Sam., 35 ; -, 27.

Bourke, 37 .

Bourke, EDHund Fearox, 37 (3) ; Mary, 37.

Bourryau, Mr., 76.

Bonles, 38.

Bowles, CHA., 37 ; HenRy. 38.

Box, 5.

Boydell, John, 36 .
Boyfield, Anna Maria, 43.

Eramston, 36.

Bramston-Stone, Rev. John, 36 ; Maria Eliz., 36. Brandreth, 65.

Brassey, Maria, 45; Nath., 45.

Brathriate, 20.

Brathwaite, ЈонN, 20.

Brebner. James. 7 : see also Gordon.

Briggs, SIR GRAHAM, 86: Lady, 86.

Brisbane, James, 18 ; Willial, 18.

Brissett, 3s.

Brissett, JosepH, 38 ; Mary. 53.

Brodbelt, 38.

Brodbelt, ANoxymous, 38 ; Daniel, 38 ; Fran. CIS Righy, 38 (2); Thomas LeE, 38.

Brograve, 78.

Brograve, Eliz., 78 : $\mathrm{Wm} ., 78$.

Brooke. 9.

Brooke, J., 3.

Brotherton, 27, 36.

Broughton. 9.

Broughton, Maria, 9.

Brouncker, 72.

Brouncker. Eliz., 73; HENRY, 72. 73: MARY, 73 ; Susannah, 73 .

Bron'ne, 52, 66.

Browne (Brown), Anne, 66 ; Isabella Maria. 80 ; Howe Peter, Harquess of Sligo. 52 : JoHs, 66 ; see also Sligo.

Buchan, Earl of, 76 .

Budgen, 73 .

Budgen, Jону Sлiтtн, 73 ; Penelope, 73 ; Tho., 73.

Bulloek, 38 .

Bullock, Dorothy, 38 ; EDTARD, 38; Eliz.

Savile, 38.

Bunbury, 72.

Bunbury, Annabella, 72 .

Burden, A., 17.

Burke, Franc Is, 30.

Burnaby, 38 .

Burnaby, Eliz., 38; Grace, 38 ; Margaret, 38 ; Sir WILLIA

Burnell, 一, 8, 64 (2)

Burnett. 20 .

Burt, 81 .

Burt, Marg, 81 .

Bute. John. Earl of. 25.

Butler, Mary, 52.

Byam, 3, 4.

Byam, ANoxymous, 4; EDTARD, 3 ; Eliz.. 3 ; Frances, 4 ; ERANCIS. 3 ; GeORGE, 3 ; Grace, 3, 4, 16; Jane, 3 ; Jane Akers, 3 ; Louisa, 3 ; Lydia, 3 ; Martis, 3 ; Mary, 78 ; Phillis, 4 ; RichD. Burgh. 3,4 (2); SAMUEL, 3 (2). 4 , 16 : SAMUEL. D.D., 3 (2),

Byndloss, HeNRy, 38.

\section{$\mathrm{C}$}

Cameron, 18.

Cameron, Charles, 18 (2); Charles Hay, 18 ; Lady Margaret, 18.

Campbell, $89,61,66,83$.

Campbell, Colin, 39; DoNALD, 39 : Eliz.

Woodstock, 66 ; Fra., 39; JoHN. 39; Sir John, 61 ; MARY Eliz., 61 ; PETER, 66, 83.

Capel, Mary Ann, 21.

Caradoe Vraich-Vras, 4

Carlisle, Charles, Earl of, 27. 
Carmichact, 33.

Carritl, 36 .

Carrington, 21.

Carrington, CODRINGTON EDMUND, 21; SIR

Codrington EDMund, 21; Mary Ann, 21;

Panlina, 21.

Cassin. Fred., 72 ; Kath., 72.

Cattle, Frederic, 1.

Cavan, Richard C., Earl of, 60.

Cacenugh, st.

Cavenagh, Nath., 81 .

Chalmers, Eliz, 14.

Chamberla!ne, 87.

Chandos, Jimes Brydges, Duke of, 42.

Chauncy, 30.

Channcy, Amelia, 30 ; Chas. Snelu, 30 ; Nath., $30 ;$ Wm., 30.

Chester, Mr's., 10.

Chetrynd. 80.

Chetwyud, Isabella, 80; John, Viscount, 80 ;

William Richard, 80.

Child, Sarah, 10.

Churchill, Awnsham, 22 ; Mary, 22.

Clanricarde, Hester Cath., dall, of Earl of, 52 ; John Tho., Earl of, 52.

Clare, 39.

Clare, Margaret, 39 ; Midhael Benigrus, 39.

Clarke (Clark), 15, 21, 39, 83.

Clarke (Clark), Anne Margaret, 39 ; Caroline Maud, 15; EDWARD, 39; ELTZABETH. 39; Frances, 21; GEDNEY, 21 (2), 88; Gedney sen.. 21, 88 ; George, 39; ЈоHN, 83; OsWALD, 83 ; R. B., 21 ; SIMON, 39) Thos., 21.

Cleaver, Jane, 74 ; Wm., 74 .

Codrington, 4. 5 .

Codrington. Axonymous, 5 ; Bridget, 85 ; Caro-

line, 5 ; CHRistopher, 4 ; Chr. Bethlel, 4 , $5(2)$; Edward, 4 (2); Sir Edward, 5, 47

H. J., 5 ; Jane, 5, 47, 87 ; Rebecca. 4; Rev. Rich., 87 ; Richd. Shute, 5, 87 ; SIR William, 4,85 ; IV. J., ว.

Cole, B., $7 \mathrm{I}$.

Colebrooke, George, 85̃ ; James, 85 ; Mary, 8.5.

Colepeper, 69.

Colepeper, Frances, Lady, 69; John, Lord. 69; JoHn SPENCER, 69 (4); Ruth, 69; Wm. 69 .

Coleridge, Lnke, 21; Sarah Eliz., 21; WILLIAM HART, 21.

Collhoun, 73.

Colhoun, Rob., 73; WilliaM, 73 ; Wm. McDowall, 73 .

Colleton. 21.

Colleton, James Edward, 21 ; John, 21.

Colley, Dudley, 10; Ellen, 10 .

Collins (?), 2.

Colyear. 41.

Colyear, Lady Juliana. 41.

Colyer-Fergusson, T. C., 43 .

Comyns. 56 .

Concanen. 39.

Concanen, M., JUN., 39 ; Mathew, 39.

Conner, see O'Conner.

Conyers, 79.

Conyers, Lady Henrietta, 79 ; ЈонN, 79 ; Julia Cath., 79 .

Cook, Fountaine, $85 ;-, 45$

Cook and Johnson, 74 .

Coote, 39

Coote, EYRE, 39 ; SIR - 40.
Cor'y, 40 .

Cory, Charlotte, 40 ; Robert, 40 ; ROBERT, JUN., 40.

Cossley, Eliz, 46 ; John, 46.

Cotton, Louisa Margaret, 29 ; Lynch, 29.

Crooke, 7 :

Crooke, NiCholas, 73 ; SAMUEL, 73.

Crozier (?), 76.

Crump, Nathaniel, 5

Culleton, T., $74 ;$ - 72 .

Cumberbateh, 21 .

Cumberbatch, ABRAHAM, 21.

Cunyngham, 73, 74 .

Cunyngham, DANIEL. 73; Eliz., 73; Eliz. Philadelphia. 73; Henrietta, 74; Mary, 32 ;

Rовт., 73 ; Sir Wm., 32

Cusact. 7.

Cusack, Mary, 7 ; Patrick, 7.

Cussans, 40.

Cussans, Enphine, 40; Jane, 38; JoHn, 40 ;

John Edwin, 40; Tном ss, 40.

Cuthbert, 40.

Cnthbert, GEORGE, 40

Dacre, 27.

D'd guilar, 53

D’Aguilar, Leah, 44 ; Rose, 53 ; S., 53.

Dallas, 40 .

Dallas, Alexr., 40 ; Alexander R. C., 40 ; CHARLES Robert KING, 40; Julia Maria, 40 ; Robert, 40 (2); Robert CharLes, 40 ,

41: STUART GEORGE, 40 .

Dalling, 41 .

Dalling, Eliz., 41; Colonel ЈoHN, 41 ; Sir WINDHAM, 41.

Dalrymple, 30.

Dal rymple, ALExr., 30 ; HuGH, 30.

Dalston, Cath.. 16; Sir Cha., 16.

Daly, D., 83 ; Sir Dominick, 83 ; JAMES, 41.

Daniell, 22.

Daniell, JоHN, 22 ; WilliaM, 22.

Darling, W., 63,70 .

Davy, 9.

Davy, Sir Humphry, 9 ; LADY JANE. 9.

Dawes atias Willock, Rev. Chas. Wm., i7.

Dawhins, 41.

Dawkins, Eliz., 58; HexRY, 41 (3); Lady

Juliana, 41.

Dehany, $41,66$.

Dehany, Eliz. Favell, 41 ; GEorge, 41 (2), 87 ; Lucretia Favell, 66; Mary, 41; Mrs., 87; Sarah, 41 ; W. K., 41 .

de Lancey, Mary, 75 .

Delap, $\tau$.

De Miranda, 46.

De Miranda, Donna Leonora, 46

Dering, 78 .

Vering. Eliz., 78 .

Desbrisay, Kev. T., 22 ; THEOPHILUS, 22.

de Tabley, Baron, 49 ; see also Leicester.

Devereux, Earl of Salisbury, 6.

De Visme, Harrictte, 46 ; Philip Nath., 46.

Devon, CHARLES, 56 ; Mary, 56.

Dervar, 74

Dewar, DAvid, 74 ; Geo., 74 ; J.E., 74 ; JAMES, 74 (2) ; JaJies C., 74; ЈоHг, 74 ; Penelope Susana, 74.

Dewhirst, Cath., 72. 
Dobyns, 5.

Dohyns-Yate, Caroline Eliz, 5.

Donovan, 5.

Donovan, Caroline Eliz., 5; Margaret, 38 ;

RichaRD, 5 ; Timothy, 38 .

Dottin (Dotin), 20, 22.

Dottin (Dotin), Eliz., 20 ; HENRY, JUN., 22.

Douglas, $6.60,74,86$.

Douglas, Daniel, 86; ELIz. ST. LEGEr, 74 ;

Henry, 18 ; JAMEs: 86 ; Jas. Geo., 74 ; Mary:

18,$74 ;$ WALTER, 5 .

Dowdeswell, Bridget, 85: W., S5; Wm., S5.

Downe, Mary Anne, 87.

Drax, 22.

Drax, EDWARD, 22 ; Mary, 22 (2); THomas

ERLE, 22.

Ducie, Lord, 18 ; see also Moreton.

Dun, 42 .

Dundas, Thonas, $32 ;-, 29$

Dunmore, MurRaY, EARL OF, 19.

Dunn, 67.

Dunn, Eliz., 67 ; JAS. VIRGo, 67.

Dupuy, Jane, 72 .

Ducr, 6, 13 .

Duer, ALEX, 6 ; John, 6; Theodora, 13 ; WILL., 6.

Dyer, 1s. 67.

Dyer, Ann Arabella, 85; HeNRY, 67, 85; Henry Moreton, 18 ; John, 67 ; MARK, 67 , 8.5.

$\mathrm{E}$

East, 42.

East, Caroline Eliza, 42 ; JAMEs BuLlER, 42 ; SiR JAMES Buller, 42.

Edgar, Alex., 88; Anne, 88; Mary, 88.

Edwards, 42.

Edwards, B.. Jun., 42 ; BRYAN, 42 (2) ; Martha, 42 ; Zachary Bayley, 42.

Effingham, EARL OF, 36; KATHERINE, COUNTeSs of, 37 ; Thomas, Earl of, 37

Elletson, 42,59 .

Elletson, Anna Petronilla, 42, 59 ; Roger, 59; ROGER HOPE. 42

Ellis, 42.

Ellis, Antoinette, 42 ; George, 42 ; George, jun., 42 ; JoHN, 42 ; Susanna Charlotte, 42.

Elmslie, Harriet, 57 ; John, 57.

Elmy, 33.

Elmy, JAMES, 32, 33.

Elvareh, Lord of Penrose and Brythlyn, 4.

Elystan Glodrydd, 4.

Emley (?), 51.

English, ARThur William, 80 ; Mary Ollyffe, 80.

Errington, GEORGE, 22 .

Erskine, 42, 43.

Erskine, ALEXANDER, 42, 43 .

Esdaile, 71.

Esdaile, Eliz, 71

Estriage, 74 .

Estridge, ElIZA, 74; Eliz, 74; John, 74 JOSEPH, 74.

Evans, 65.

Everard, James, 20.

Eyre, 53.

Eyre, Jacyntha Charlotte, 53.

Fagg, Sarah, 17.

Fairchild, 22.

Fairchild, HamLet, 22 ; John, 22.

Fairholme, ADAM, 83; Thos., 83.

Fanshawe, Cath.. 11 .

Furnhorough, CHARLES LONG. LORD, 5.5; see also Long.

Farquhar, 57.

Farquhar, Cath., 57 ; Sir Walter, 57.

Farvell. 79

Farrington, 45

Fuuquier, 16.

Fauquier, Cath., 16 ; Charlotte, 16 ; Fraxcis,

16 (2); Grace, 16; Mary, 16 (2) ; THoMAs,

16 ; Wu., 16; Wu., JUN., $16,87$.

Fan'ne, 11.

Feavan, 43.

Fearon, Anna Maria, 43; JoHN PETER, 43; Tho., 43.

Fermor, Lady Henrietta, 79 .

Fetherston, 28.

Feuilleteau, Eliz., 73 ; Susannah, 73.

Fenton, 74.

Fenton, Axonymods, 74 ; Jane, 74 (2); Wm., 74.

Finch, Mary, 73; Wm, 73.

Firebrace, Sir Basil, 34; C. W., 34; Eliz., 34 ; John, 34; Mehetabel Christian, 34; WILLIAM NEWTON, 34.

Fitzhugh, 32.

Fliqht, 68

Foley, 5 .

Foley, Lady Caroline, 5.

Ford, 43.

Ford. Gilbert, 43 (2).

Forster, 86.

Forster, JoHN, 86.

Foster. 35. 43.

Foster, Eliz.. 35 ; INGHAM, 43 ; John, 35 (2) ; Miss, 19 ; Тном $\mathrm{As}, 43 ;-, 72$.

Fonle, 43.

Fowle, Bridget, 43 ; Tho. F., 43 ; William, 43 .

Foyster, 43 .

Foyster, CALEB, 43 ; Sam., 43.

Francis, Mary, 9

Franco, 44, 56.

Franco, Abraham, 44, 56 ; EpHralu, 44 ; Esther, 56 ; ЈАСОВ, 43, 44 ; Joseph, 44 ; Leah, 44 ; Moses, 44 ; RAPHAEL, 44 ; Simha, 44.

Frankland, 58, 75

Frankland, Roger, 58 ; Sophia Cath., 58

Fraser, 6.

Fraser, WILLIAM, 6.

Freeman, 75 .

Freeman, Arthur, 15 ; Byam, 18 ; Eliz., 75 ; Frances Dorothea, 75; Harriet, 18; Margaret, 15 ; Mary, 16 ; Rohert, 16 ; Sambrooke, 75 ; STRICKLAND, 75 (2); W. P. WILliaMS, 75.

Erench, 6.

Freneh, Eliz., 6 ; John, 6 ; Mary Arabella, 6 ; Nath., 6 ; NATHANIEL BOGLE, 6 ; WILLIAM NATHANIEL, 6.

Frere, 22.

Frere, John, 22 ; Susannah, $22 ;-, 22$.

Frye, 17, 67.

Frye, John, 17 ; JoHN RAveL, 67 ; Sarah, 67 W., 17 : William, sen., 67. 
Fuhr, 4 t.

Fuhr, Chas., 44; EDITARD, 44 ; JohN PHILIP, 44

Fuller. Eliz., 62 (2) ; HENRY, S4; John, 62 ; Saral, 62 ; Stephen, 62

Furlong, Mars, 8; Williaj, 6.

Furnall, Jane, 16.

\section{G}

Gale, 44

Gale, Eliz., 44 ; WILLIAI, 44.

Galloway, JAMEs, 44.

Gallney (Galway), 75 .

Gallwey (Galway), Emily Anne, 75; Mary, 75 ; StePhen Payne, 75 ; Sir William Payne, 7.5.

Galpine, Eliz., 11 .

Gavorund, 45

Garbraud, CALEB JoHN, 44 ; John, 44 ; Joshua, 44.

Garcia, George LewIs, 81 .

Gould, 83.

Gaidner, 45.

Gardner, ALAN, 45 ; BARON, 45.

Garnett, 75 .

Garnett, Јон N. 75 (2).

Garnier, Isaac, 77 ; Margaret, 77, 78

Garrow, Baron. 8t.

Gaynor, Mary, 85 ; Peter, 85.

Gent, Fra., 39

Georges, 75.

Georges, Eliz., 75 ; WILLIAM PAYNE, 75.

Gibbes, 22.

Gibbes, Agnes, 22 ; SIR Prille, 22.

Gibbous, 52 .

Gibbons, Nliz., 52 ; Wm., 52 .

Gilbert. 6.

Gilbert, NATHL., 6 .

Gilder, Isabella Maria, 76 ; Rev. Jonathan, 76.

Gill, Thos., 23 ; THus., JUN., 23 ; W

Gillon, 87.

Gillon, ANDREW, 87 ; Mary Anne, 87 ; John, 87 ; William Downes, 87.

Gingell, W., 8 (2).

Gloster, 6.

Gloster, ARCHD., 6 ; Eliz., 6 ; Russell, 6.

Golebor'n, 46.

Goleborn. Cath., 46 ; THos. LrNCH, 46.

Gomm, 23.

Gomm, Eliz., 23 ; Mary Alleyne, 23 ; Sophia, 23 : Wm., 23 ; Sir William MaYNard, 23. Goodwyn, 37

Gordan, 45.

Gordon, Anne, 88 ; Cath., 45, 59, 83 ; Henry, 88 ; JAMEs, 7,45 ; James Brebner, 7 ; JоH , 45 (3) ; Maria, 45 ; Mrs., 45 ; Rachell, 88 ; Sybella, 45 ; WILLIAM, 45.

Goulbu:n, 46 .

Goulburn, EDWARD, 46 ; EDWARD MErRICK, 46 ; FREDERICK ANDERLECH' 46 ; Harriette, 46 ; HenRy, 46 ; Jane, 46 ; Munbee, 46 .

Grainger, 75.

Grainger, JAMES, 75

Grafton, Henry, Duke of, 60.

Graham, 39.

Graham, Colonel C. D., 39 ; Margaret, 39.

Grant, Ann, 82 ; CHA RLES, 32 ; JAMEs, 82 .

Grasett, 23.
Grasett. Ann, 23 ; ELLIOT, 23 ; HENRY J MMES, 23 ; Rev. Jas. 23 .

Gravelot, H., 79.

Greatheed, 76 .

Grentheed, Bentie, 76 ; Lady Mary, 76 ; R. W. 76 ; Sam., 76.

Gregory, $41,46,54$.

Gregory, Mary, 41; Mathew, 41, 46,54 ; Jane, $5 \pm$; John, $46 ;-, 73$

Gretton, J., 45 .

Griffiths and Weigalls, 41,54 .

Grimston, Lady Kath, 35 .

Girosett, 46.

Grosett, JAMEs, 46; John Rock, 46 ; Schaw, 46.

GUADALOUPE, GOVERNOR OF, 3:

Guiana, Catredral, 34 ; Diockse of, 34.

Gun, 31 .

Gunthorpe, ANoNymous, 7 .

Gutteres, M., 56 ; Mlary Eliza, 56.

\section{H}

H., N., 19 .

Hoggatt, 23.

Hagratt, Nath., 23 ; O., 23 ; OTHNIEL, 23 ; susannah, 28 ; WILLIAM, 23.

IItale, 60 .

Hale, Bernard, 61 ; Martha, 61.

Hall, $46,47$.

Hall. Cossley, 47 ; Eliz., 46 ; JAMES, 46 ; James Ashley, 23 ; Jane, 5, 47 ; JAsper, 47 ; Josere, 47 ; Mary, 53; Thomas, 53 ; WILLIAM JAMES, $46,47$.

Halliday, 7.

Halliday, Francis Delap, 7 ; Francis E., 7 ; JOHN DELAP, 7 .

Hamilton, 76,79 .

Hamilton, ALExANDRA, 69 ; Cath., 79 ; Euphemia, 78 ; IsABELLA, 76 ; Wm. Leslie, 76.

Hanpson, 47

HAMPSON, 47 ; Sir Geo. Fra., 47 ; Mary, 47.

IIandley, 79 .

Handley, Joseph Chas., 79 ; Rosina Adelaide, 79.

Hankey, 42.

Hardtman, 72 .

Hardy, 47.

Hardy, Thomas DuFfus, 47.

Ilarenood, 24.

Harewood, EDWARD, EARL OF, 24; EDWABD, LorD, 23 ; see also Lascelles.

Hargreaves, Eliz., 87.

HARMAN, 7 .

Harman, Mary, 7 ; Mary Ann, 7 ; SAduel, 7.

Harnage, Mary, 2.

Harrison, Dorothy, 38.

LIart, 76 .

Hart, Амту., 76 ; Јонм, 76 ; Martha, 76.

Irartopp, 48 .

Hartopp, Cath. 48 ; Cheverton, $4 \mathrm{~S}$.

Harcey, 29, 31 .

Harvey, Sir Henry, 29; JAMES WIDDRINGTON SHAND, 31: John, 29: Sarah, 29; SIR THoMAS, 29.

Hasell, Jane 14.

IIaugliton, 51.

Haurhton, RICHARD, 47.

llawtayne, 24 . 
Hawtayne, WM., 24.

Hay, 31. 36, 47.

Hay. Charlotte, 36 ; Eliz., 36 ; Lady Eliz. 50 : G. C., 47 ; JAMeS, 47 ; J AMeS W., 47 ; Lord John, 50; John Baker, 47; Lady Margaret, 18: Tho., 36.

Hayle, 67.

Hayle, GEORgE, 67.

Haynes, 86.

Haynes, Anonymous, $86 ;$ A. Percy, 86.

Heath, RICHARD, 48 .

Heming. 48.

Heming, ANonYmous, 48 (2); Richard, 48,50 ;

SAMUEL, 48.

Hendersou, 48.

Henderson, ALExandra, 48.

Henslon, 65.

Henslow, Rev, Edward Pering, 65; Honor MARY GEORGIANA, 65.

Hering. 45.

Herring (Hering), Cath., 45 ; Julines, 45.

Hext, 26.

Heysham, 7.

Heysham, Sarah, 7 : WH., 7.

Hey wood, Frances, 88 ; JAS. MODYFoRD, 48, 88.

Hibbert, 48,49 .

Hibbert, ARma Johannis NembHard, 48 ; Charles R. C., 49; Eliz. Margaret, 50 ; Florence Jane, 49; Fred. Drummond, 49; GEORge, 48 ; Hester Lonisa, 49; Hugb Robert, 49 ; Julia, 49 ; Leicester, 49 ; Margaret Dora, 49 ; Nath., 50 ; RoberT, 49 ; RoberT Fiennes, 49 ; Sophia, 49; Thomas, 48, 49 ;

VERONICA, 49 ; WASHINGTON, 49.

Hithouse, 8

Hilhouse, Emma, 8; James, 8; JaMES MARTIN. 8 ; Martin, 8 .

Hill, 77.

Hill, Ann, 77 ; Tho., $77 ;-, 61$.

Hillary, WILITAM, 24.

Hinde, 50.

Hinde, GEORGE, 50 ; Poyntz. 50 ; Robt., 50.

Hinds, 24 (2).

Hinds, BENJAMIN, 24 ; WILLIAM, 24.

Hobart, 2.

Hobart, Mary, 2.

Hodlges', 50,73 .

Hodges, Anne, 50 ; Anonymous, 50 ; Eliz., 9 ; Frances Barbara, $50 ;$ John, 50 ; Тноміаs, 50 .

Holland, 49.

Holland, Eliz., Lady, 65; Henry Richand, LORD, $65 ;-, 60$.

Holland-Hibbert, ARthor HeNry, 49 ; Ellen, 49.

Hollaxd House, 65 .

Holloway. 13.

Holmes, J. H ENRY H., 33.

Home, Eliz., Countess of, 52 ; Wm., Earl of, 52. Hoppner, -, 52 .

Horsford, Eliz, Maria, 8; Geo. FAHIE, 8; Mary: 8: ROBERT MARSH, 8 .

Hothersall, 26.

Hothersall, Tho., 26 ; Tho., jun., 26.

Hongh, Eliz., 34

Houghton, 63 .

Houstoun, Alex., and Co., 77

Howard, 27,36 .

Howard, Eliz., 37 ; Sir Geo., 37 ; Thomas, Lord, 37.

Howe, Gambier, 69.
Hughes. - , 58, 73.

Hume. 55.

Hume, Sir Abr., 55 ; Amelia, 55.

Hunt, IsAAC, 24 ; Leigh, 24.

Hunter, 50.

Hunter, Eliz, 50; Frances. 8S; JoHN, 50;

ROBERT, 5U, 88 ; 'THOMAS ORBY, 50, 88 (2).

Huntly, - 13.

Hart, Sophia Eliz., 11.

Hutcheson. 8.

Hutcheson, ARCHIBALD. 8 ; Eliz., 8; Mary, 8 ; Rebecca. 8.

Hyde, 39, 50, 87 .

Hyde, ANONYMOUs, 87; EDMOND, 87; Eliz., 87 ; JоHN, 50 (2)

Hynes, $36,51.82$.

Hynes, Helen, 36; John, 36 ; P. S., 51.

\section{I}

Inglis, 51 .

Inglis, JAMES, 51

Ingram, Eliz. Arthur, 35.

Irvine, 83.

Irvine, Cath., 83 ; WALTER. 83.

Irving, 51.

Irvinus, MIAJOR, 51

\section{$\mathrm{J}$}

Jamaica, See of, 54, 62 .

JAMAICA-

BISHOP OF, 54.

MORANT BAY CIRCULATING IIBRARY AND READING ROOMI, 66.

Royal AgRICULTURAL Soctetr, 66.

UNION HALL LIBRARY. 66.

James, 37,51 (3).

James. Hadghton, 51 ; Hugo, 51 ; Williail

RHODES, 51 .

Jarrett, Anne, 51 ; Herbert Nenton. 51 ; Herbert Newton, jun., 51.

Jaritis, 8.

Jarvis. Chas. MACQUARIE GEO., 9: EDWIN George, 9; Eliz., 7 : Frances, 8 ; GeoreE RALPH Payne, 8; Philadelphia, 8; I'HoMAS, 8.

Jefferson, Martha, 76

Jenkyns, 55.

Jenkyns, Frances, 5̃ ; Wm., 55.

Jervis, John. Earl St. Vincent, 60 ; Mary, 60.

Jewers. A. J., 74.

Johnson. 9

Johnson, Eliz., 9; Eliz. Anne, 9; G., 24, 70 ; GoDschaLL, 9 ; John, 9; MIary, 9; RoBERT GoDsCHALL, $9 ;-, 19$

Johnston, 51 (2).

Johnston, A., 50 ; JoHN, 51 (2).

Jolly, 73.

Jolly, John, 73.

Jones, 24

Jones, Mary, 20; Robert Burnett, 20 ; Sarah, 41 ; VALENTINE, 24 (2).

Jopp, 51,52 .

Jopp, CHARLES, 52 ; Eleanor, 52 ; JANEs, 52 ; KEITH, 51.

Julius, 76 .

Julius, Ellen, 76 ; Fred. GILdER, 76 ; GEo. CHAS., 76 (2); Isabella Maria, 76. 
K

Keane, 82.

Keane, MICHAEL, 82 .

Keeling, 24.

Keeling, Hester, 88 ; John, 24, 88 ; Jos., 24.

Keith, 52.

Keith, Sir Basil, 52 ; RoвERT, 52 ; Sir Robert Murray, 52.

Kelly, 52, 82

Kelly, Dennis, 52 ; Eliz., 52.

Kennedy, 53.

Kerr, 9, 23.

Kerr, Charles, 9, 52 ; Eliz., 23 ; $J_{\text {ANE, } 9}$; Lord

Robert, 23 ; -9

Kilmaine, John, Lord, 66 ; see also Browne.

King, Benj., 18 ; Mary, 18.

Kirk, J., 30, 77 ; - 22.

Kinnan, 9.

Kirwan, John, 9; MaTTHEw, 9.

Knight, $; 3$.

Knight, Henrietta, 74 ; JNo., 73

Knox, 84.

Knox, William George, 84.

Knutsford, Eliz. Margaret, Lady, s0 ; Henry, Lord, 50; see also Holland-Hibbert.

L ..... M., 32

Laing, 30,52 .

Laing, Allan Stewart, 30 ; ChARLES ColemaN,

30 ; Eliza, 30 ; JAMEs, 30 ; MALCOLM, 52.

Lake, 39.

Lamack, Sophia Magdalena, 35.

Lambart, Lady Eliz. Jane, 60.

Lambert, 23.

Lambert, Jane, 23 ; Simon, 23.

Lander, - 22.

Lanoford, 13.

Langford, Isabella, 17 ; Jonas, 17.

Langford. Brooke, 9

Langford-Brooke, Lilian, 9 ; Maria, 9 ; Thoi As, 9

Laroche, Eliz. Rachel Anne, 10; JAMES, JUN., 10 : James, sen., 10.

Laseclles, $21,24,83$.

Lascelles, Edward, 21, 24; EDw ARD, EARL OF HAREWOOD, 24; EDWARD, LoRD, 24 ; Frances, 21 ; RowLEy, 83.

Lavington, Lord, 75 ; see also Payne.

Lawes, 52.

Lawes, Eliz., 52 ; Mrs. ElizaвETH, 52 ; James, 52 ; Mary, 52 ; Sir Nich., 52 ; TeMPLE, 52.

Lawford, Louisa, 41

Lanrence, 53.

Lawrence, ARthur Johnstone, 53 ; Charles, 53 (2) ; GeORGE, 53; Jacyntha Charlotte, 53 ; J. ThARP, 53 (2) ; Julia, 53 ; Lawrence, 88 ; Mary, 53 ; RICHARD JAS.. 53 ; Sarah Brissett, 53 ; Susanna, 88 ; W. F., 53, 67. Lanrie, 5s.

Lawrie, W. B. K., 53 ; WM. KENNEDY, 53.

Lawson, Ellen, 50; Sir Wilfrid, 50.

Layton, 27.

Lechmere, Eliz.. Lady, 27 ; Nich., Lord, 27.

Lee. 31.

Lefroy, Sir Henry, 29 ; John Henry, 29 ; 29 (2).

Legge, 43 .
Legge, Bridget, 43 ; Rich., 43.

Leicester, 49.

Leicester, Henry A. 49 ; Letitia Kath. 49

Leigh, 34, 36. 42 .

Leigh, Caroline Eliza, 42 ; Cath., 3. ; James Henry, 42 ; Johanna, 36 ; John, 34, 36.

Leightin. 26.

Leighton, LT.-GEN. Francis, 26;

Leman, 59.

Leroux, 10.

Leroux, JAcoß, 10 ; Sarah, 10.

Lessingham, Miss, 86 .

Lesturgeon, Rebecca. 5 .

Lettsom, JoHN COAKLEY, 84 ; SAMUEL FOTHERGILL, $\delta t$.

Lewis, Anna Maria, 54 ; Jane, 54 ; МАттнеW, 54: Wm., 54; Williai, JUN., 54.

Leybor'ne. 31 .

Leyborne. WILLIAM L., 31.

Lincoln, Edmund. 82; Governor, 82.

Lindsay, 84 .

Lindsay, WILLIAM, 84.

Lindsey, 10.

Lindsey, William, 10; Rev. IV., 10.

Lintorn, 61

Lipscombe, 54.

Lipscombe, CHR., Bishop of Jamaica. 54.

Lisle. 10.

Lisle, Eliz., 10 ; Fermer, 10 ; Tов IAs, 10 ; Wm., 10.

Livingston, Noel B., $3 t$.

Livius. 3 5.

Livius, BARHAM JOHN, 35: GEORGE, 35 (2);

George Peter. 35 ; JoHN Barham, 35 ; Lucy Foster, 35 ; Mary Foster, 35 ; Peter Lewis, 35. Lizars,,- 67 .

Lloyd, Johanna, 36 ; Richard Bennett, 36.

Lonq, 54, 55.

Long, Amelia, 55 ; ANonymous, 5 t, 5 a ; BeEsTON, 54, 56; Catherine Ilaria, 57; CHAS., 55 (2), 87 ; Sir Charles. 55 ; Charles, Lord Farnborough, 55; CHARLES BECKFORD, 55 (2); EDWARD, 55; EDWARD BEESTON, 54 (2), 56 ; Frances, 55 ; Jane, 55 ; Mary, 54, 55; Mary Ballard. 55; RoBerT B., 56 ; SaMUEL, 54 (2), 57 ; Sarah, 56 ; Susanna Charlotte, $42 ;-, 54$.

Lonsdale, James, Earl of, 25 ; Mary, Countess of, 25.

Lopes, 56.

Lopes, Esther, 56; Sir RALPH, 44, 56.

Losaek, 76.

Losack, ANONYMOUS, 76; Geo., 76; Richard Hawkshaw, 76

Lousada, 56 .

Lousada, David, 56 ; Mary Eliza, 56 ; PERCY, 56 ; Percy Martindale, 56.

Love, 34, 36 .

Lovell, 25.

Lovell, Eliz., 25 : Philip, 25 ; RoBert, 25.

Lowe, 11.

Lowther, Sir James, 25 ; LADY MARY, 25.

Lumley, 29.

Lumley, Louisa Margaret, 29 ; Mary, 29 ; Richard, Earl of Scarborough, 29; WILLIAM, 29 .

Lyneh, 2.

Lynch, Mary, 2 ; Nich., 2

Lyon, 10,56 .

Lyon, Benjamin. 56, 57; Colley, 10 : Geoffrey, 10; Henry, 10 ; Jane, 10. 
II

Macartney, Sir George, 87.

Macaulay, 57 .

Macaulay, Lord, 57 ; ZACHARY, 57.

MicBurnie, ArNEs, 31.

Micdonall, 77 .

Mcdowall, Eliz., 77 ; William, 77.

$I^{\bullet} E$ Evy, $7 \mathrm{I}$.

M'Evoy, CHRISTOPHER, 71 ; JoHN, 71 ; Hichael, 71

M'Intosh, Eliz. 14.

McLean Plantation, 85.

McNAIR, 57 .

Macnemura, 18

Macnemara, Mary, 18 ; Mich., 18.

Mc Queen, 40.

$\mathrm{M} \mathrm{I}^{\mathrm{C}} \mathrm{Queen}$. Euphine, 40.

Madden, 57.

Madden, Harriet, 57 ; Richard Robert, 57.

Maddison, 8.

Maddison, Eliz. Maria, 8 .

Maitland, 77

Maitland, Jane, 77 ; RICHARD, 77 ; THoMAs, $7 \tau$.

Makittrick alias Adair, Anne, 1 ; James, 1.

Manniny, 77 (3).

Manning, Anna Maria, 2 ; Caroline Cath.. 77 ; Sarah, 65, 77 ; WilliaM, 2, 77 ; William, JuN, 77 .

Mansfield, 48 .

Mansfield, J. Rushton, 48.

MARKoE, 71 ; Francis Hartman, 71 ; Peter. 71 ; Philip. 71 ; $\mathrm{Wm}, 71$.

NIarley, 8 .

Maryat, 31.

Marryat, Charles, 31 ; Charlotte, 31 ; JOSEPH, 31 .

Marshall, Frank Evans, 1 ; Julian 1.

Martin, 10, 11. 12, 13.

Martin, Anne, 11; Catherine, 11; Charlotte,

11 ; Elizabeth, 11; Sir Henry, 11, 12; Henry Byam, 11 ; Sir Henry W., 11 ; JosIaH, 10, 11 (2); Judith Anne, 12 ; Mary, 10; SAMUEL, if (2), 11 (3): Sophia Eliz.. 11; Thomas Byam.11; WILliaM, 10, 11 ; William Byam, 11; Sir IVm. Fanshawe, 11 (2); Willian Thomas, $11 ;-, 10.11$.

Mason, ABRA HAM, 25.

Mathew, 77.

IIathew, Aun, 77 (2); Anonymous, 78 (2); DANIEL. 78 (2) ; DANIEL BYAM, 78; DANIEL DERING. 7S ; EDWARD, 78 : Eliz., 78 ; Euphemia, 78; GEORGE, 78; SIR GEORGE BENveNuto BucKuEY, 79; IsAaC, 77 ; Jane, 77 ; Julia Cath., 79 ; Margaret, 77; Mary, 78 ; Penelope Susanna, 74; Rosina Adelaide, 79 ; WILLIAM, 77, 78, 79.

Mathews, VINCENT, 85; W., 17.

Mathison, 57 .

Mathison, Cath., 57; GILBERT, 57.

Nawbey. Sir Joseph, 46.

Maxwell, 12.

Maxwell, WM., 12.

Mayer, Ann, 82.

Maynaid, 25 .

Maynard, JоHN, 25 ; Joseph, 23 ; Margaret, 25 ; Mary Alleyne, 23; WiLLIAM. 25.

Mellas, Ann, 35.

Melvill. 33.

Melvill, Roв ert, 33.
Mendes, IsAAC, 57.

Mendez Da Costa, 57.

Menciez Da Costa, Enanuku, 57 ; Lady Rebecca, 57 .

Michell, -, 40 .

Nilliken, 79.

Milliken, JAMES, 79 .

Nills, 73, 79

Mills, ANoNymous, 79 ; Cornelia, 79 ; G EORGE GALWEY, 79 (2); Lucretia, 73 ; Mary Ollyffe, 80; Mathew, jun., 73, 79; PAITFikLd, 80 ; Peter Matthew, 79 (2); Peter Mathew, jun., 79 ; THOMAs, 79 .

Milnes, 67.

Milnes, Charlotte Frances, 67 ; Governor. 67 ; Robert Shore, 67.

Milton, - 10.

Moduford, 48.

Molyneux, Crisp, 38 ; Eliz., 38.

Mon\%o, 55.

Monro, Frances, 55

Hoore, 5 i.

Moore, Catherine Maria, 57 ; Ellen. 10; Henry. 57, 55; SIR HeNeY, 57; John, 10; LADY, $5 \mathrm{~s}$.

Horant, 58.

Morant, EDWARD, 58; Edward, sen., 58: Eliz. 44; George, 58; Mary Whitehorne, 5s; JoHN. 58 (3) ; J. LUSHINGTON, 58.

Mordaunt, Geo., 12 ; Mary, 12.

Wore. 53.

Noreton, 18.

Moreton, Ann Arabella, 85 ; Anne Louisa, 18 ; Charles, 18.

Merris, 12.

Morris, Sir Chr., 62 ; Eliz. Anna Maria, 62 ; Henry Gage, 12; Mary, 12; VAL., 12 ;

VALENTINE, 12.

Nor'se, 33.

Morse, Harriet, 33 ; Rob., 33.

Marson, 67.

Morson, H. L. Douglas, 67 ; Walter, 67 ; WALTER S., 67.

Morton, Donuglas, Earl of, 60.

Mountaine, R., 40, 75 .

Mowbray, 27, 37 .

Muirhead, 46

Nunbee, 58.

NLunbee, Bridget, 58 ; Eliz., 58 ; Gore BoLAND, 58 ; Sophia Cath.. 58 ; VALENTINe. 58.

Munio, GEORGE GuN, 31 ; T. M., 32.

Murvay, 7, 52, 59.

Murray, Cath., 59; GEorge, 58; William. 58.

Musgrave, 68

Musglave, Richard, 69.

N

Napier, 65.

Napier, Edw. Berkeley, 65 ; Letitia Sarah, 65.

NASSAU LIBrary, Bahamas, 19.

Neave, Miss, 54 .

Neele, -, 42 .

Nelson, 15,71 .

Nelson, Lady Edith, 13 ; Frances Herbert. Viscountess, 71 ; Viscount, 71

Nembhard. Letitia Hamilton, 49 ; Mi., 49.

Netill of Raby, S6. 
Nevill, Jane, 86

Nicholas, Hary Arabella, 6 .

Nisbet. 69.

Nisbet, Frances Herbert, 71 ; Josiah, 71 ; WALTER, 69 .

Nixon, 59

Nixon, Јонх, 59 (2)

Norris, Charlotte, 16

Yorth, 55.

Nouaille. Peter, 85 .

Thugent, 12, 59.

Nugent. Admiral Sir Cha. Edmuxd, 59 ; E. 59; GeORGE. 59; SIr GEORGE, 59 ; Walter, 12.

\section{0}

O'Connor. S2.

O'Connor, Lydia, 82 ; MALACHY, 82 ; Valentine, 82.

Ogitvy, 12.

Ogilvy, Charlotte, 12; John, 12; SIR JонN, 12.

Orle, Anna Petronella, 59.

Okeden, 25.

Okeden, CATH. JANE, 25, 86 ; Edmund, 2.) George Fitziaurice Parry, 25.

Oliver, 2, 13, 17.

Oliver, Anne, 2, 64: CharLes L., 13 ; Elizabeth, 18, 64; Harriet, 18; Isabella, 17; Maria, 45 ; Rich ARD, $12,13,45$; Robert, 64 ; Sam., 64; Thomas, $2,13(2), 17$ (2); Thomas, jun., 13: Thonas William, 13 ; Vere L. Oliver, 13 (2); William Henzey, 13.

Olton, 19 .

Olton, Rebecca, 19

Orby, Eliz., 50 ; Sir Tho., 50

Ord $\overline{5} 9$.

Ord, ANNA Petronella, 42, 59 ; James, 59 .

Orgill, 59 .

Orgill, Henrietta Jane, 59; NaUnton T., 59 .

Orton, 80

Orton, Jennett Payne, 80.

Ormond, Duke of, 8 .

Osboine, 22, 26.

Osborne, Agnes, 22 ; Eliz., 25 ; Samuel, 22, 25.

Ottley, 80 (3).

Ottley, Brooke TAYLOR, 80 (2); D., 80 ; Drewry, 38; Grace, 38; Isabella Maria, 80 ; Priscilia. 80; SIR RICHARD, 80.

Oughton, 13.

Onghton, SIR ADOLPHUS, 13 ; JAMES ADOLPHUS DICKRNSON, 13; LIEUT.-GENL, 13 ; IIary, 13

Pallmer, John, 5̃ ; Mary, 55.

Pare, John, 28; Kath., 28.

Puris, 69.

Paris, Edw., 69 ; Ferdinando JoHn, 69

Parker, 42.

Parker, Antoinette, 42

Parkyns. Anne Cath., 29.

Parry, 25

Parry, Cath. Jane, 25, 86 ; David, 25, 86 ; TноIAAs, 25 ; THOMAS, BISHOP OF BARBADOS, 25. Parson, so.

Parson. ANonymous, 80 ; Eliz., 74 ; Isabella. $80 ;$ JOHs, 80.
Parsons, 26,73, so.

Parsons, DANiEL, 25 (2), 26; EDWARD, 80 ; Rev. John, 26 ; Nath., 73.

Partington, 87 .

Partington, 'THos. WALLEY, 87 .

Partridge, Sybella, 45 .

Payne, 75, 80, 81, 82

Payne, Eliz., 75 ; Maria Mary, 81 ; Mary, 74 ;

Sir Peter, 81 ; RALPH, 80 ; RALPH, BARON

LAVINGTON, 81.

Pearee, 74.

Pearce, Charles, 74; Eliz, Philadelphia, 74.

Pearne, Eliz., 10

Ped.der, 59 .

Pedder, JAMES, 59 (2).

Pemberton, 69.

Pemberton. R. Boileau, 69 ; R. C. B., 70.

Penn, Sophia, 23.

Pennant, 60.

Pennant, EDWARD GordoN DOUGLAS, 60 ;

Mar'y Louise, 60.

Penny, 86.

Penny, Edward LeWTON, 86

Penrhyn, BdroN, 60 ; Mary Louise, Lady, 60.

Pérot (Perrot), JAMEs, 29.

Perry, 61.

Perry, John, 61 ; IIary, 61 ; Sarah, 7.

Phillimore, --, 86

Phillips, 27.

Phipps. 91.

Phipps, H. R., 87 ; LUкE Rocнe, 82 ; Martha 42 ; Lt..CoL. P., 81 (2); Sophia Matilda, $81 ; \mathrm{Wm}^{\top}, 82$.

Pinder, 26.

PINDER, 26 ; REV. JoHN Hoth ERSALL, 26.

Pinfold, 26.

Pinfold, ARabella, 26 ; Chas., 26 (3); Rev.

C. J., 26 ; Louisa, 26; Renea, 26.

Pinney, 70

Pinney, Charles. 70; Eliz., 70; Јонм, 70 ; JOHN CHARLES, 70 .

Pinnoek, 41.

Pinnock, Eliz., 41 ; Louisa, 41 ; Mary, 47 ; Philip, 41 ; Thomas, 47 .

Polak, - 32 .

Pole, Mary, 35.

Pollexfen, 12.

Pontifex. Russell, 13 ; William, 13.

Pook. H. W., 76 .

Pott. Sarah, 67.

Ponel, Prinee of Caerleon, 4.

Poyntz, 31, 60.

Poyntz, Hannah, 60 ; Joseph, 60.

Preisig, 66.

Prescott, George WILLIAM, 56 ; Sarah, 56.

Pieston, 40.

Pretor, 70.

Pretor, John, 70.

Prevost, 39.

Prevost, Anne Margaret, 39.

Proetor, 2, 37 .

Proctor, Katherine, 37 ; Mary, 2 ; Metcalfe, 37.

Pulsford, Rev. C. H., 65 ; Letitia 'Sarah, 65.

\section{$\mathrm{R}$}

Rae (?), 31 .

Ramsay, 12.

Rawdon, Iarm., 88.

Rawlins, Frances, 72. 
Reade, 49.

Reade. Caroline Charlotte, 49 ; Florence Jane, 49 ; Philip Villiers. 49.

Rennell, Sarah Eliz., 21.

Reynolids. 26.

Reynolds, FrANCIS, 26.

Rice, JoHN, 27.

Richardson, 20

Rickets, 60 .

Ricketts, Lady Eliz. Jane, 60 ; George Crawford. 60: George Poyntz, 60; George Poyntz,

jun.. 60: GEo. WILL.. 60 ; Sir Henry. 60;

Jas., 53 ; Mary, 60 ; MoRdaUNT, 60 ; MIRs.

PoyNTz, 60; Sophia. 60 (2); Will. HeN., 60 (3).

Righy, 60)

Rigby. Framces, 60 ; Francis HALE, 60, 61 ; Martha, 61 : Rich., 61.

Roberdeau, 81 .

Roberdeau, DAniel, 81 ; John Peter, 81.

Roberts, Jane, $7 \pm$; John, 74.

Robertson, 61 .

Robertson, EBEN., 61 (2).

Robinson, 27.

Robinson. Eliz., 27; Thomas, 27; SIR THos.; $27 ;-27,29$.

Rokebr Lord 46 .

Rose, Eliz., 62 ; Gro., 13 (2), 14 (2); Fulke, 62 ; Theodora, 13.

Ross. 13.

Ross. MarJ, 13 ; John, 13.

Rone, 61 .

Rowe, Frances Ann, 61 ; SIR JoshuA, 61.

Royall, it.

Royall, Elizabeth, 14: ISAAC, 14

Rumbold, Sir Tho,, 61 .

Russell, 75.

Russell, Emily Anne, 75; Sir Robert Frankland, 75 .

Rutherford, $1 t$.

Rutherford. Јон上, 14.

\section{S}

Sage, Charles Fred., 27 ; William Hood, 27.

St. John, Lord, 22 ; Mary, 22.

St. Leger. 6.

St. Leger. Anthony, 6.

St. Hanr, 55 .

St. Vincent. John, Earl. 60.

Salmon. Sam., $27 ;-, 27$.

Salmond. Eliz.. 14; Jane, 14; Wu., 14.

Salter, 27.

Salter, Michard, 27.

Sanders. 70.

Sanders, Fra.. jun., 70; Fraxcis Williams, 70 (2); J. IV., 70 ; Martha, 70.

Scarborough, Richard, Earl of, 29; see also Lumley.

Soarlett, 61 .

Sehan, 61 .

Schaw, dLEx., 61 ; Jen, 61

Seholey, 48.

Seott, 3, 9, 16, 27, 61

Scott, BenJAMIN, 61 ; Eliz., 3, 16 ; Eliz. Favell, 41 ; M. H., 41 ; RICHARD, 3, 27.

Seotland, 14 .

Scotland, Јонм, 14

Selby, Elinora. 68 ; Thos., 68.
Sererne, 32.

Severne, SAJUEL AMY, 32.

Sewell, Anua Maria, 54; Sir Tho.. 54.

Shatespear, 61.

Shakespear, Ann, 37 ; Cath., 61 ; DAvID, 61 ; Johil. 37.

sthand. 31 .

Shawe, Mary Ann, 14.

Shipley, 15.

Shipley, Cath. Jane Mathew, 16 ; Sir Charles, 16.

SIERRA IEONE, BISHOP OF, 20.

Simmons, 61.

Simmons, IIary, 61 ; THomá FredericK, 61.

Simpson. Eliz.. 6i ; John, $6 \pi$.

Sinckler, E. G.. 86; Mrs., 86 .

Skecte, 20

Skeete, Agnes, 20 ; John Brathwaite, 20.

Skinner, J., 44.

Skipwith. 56 .

Skottowe, Eliz., 6.

Slanning. 48 .

Sligo, 52.

Sligo, Browxt, MARQuess of, 52; Howe Peter, Marquess of, 52 ; Hester Cath., Marchiouess, 52 .

Sloane, 62.

Sloane, Eliz., 62 ; HAxs, 62 ; Sir Hans, 62 ; Sarah, 62 ; Wm., 62 .

Smith. 70, 76, 77, 78 .

Smith. Ann. 77 : Daniel. 73. 77 : Ellen, 76 ; J. 33 ; JAMES BogLE, 14 ; John, 14, 13 ; Mary, 8, 14; MIary Ann. 14; Penelope. 73, 78; Rebecca, 14: RowLAND, 14; W.. 28; WILIIAJ, 70,$75 ;-\ldots, 28$.

Smyth. 33

Smyth, SiR JAMES CARMICHAEL, 33.

Snagg, 83.

Snagg, Anne, 83 : Williad, 83.

Sober. 27.

Sober, JoH, 27.

Solomons, $J, 43$

Somerset, 58 .

Somerset. Lady Henrietta Louisa, 5s ; see also Beaufort.

Soulegre. 79 .

Soulegre, Cornelia, 79 : Peter, 79.

Spence, Pat., 53; Sarah Brissett, 53

Spencer, ANoxysious. 62: AUBREY. Bishop of Jamaica, 62 ; AUBREY, Bishop of Newfoundland, 62 ; AUBREY GEO., 62 ; AUBREY G., Archdeacon of Bermuda, 62 ; BisHoP, 62.

Spire, 19.

Spooner: 81.

Spooner, CHARLes, 81 ; Mary, 81.

Spry. 2 S.

Spry, Cath.. 28 ; Dr. E.. 28 ; Horatio, 28 ; Jane, 28: Jeffry, 88; John, 88; Mary, 2S; WILLIAM, 28.

Stane, 36.

Starkic, 77,78

Stephens, Anne, $51 ;-, 3$.

Stewart, 29, 73.

Stewart, DuxcAx, 29 ; Maxy, 1 t.

Stokes. 19.

Stokes, ANTHONY, 19.

Storer, 62.

Storer, ANowymous, 62 ; Anthony, 62 ; Anthony Morris, 62; Cicely Barr, 62; Eliz. Anna Maria, 62.

Stratheden, Baroness, 61 ; see also Campbell. 
Strickland, 24, 75.

Strickland, Eliz., 75 ; Sir George, 75.

Sturges, s.

Sturges, Frauces, 8

Suffield. - 25, 29.

Sutherland, Mary, 29.

Sivete, 14.

Swete, ADRIAN JoHs, 14 : MIain, 14.

Sivymmer, 62.

Swymmer, Aутнолy LANGLEY, 62 ; Arabella,

62.

Sydserf, 14 .

Sydserf, JoH:, 15 ; WALTER, 14.

Symes, 62.

Symes, Wуг. LeIGH, 62.

Syms, 68.

Syms, Geo., 68 ; Henry; 68 ; Richard, 63.

Talbot, Chas. Tho., 49 ; Julia, 49.

Tate. $55,56$.

Tayloi, 39, 63

Taylor, Anonymods, 63 ; E., 63 ; Eliz., 17 J., 63 (3) ; SIR J., 63 ; Sir John, 63 ; LADY, 63 ; SIMON, 63 ; SIR SIMON, 63 ; SIR SIMON R. B., $63(2) ;-63$.

Territt, 29

Territt, Anne Cath., 29 ; WM., 29.

Tesehemaker, 34

Teschemaker, JoHN, 34 .

Tetlow, t8.

Thomas, 15.

Thomas, Sir Geo., 15 ; Lydia, 15 ; Margaret,

15 ; Sir $1 \mathrm{Vm} ., 15$.

Thomlinson, 55.

Thomlinson, John, 54 (2) ; Mary, 54 .

Thompson, 9, 85 .

Thompson, ELEANoR, 85 ; J., 23 ; - 63.

Thomson, 63

Thomson, DAvid, 63.

Thornton, 86.

Thornton, JoHN, 86.

Thur.gar, +1 .

Tichborne, Sir Henry, 49 ; Julia, 49.

Tobin, 71 .

Tobin, Geo., 71 ; JAs., 70.

Tollemaohe, 7 .

Tollemache, Lady Jane, 7.

Toms. IV. H., 66.

Townley. 81.

Townley, Hexry WARD, 81 .

Trant, 68.

Trant, DoMINICK, 68

Trotman, 49

Trotman, Fiennes, 49 ; Hester Louisa, 49.

Trower, Dorothy, 38 ; Eliz. Savile, 38.

Tucker, 5 5.

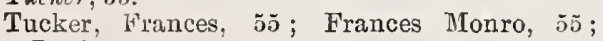
Lucius, 55.

Tudway, 15.

Tudway, Charles Clement, 15.

Tuite, bis.

Tuite, ElinorA, 68 ; Sir Jos., 68; Nich., 68 ; ROBERT, lis.

Tullideph, 15.

Tullideph. Charlotte, 12 ; David, 15 ; Thomas, 15 ; WaIter, 12,15

Tunckes, 28.
Tunckes, Kath., 28; Thomas, 28.

Turner, Anne, 83; John, 83.

Tryning, 6 r.

Twyning, IVm., 64; Williast HeNrY, 64.

rany. 32 .

Udny, ALEXANDER, 32; Ernest, 32 ; J. H., 32; James, 32; John Rob. Fullarton, 32: Hary, 32 : Rob. Fullarton, 32.

$\nabla$

L'an Leenuput, $77,78(7)$.

Trasiall, $\dot{01}, 65$.

Vassall, Anne, 6t; DR., 6t; Eliz., 18, 6t, 65; FANYY, 6t; Honor Mary Georgiana, 65; Jонs, 64 (2) ; RAwDoN J. P., 64 ; Richard, 65 ; SPENCER, 64; SPENCER L. H., 64, 65 ; Spencer Tho., 65; IVILLIAM, 64.

Vauyluan, 65, 77.

Vaughan, BeNJAuIs, 65, 77 ; Dorothea, 35 ; SAJUEL, 65 (2) ; Sarah, 65 ; William, 65.

Vernon, 65.

Vernon, Bowater, 65 ; HenRy GARRIOCH, 65.

Ton Geyer, 31.

IV

Wralker, 32.

Walker, Anna, 32 ; Sik Geo. Towxshend, 32

Haller, š3.

Walroud, 15.

Walrond, Caroline Maud, 15 ; HeNRY, 15.

Walter, 23, 27, 86 .

Walter, Abel, 86 ; How. Mrs., 86.

TVard, James, 81 ; Townley, 81.

Warner, 3, 9, 15, 16.

Warner, Ashton, 84; Edward, 3, 9, 15, 16; Eliz., 3, 15 ; Eliz. Anne, 9 ; FredericK, 81 ; Grace, 3, 4, 16; Jane, 3; Rachell, 28; Wм., 15

Warren, 37.

Warren, Sir John Borlase, 29 ; Priscilla, 2 ; Robert. 2.

Warwiek, - $44,70,75$.

Wastington, 53.

Waterman, THos., 28.

Watkins, 12.

Watkins, Frances, $\tilde{0}$

Watson, 63, 72 .

Watson, Anna Susanna, 63 ; Geo., 63.

Vatts, Governor, 60 ; Sophia, 60.

We $b b, 68,69$.

Webb (Webbe), Јон, 68 ; John Spencer, 68 ; Mary, 69 (2); N., 68; Nathaniel, 68 (2), 69 ; Robert, 69; Ruth, 69 ; MRs. SPENCER, 68 .

Webber, Rev. A., 87 ; Jane, 87.

II custer. 81.

Webster. Eliz., 65 ; Sir Godfrey, 65 ; JosEPH, 81 ; Maria Mary, 81.

Trediderburn, 65 .

Wedderburn, JA JIES, 65. 
Weches, 28.

Weekes, Nathaniel, 28 ; Ralph, 28; Rebecca Ann, 28.

Wegg. EDHUND Rosh, 19

Weleh, 66 .

Welch, LuCretia FAvell, 66 ; Richard, $66^{\circ}$; T., 3 i.

We]sh, Jane Akers, 3.

West, E. E., 42, 43 .

Wharton, 81.

Wharton, ANTHONY, 81 ; ТномAs, 81 .

Wheeler', 81.

Wheeler, THos. LuCAs, 81.

White, Anne, 66 ; Dorothea Susa, 66 ; John, 66 (2); Wm., 66.

Whitehead, 16.

Whitehead, Jane, 16 ; WM., 16.

Whitehouse, Fanny, 30.

Wigglesworth, JoHN, 66.

Wildman, CoL.: 66.

Willett, 82.

Willett, Eliz. St. Leger, 74; HExRY RALPH, 82: John, 74

Williams, $16,66,75,77$.

Williams, EDWARD, 16 ; GERSHOI. 66, 88; Martha, 70; RowlaND EDWARD, 16 ; Thomas, 16; Wм., 16, 66 .

Willing (?), 85 .

Willis, 16.

Willis. Benkdict, 16 ; Joseph Webb, 17 ; Mary, $16 ; \mathrm{WEBB}, 17$.

Willoek, 17.

Willock, CHARLES W., 17.

Willoughby. Cicely Barr, 62 ; Sir John Pollard, 62.

Wilmot, 12.

Wilmot, Elizabeth, 12.

Wilson, 28.

Wilson, D., and Co., 66 ; JoHN, 28, 66 ; PETER, 28 ; THOMAs, 84.

Wollaston, 4, 80 .

Wollaston, Charlton, 4 ; Charlton Bxam, 4 ; Frederick, 80 ; Phillis, 4 ; Priscilla, 80 ; Wm.. 80.

Woodbridge, 28.

Woodbridge, Dudury, 28 ; Rev. Dudley, 28 ; Ruth, 28.

Woodley, 71, 73 .

Woodley, JoH, 71

Toolward. 71 .

Woolward, Frances Herbert, 71 ; Wm., 71.

Wylly, Alex., 83 ; Campbell, 83 ; Winliai, 19 (2), $83,88$.

Wron, B., 24, 25, 34, 62, 65 .

Yute, 5.

$\mathrm{Y}$

Yate, Caroline Elizabeth Dobyns, 5.

Yeamans, Eliz. Rachel Anne, 10; John, 10 ; Mar'y, 10.

Yeo, John, 30 ; Thomas, 30 (2).

Iorke, 11, 66 .

Yorke, Charlotte, 11 ; Col., 11 ; ЈонN, 66.

Young, 17.

Young, Sir Charles Laurence, 17 ; Eliz., 17 ; JoHN, 17 (2) ; Sarah, 17 ; WILLIAM, 17 ; SIR WM., 17 (2), 33, 84 .

Zouelue, 55, 56 .
Z 
